USGS National Water Census and National Streamflow Information Program

\title{
Methods for Estimating Water Consumption for Thermoelectric Power Plants in the United States
}

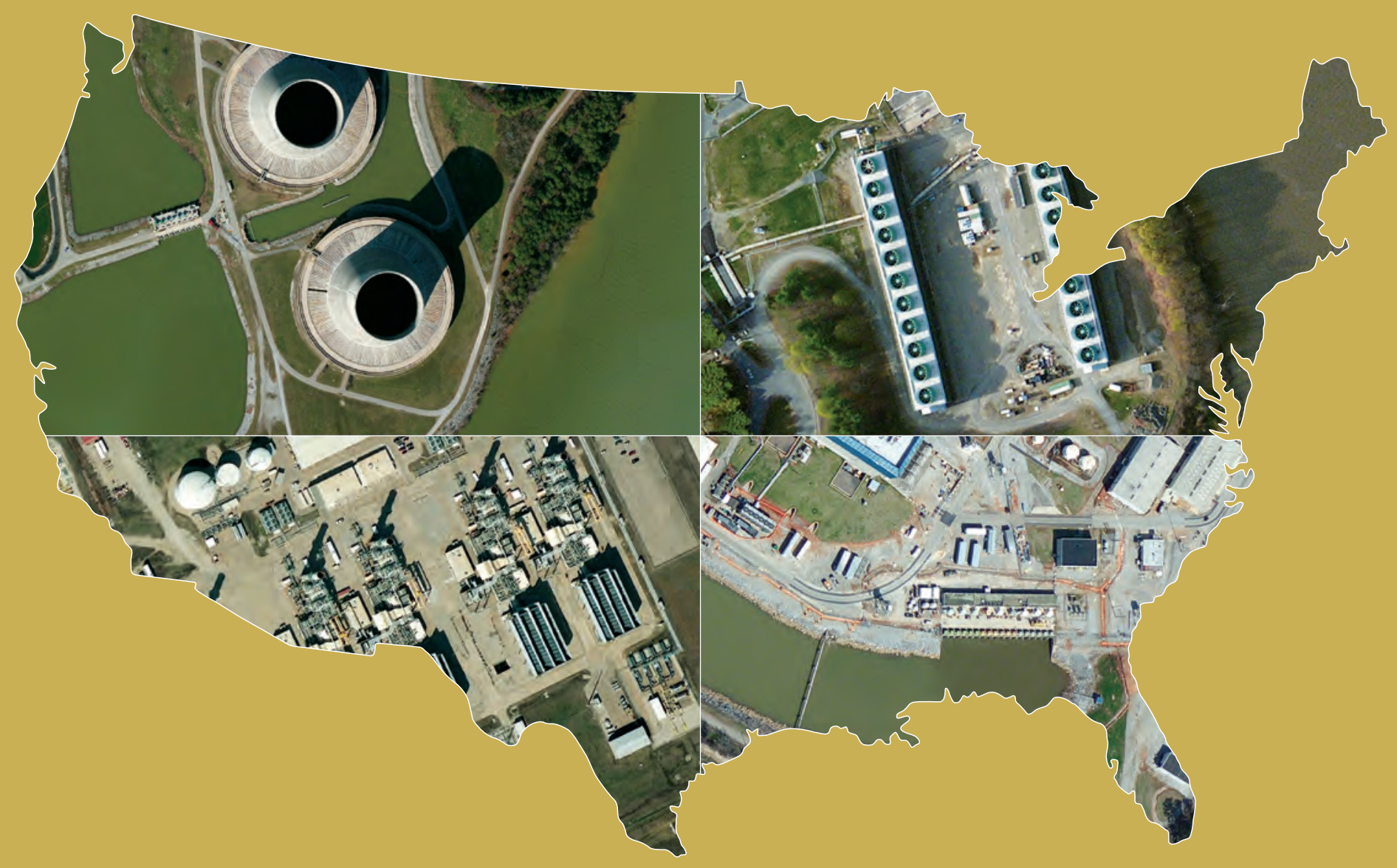

Scientific Investigations Report 2013-5188

U.S. Department of the Interior U.S. Geological Survey 
Cover. Aerial photographs of thermoelectric power plants in the United States from the U.S. Department of Agriculture (USDA) National Agriculture Imagery Program (NAIP), 2007. Refer to figures 2, 3, 5, and 6. 


\section{Methods for Estimating Water Consumption for Thermoelectric Power Plants in the United States}

By Timothy H. Diehl, Melissa A. Harris, Jennifer C. Murphy, Susan S. Hutson, and David E. Ladd

USGS National Water Census and National Streamflow Information Program

Scientific Investigations Report 2013-5188 


\title{
U.S. Department of the Interior SALLY JEWELL, Secretary
}

\section{U.S. Geological Survey Suzette M. Kimball, Acting Director}

\author{
U.S. Geological Survey, Reston, Virginia: 2013
}

For more information on the USGS - the Federal source for science about the Earth, its natural and living resources, natural hazards, and the environment, visit http://www.usgs.gov or call 1-888-ASK-USGS

For an overview of USGS information products, including maps, imagery, and publications, visit http://www.usgs.gov/pubprod

To order this and other USGS information products, visit http://store.usgs.gov

Any use of trade, product, or firm names is for descriptive purposes only and does not imply endorsement by the U.S. Government.

Although this report is in the public domain, permission must be secured from the individual copyright owners to reproduce any copyrighted materials contained within this report.

Suggested citation:

Diehl, T.H., Harris, M.A., Murphy, J.C., Hutson, S.S., and Ladd, D.E., 2013, Methods for estimating water consumption for thermoelectric power plants in the United States: U.S. Geological Survey Scientific Investigations Report 2013-5188, 78 p., http://dx.doi.org/10.3133/sir20135188. 


\section{Contents}

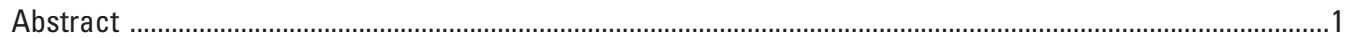

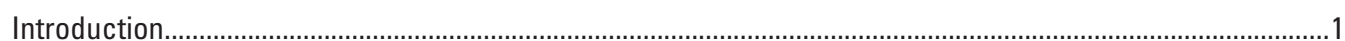

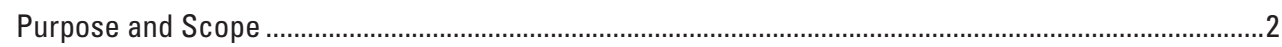

A Heat Budget Approach to Thermoelectric Water Consumption ......................................................................2

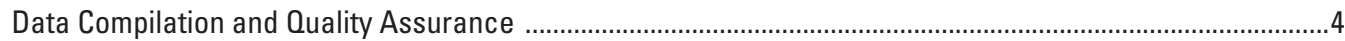

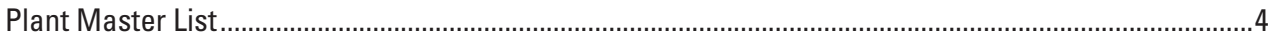

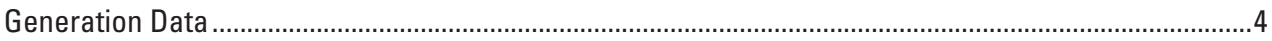

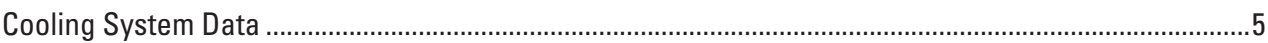

Power Plant Locations and Elevations.........................................................................................

Cooling-System Type Validation ...............................................................................................

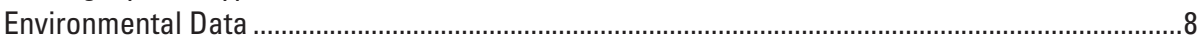

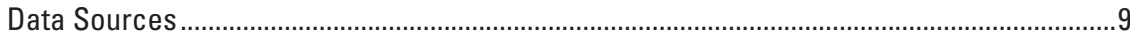

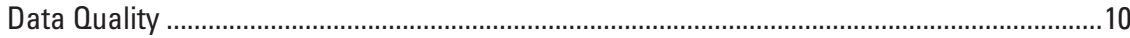

Methods of Determination for Environmental Input Variables..................................................

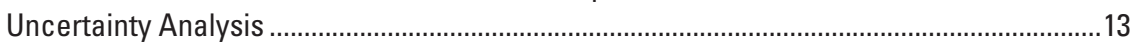

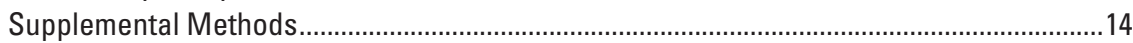

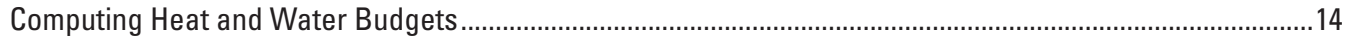

Estimation of Condenser Duty by Generation Type .............................................................................

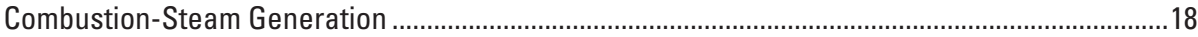

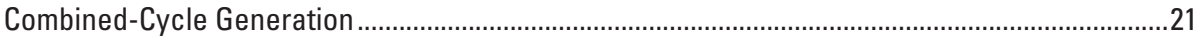

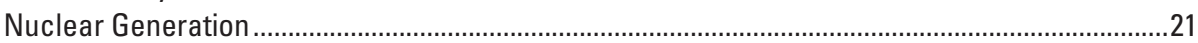

Geothermal Generation ..........................................................................................................22

Estimating Thermoelectric Evaporation by Cooling-System Type...........................................................23

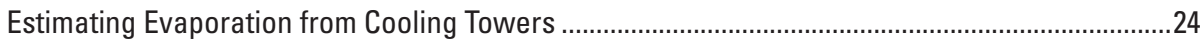

Estimating Forced Evaporation from Surface Water ...................................................................2

Error Analysis and the Prediction of Maximum and Minimum Likely Consumption.................................28

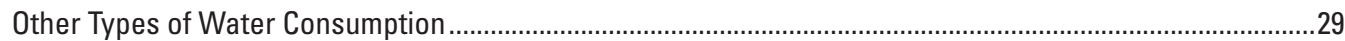

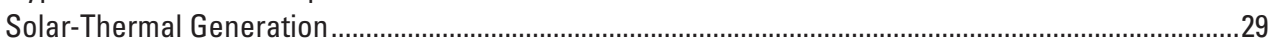

Flue-Gas Desulfurization..................................................................................................................29

Minor Water Consumption at Combined-Cycle Plants........................................................................29

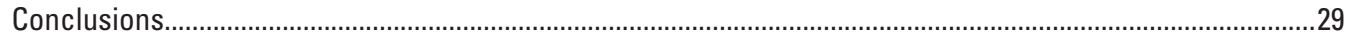

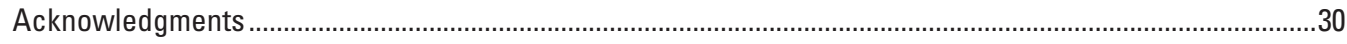

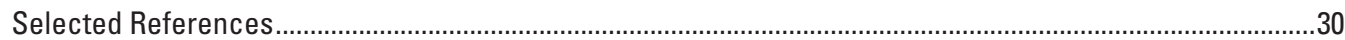

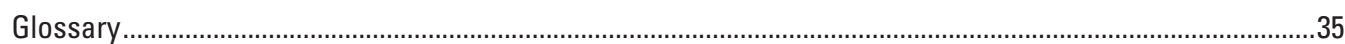

Appendix 1: The 1,284 thermoelectric plants one megawatt nameplate capacity or

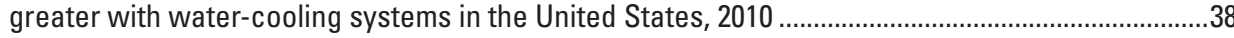

Appendix 2: Guide to data contained in the U.S. Department of Energy, Energy Information Administration (EIA) 2010 Annual Electric Generator Data, Form-860, and the 2010 Power Plant Operations Report, Form ElA-923, used for the classification of thermoelectric plants and consumption estimation model input.

Appendix 2. Table 1: Data used in the two-tiered classification system for thermoelectric plants and heat and water budget models to estimate water consumption from the 2010 Annual Electric Generator Data, EIA Form-860 and 2010 Power Plant Operations Report, Form EIA-923.

Appendix 2. Table 2: Prime mover types used to classify plants according to

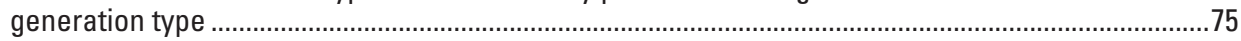

Appendix 2. Table 3: Energy sources used to classify plants by generation type ..........................................76

Appendix 2. Table 4: Cooling-sytem types used to classify plants by cooling system technology......

Appendix 3: Databases accessed for thermoelectric plant classification and modeling data

Appendix 4: Forced Evaporation from Water Surface (FEWS) spreadsheet............................. available online in an Excel file at http://pubs.usgs.gov/sir/2013/5188/appendix/sir2013-5188_appendix4_fews_ version_3.104.x/sx 


\section{Figures}

1. Map showing geographic distribution of the 1,284 thermoelectric plants one megawatt nameplate capacity or greater with water-cooling systems in the United States, 2010.

2. Aerial photograph showing natural-draft cooling towers and one of two intake screens and associated pumps for the Tennessee Valley Authority, Sequoyah Nuclear Power Plant, Tennessee...

3. Aerial photograph showing mechanical induced-draft cooling towers (wet cooling towers) and the discharge outlet for Entergy Vermont, Vermont Yankee Nuclear Power Plant, Vermont.

4. Aerial photograph showing a mechanical forced-draft tower for the Arvah B. Hopkins Power Generating Station, Florida.

5. Aerial photograph showing dry cooling towers for the Midlothian Power Plant, Texas. 10

6. Aerial photograph showing intake screen and pumps used for once-through cooling at the Browns Ferry Nuclear Plant, Alabama.

7. Aerial photograph showing the approximately 2.5-mile-long cooling pond for the Lewis Creek Generating Plant, Texas.

8. Aerial photograph showing the approximately 8-mile-long cooling-water reservoir for the Lieberman Power Plant, Louisiana 13

9. Graph showing the distribution of cooling-water types for modeling evaporation for 1,284 thermoelectric plants

10. Map showing geographic distribution of the 554 weather stations containing 12 months of monthly mean dry bulb and wet bulb temperatures in 2010 15

11. Map showing geographic distribution of the 727 weather stations containing 12 months of monthly mean wind speed in 2010 ..... 16

12. Map showing geographic distribution of the $\mathbf{7 5 5}$ water temperature stations (U.S. Geological Survey stations and greater than 100 megawatt power plants reporting intake temperature) with at least one month of monthly mean water temperature in 2010

13. Sankey diagram for an example combustion steam power plant with combined heat and power

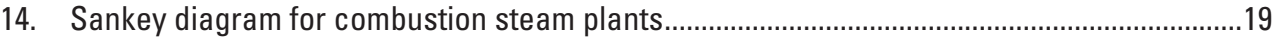

15. Sankey diagram for combined cycle plants ........................................................................22

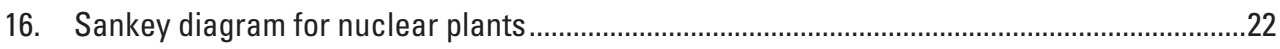

17. Sankey diagram for geothermal plants ............................................................................23

18. Graph showing evaporation ratio in relation to wind speed, estimated using Brady and others (1969) wind function.

19. Graph showing evaporation ratio in relation to wind speed at 20 degrees Celsius for four selected wind functions

20. Graph showing effect of pond heat loading on evaporation ratio..... .28

\section{Tables}

1. Generation-type classification categories used to estimate condenser duty .3

2. Cooling-system type classification categories used to estimate evaporation.

3. Boiler efficiency, reported fuel heat, and estimated fuel heat by fuel type for combustion steam plants 


\section{Conversion Factors and Datum}

\begin{tabular}{|c|c|c|}
\hline Multiply & By & To obtain \\
\hline \multicolumn{3}{|c|}{ Length } \\
\hline kilometer (km) & 0.6214 & mile (mi) \\
\hline mile (mi) & 1.609 & kilometer $(\mathrm{km})$ \\
\hline \multicolumn{3}{|c|}{ Area } \\
\hline acre & $4,047.0$ & square meter $\left(\mathrm{m}^{2}\right)$ \\
\hline acre & 0.4047 & hectare (ha) \\
\hline acre & 0.4047 & square hectometer $\left(\mathrm{hm}^{2}\right)$ \\
\hline acre & 0.004047 & square kilometer $\left(\mathrm{km}^{2}\right)$ \\
\hline square centimeter $\left(\mathrm{cm}^{2}\right)$ & 0.001076 & square foot $\left(\mathrm{ft}^{2}\right)$ \\
\hline square centimeter $\left(\mathrm{cm}^{2}\right)$ & 0.1550 & square inch $\left(\mathrm{ft}^{2}\right)$ \\
\hline square meter $\left(\mathrm{m}^{2}\right)$ & 0.0002471 & acre \\
\hline square meter $\left(\mathrm{m}^{2}\right)$ & 10.76 & square foot $\left(\mathrm{ft}^{2}\right)$ \\
\hline \multicolumn{3}{|c|}{ Volume } \\
\hline gallon (gal) & 3.785 & liter $(\mathrm{L})$ \\
\hline gallon (gal) & 0.003785 & cubic meter $\left(\mathrm{m}^{3}\right)$ \\
\hline gallon (gal) & 0.1337 & cubic foot $\left(\mathrm{ft}^{3}\right)$ \\
\hline liter $(\mathrm{L})$ & 33.82 & ounce, fluid (fl. oz) \\
\hline liter $(\mathrm{L})$ & 2.113 & $\operatorname{pint}(\mathrm{pt})$ \\
\hline liter $(\mathrm{L})$ & 1.057 & quart (qt) \\
\hline liter $(\mathrm{L})$ & 0.2642 & gallon (gal) \\
\hline liter (L) & 0.0353 & cubic foot $\left(\mathrm{ft}^{3}\right)$ \\
\hline \multicolumn{3}{|c|}{ Mass } \\
\hline gram $(\mathrm{g})$ & 0.03527 & ounce, avoirdupois (oz) \\
\hline gram (g) & 0.0022 & pound, avoirdupois (lb) \\
\hline kilogram (kg) & 35.27 & ounce, avoirdupois (oz) \\
\hline kilogram (kg) & 2.205 & pound, avoirdupois (lb) \\
\hline \multicolumn{3}{|c|}{ Density } \\
\hline gram per cubic centimeter $\left(\mathrm{g} / \mathrm{cm}^{3}\right)$ & 62.4220 & pound per cubic foot $\left(\mathrm{lb} / \mathrm{ft}^{3}\right)$ \\
\hline \multicolumn{3}{|c|}{ Pressure } \\
\hline Bar & 100 & kilopascal (kPa) \\
\hline Millibar & 0.1 & kilopascal (kPa) \\
\hline \multicolumn{3}{|c|}{ Energy } \\
\hline British thermal unit (Btu) & $1,055.06$ & joule $(\mathrm{J})$ \\
\hline British thermal unit (Btu) & 252 & calorie (cal) \\
\hline British thermal unit (Btu) & 0.0002931 & kilowatthour (kWh) \\
\hline calorie & 4.184 & joule $(\mathrm{J})$ \\
\hline joule (J) & 0.2390057 & calorie (cal) \\
\hline joule (J) & 0.0000002 & kilowatthour (kWh) \\
\hline kilowatt hour (kWh) & $3.6 \times 10^{6}$ & joule $(\mathrm{J})$ \\
\hline kilowatt hour (kWh) & $3,412.14$ & British thermal unit (Btu) \\
\hline megawatt (MW) & $1.0 \times 10^{6}$ & joule per second $(\mathrm{J} / \mathrm{s})$ \\
\hline megawatt (MW) & $8.6 \times 10^{8}$ & calories per hour $(\mathrm{cal} / \mathrm{h})$ \\
\hline megawatt hour (MWh) & $3.6 \times 10^{9}$ & joule $(\mathrm{J})$ \\
\hline megawatt hour (MWh) & $3.4 \times 10^{6}$ & British thermal unit (Btu) \\
\hline $\begin{array}{l}\text { million British thermal unit } \\
(\text { MMBtu })\end{array}$ & $1.055 \times 10^{9}$ & joule $(\mathrm{J})$ \\
\hline
\end{tabular}




\begin{tabular}{|c|c|c|}
\hline Multiply & By & To obtain \\
\hline \multicolumn{3}{|c|}{ Rate } \\
\hline $\begin{array}{l}\text { calorie per centimeter squared } \\
\text { degrees Kelvin per day } \\
\left(\mathrm{cal} / \mathrm{cm}^{2 \circ} \mathrm{K} / \mathrm{d}\right)\end{array}$ & 0.484259 & $\begin{array}{l}\text { kilogram degrees kelvin per cubic } \\
\text { second }\left(\mathrm{kg}^{\circ} \mathrm{K} / \mathrm{s}^{3}\right)\end{array}$ \\
\hline $\begin{array}{l}\text { calorie per centimeter squared per } \\
\text { second }\left[\mathrm{cal} /\left(\mathrm{cm}^{2} / \mathrm{s}\right)\right]\end{array}$ & 41,840 & watts per meter squared $\left(\mathrm{W} / \mathrm{m}^{2}\right)$ \\
\hline calorie per gram $(\mathrm{cal} / \mathrm{g})$ & 4,184 & joule per kilogram $(\mathrm{J} / \mathrm{kg})$ \\
\hline $\begin{array}{l}\text { calorie per gram degrees Kelvin } \\
\left(\mathrm{cal} / \mathrm{g}^{\circ} \mathrm{K}\right)\end{array}$ & 4,184 & $\begin{array}{l}\text { joule per kilogram degrees Kelvin } \\
{\left[\mathrm{J} /\left(\mathrm{kg}^{\circ} \mathrm{K}\right)\right]}\end{array}$ \\
\hline gallon per kilowatt hour (gal/kWh) & $1.0515 \times 10^{-6}$ & liter per joule $(\mathrm{L} / \mathrm{J})$ \\
\hline gallon per kilowatt hour (gal/kWh) & $4.3995 \times 10^{-6}$ & liter per calorie (L/cal) \\
\hline $\begin{array}{l}\text { gallon per megawatt hour } \\
\text { (gal/MWh) }\end{array}$ & $1.0515 \times 10^{-9}$ & liter per joule $(\mathrm{L} / \mathrm{J})$ \\
\hline $\begin{array}{l}\text { gallon per megawatt hour } \\
\text { (gal/MWh) }\end{array}$ & $4.3995 \times 10^{-9}$ & liter per calorie (L/cal) \\
\hline megawatt per acre (MW/acre) & 0.0059 & $\begin{array}{l}\text { calorie per square centimeter per } \\
\text { second }\left[\mathrm{cal} /\left(\mathrm{cm}^{2} / \mathrm{s}\right)\right]\end{array}$ \\
\hline mile per hour $(\mathrm{mi} / \mathrm{h})$ & 1.60934 & kilometer per hour $(\mathrm{km} / \mathrm{h})$ \\
\hline
\end{tabular}

Temperature in degrees Celsius $\left({ }^{\circ} \mathrm{C}\right)$ may be converted to degrees Fahrenheit $\left({ }^{\circ} \mathrm{F}\right)$ as follows: ${ }^{\circ} \mathrm{F}=\left(1.8 \times{ }^{\circ} \mathrm{C}\right)+32$

Temperature in degrees Fahrenheit $\left({ }^{\circ} \mathrm{F}\right)$ may be converted to degrees Celsius $\left({ }^{\circ} \mathrm{C}\right)$ as follows:

$$
{ }^{\circ} \mathrm{C}=\left({ }^{\circ} \mathrm{F}-32\right) / 1.8
$$

Temperature in degrees Kelvin $\left({ }^{\circ} \mathrm{K}\right)$ may be converted to degrees Celsius $\left({ }^{\circ} \mathrm{C}\right)$ as follows:

$$
{ }^{\circ} \mathrm{C}=\left({ }^{\circ} \mathrm{K}-273.15\right)
$$

Temperature in degrees Kelvin $\left({ }^{\circ} \mathrm{K}\right)$ may be converted to degrees Fahrenheit $\left({ }^{\circ} \mathrm{F}\right)$ as follows:

$$
{ }^{\circ} \mathrm{F}=\left(\left({ }^{\circ} \mathrm{K}-273.15\right) \times 1.8\right)+32
$$

Vertical coordinate information is referenced to the North American Vertical Datum of 1988 (NAVD 88).

Elevation, as used in this report, refers to distance above the vertical datum.

\section{Abbreviations}

$\begin{array}{ll}\text { Btu } & \text { British thermal units } \\ \text { CPPDB } & \text { Coal Power Plant Database } \\ \text { DEM } & \text { Digital Elevation Model } \\ \text { ECHO } & \text { USEPA database, Enforcement and Compliance History Online } \\ \text { eGRID } & \text { Emission and Generation Resource Integrated Database } \\ \text { FERC } & \text { Federal Energy Regulatory Commission } \\ \text { FGD } & \text { Flue-gas desulfurization } \\ \text { GIS } & \text { Geographic Information System } \\ \text { GLERL } & \text { Great Lakes Environmental Research Laboratory }\end{array}$




$\begin{array}{ll}\text { GLSEA2 } & \text { Great Lakes Surface Environmental Analysis } \\ \text { HRSGs } & \text { Heat-Recovery Steam Generators } \\ \text { HSIP } & \text { Homeland Security Infrastructure Program } \\ \text { ICIS } & \text { Integrated Compliance Information System } \\ \text { kWh } & \text { Kilowatt hour } \\ \text { L/G } & \text { Mass ratio of water flow to dry air flow in a cooling tower } \\ \text { MMBtu } & \text { Million British thermal units } \\ \text { MW } & \text { Megawatt } \\ \text { MWh } & \text { Megawatt hour } \\ \text { MWhe } & \text { Megawatt hour electric } \\ \text { NAICS } & \text { North American Industry Classification System } \\ \text { NEEDS } & \text { National Electric Energy Data System } \\ \text { NETL } & \text { National Energy Technology Laboratory } \\ \text { NHDPlus } & \text { National Elevation Dataset, Horizon Systems Corporation } \\ \text { NOAA } & \text { National Oceanic and Atmospheric Administration } \\ \text { NOx } & \text { Nitrogen Oxides } \\ \text { NPDES } & \text { National Pollutant Discharge Elimination System } \\ \text { PCS } & \text { Permit Compliance System } \\ \text { OCLCD } & \text { Quality Controlled Local Climatological Data; also LCD } \\ \text { USEIA } & \text { U.S. Energy Information Administration; also EIA } \\ \text { USEPA } & \text { U.S. Environmental Protection Agency; also EPA } \\ \text { USGS } & \text { U.S. Geological Survey }\end{array}$





\title{
Methods for Estimating Water Consumption for Thermoelectric Power Plants in the United States
}

\author{
By Timothy H. Diehl, Melissa A. Harris, Jennifer C. Murphy, Susan S. Hutson, and David E. Ladd
}

\section{Abstract}

Water consumption at thermoelectric power plants represents a small but substantial share of total water consumption in the U.S. However, currently available thermoelectric water consumption data are inconsistent and incomplete, and coefficients used to estimate consumption are contradictory. The U.S. Geological Survey (USGS) has resumed the estimation of thermoelectric water consumption, last done in 1995, based on the use of linked heat and water budgets to complement reported water consumption. This report presents the methods used to estimate freshwater consumption at a study set of 1,284 power plants based on 2010 plant characteristics and operations data.

Power plants were categorized for estimation of water consumption in two tiers. First, generating units were assigned to categories based on the technology used to generate electricity. These generation-type categories are combustion steam, combined-cycle, nuclear, geothermal, and solar thermal. Second, cooling systems were separately categorized as either wet cooling towers or surface-water cooling systems, and the surface-water cooling systems were subcategorized as cooling ponds, lakes, and rivers.

Heat budgets were constructed for the first four generation-type categories; data at solar thermal plants were insufficient for heat budgets. These heat budgets yielded estimates of the amount of heat transferred to the condenser. The ratio of evaporation to the heat discharged through the condenser was estimated using existing heat balance models that are sensitive to environmental data; this feature allows estimation of consumption under different climatic conditions. These two estimates were multiplied to yield an estimate of consumption at each power plant.

\section{Introduction}

Thermoelectric water consumption ${ }^{1}$ is the water evaporated or incorporated into by-products as a result of the production of electricity from heat. Evaporation from the cooling system accounts for most of the water consumption at most

\footnotetext{
${ }^{1}$ Words and phrases introduced in bold are listed in the Glossary.
}

thermoelectric plants (U.S. Department of Energy, National Energy Technology Laboratory, 2010). In contrast to thermoelectric water withdrawals, which are the largest single water withdrawal category (Kenny and others, 2009), thermoelectric consumption has been estimated to be about 2 percent of total U.S. water consumption, though locally it can be greater (Solley and others, 1998). Thermoelectric water consumption is a critical water use in that thermoelectric plants cannot operate without consuming water, and shutting down power plants imposes costs on society (Eaton, 2012). At the same time, water consumed in thermoelectric power generation is unavailable for other uses.

Thermoelectric water consumption is projected to increase with increasing energy demand (U.S. Department of Energy, National Energy Technology Laboratory, 2010). Moreover, because it is dominated by evaporation, thermoelectric water consumption is inherently sensitive to ambient temperatures and likely to respond to heat waves and changing climate. However, existing reported values and estimates of thermoelectric water consumption do not provide the accuracy, transparency, and temperature sensitivity needed to monitor water consumption and predict its growth.

Available thermoelectric water use data are inconsistent and incomplete (Diehl, 2011). The available thermoelectric water use data are self-reported by plant operators, and techniques for measuring or estimating the main water flows are not standardized. The U.S. Energy Information Administration (EIA) maintains the most complete and consistent database of thermoelectric water use, but plants with water-using generation capacities of less than 100 megawatts (MW) are not required to report water consumption to the EIA, and in 2010 nearly half of the plants that were required to report consumption either did not report consumption or reported zero consumption (U.S. Department of Energy, Energy Information Administration, 2011a, 2011b).

Because reported values are incomplete and inconsistent, water consumption is frequently estimated by multiplying total net generation for various combinations of generating technology and cooling-system types by coefficients that are supposed to give average consumption in gallons per kilowatt hour for each plant category. However, published coefficients disagree widely with one another (Macknick and others, 2011). All are based on data subject to the limitations 
discussed above; some are derived using poorly documented methods, and some are thermodynamically unrealistic (Diehl, 2011). Moreover, published coefficients relating typical evaporation to electric generation do not vary with environmental conditions; the coefficients cannot be used to estimate regional or seasonal variability or responses of water consumption to unusual weather or climate change.

In 2010, the U.S. Geological Survey (USGS) inititated a study to estimate water consumption by thermoelectric power plants as part of the USGS National Water Use Information Program and the agency's broader mission to provide scientific information to manage U.S. water resources. This study was motivated in part by recommendations of the Government Accountability Office (U.S. Government Accountability Office, 2009) that the USGS resume reporting thermoelectric water consumption in the U.S., last reported for 1995 (Solley and others, 1998). This study was undertaken with the support of the National Water Census and National Streamflow Information Program. The methods developed to estimate water consumption for this study based on linked heat and water budgets are part of the ongoing nationwide assessment of water supply and demand and complement existing recommended methods for quantifying water use (Hutson, 2007; Templin and others, 1999).

The methods in this report describe how electric-power generation technology and cooling system technology interact to determine the amount of water consumed. They can be used to estimate water consumption for individual plants, and to define ranges within which reported values of consumption are thermodynamically realistic. They reflect the dependence of water consumption on air temperatures, wind speed, water temperatures, flow, and plant characteristics and operations. They include forced evaporation - the additional evaporation downstream from power plants caused by heat added to water bodies by power plants, over and above the evaporation that would occur in the absence of artificially added heat.

\section{Purpose and Scope}

This report describes (1) methods for estimating consumptive freshwater use at thermoelectric plants, and (2) a two-tiered classification system for thermoelectric plants, based on generation technology and cooling technology.

This report develops heat and water budget models to estimate water consumption at U.S. power plants with waterusing cooling systems and generating capacities greater than 1 megawatt (MW). Model development included three major tasks:

- Compiling data on selected plant characteristics, plant operations, and environmental conditions,

- Combining these data into budgets of the major flows of heat and water at the level of the plant or subunits of the plant, and
- Modeling water consumption based on these heat and water budgets.

Geographic areas include the 50 States and the District of Columbia. Power plants in Puerto Rico and the U.S. Virgin Islands are not surveyed by the Energy Information Administration.

\section{A Heat Budget Approach to Thermoelectric Water Consumption}

Heat budgets were used to model thermoelectric water consumption at the plant scale for 1,284 water-using power generation facilities in the U.S. A linked heat and water budget was constructed for all thermoelectric plants that provided enough information on plant characteristics and operations. In addition to the estimated most-likely consumption, high and low limit values were estimated based on estimated errors in the budget model. These limit values define a range of consumption values that are likely to be consistent with thermodynamic constraints. Reported values of consumption outside this range are unlikely to be correct based on apparent violation of the thermodynamic constraints. Where the reported amount of water consumption is consistent with the estimated consumption, the reported number can be considered validated. At plants without reported water use, the budget results provide a useful, if imprecise, estimate of thermoelectric water consumption.

For a given period of time at a given plant, the energy made available to drive water consumption through evaporation cannot exceed the difference between the energy contained in consumed fuel and that contained in the plant's electrical output. This difference represents total energy (or heat) dissipated to the environment - a large portion of which drives evaporation of water unless dry cooling is used. Heat-budget computations based on the conservation of mass and energy and records of fuel use and power generation can provide an important, independent means to constrain estimates of thermoelectric water consumption (Rutberg and others, 2011) within bounds determined by the availability of waste heat to evaporate water and the design of the cooling system.

Evaporation at thermoelectric plants depends on both the method by which electricity is generated (generation type) and the method by which waste heat is removed from the system (cooling-system type). Because generation type and cooling-system type represent two distinct and independent stages in the overall process of thermoelectric water consumption, it is useful to consider them separately. This leads to a two-tiered classification of thermoelectric plants that provides an analytical framework for estimation based on two key processes: the production of waste heat and the conversion of waste heat to evaporation.

The share of fuel energy converted to waste heat depends for the most part on the generation type and design but is little 
affected by cooling-system type, plant elevation, and environmental conditions. Generation type represents a complex of various systems that convert fuel to heat or otherwise capture heat, and convert heat to electricity and waste heat. In typical steam plants, these systems include a boiler, steam turbine, condenser, and auxiliary equipment. Combined-cycle plants also include combustion turbines. In either case, distilled water is converted to high-pressure steam in a boiler and drives a steam turbine before being re-condensed and returned to the boiler in a closed loop. The heat removed from the steam and transferred to cooling water by a condenser is the majority of waste heat and is defined as the condenser duty of the plant. Five generation types classified by electrical generation technology and energy source (table 1) produce distinct estimates of condenser duty. Plants in each of these types report different kinds of information at different levels of aggregation to the EIA. These differences, combined with known technological characteristics of each type, make it necessary to estimate condenser duty with different techniques for each generation type.

The share of condenser duty that goes to produce evaporation depends on cooling-system type as well as a number of environmental conditions, such as plant elevation, air temperature, humidity, wind speed, and ambient water temperature. Generally, cooling systems transfer the bulk of condenser duty to the atmosphere through evaporation and the rest is lost through conduction and radiation (Huston, 1975). Six cooling-system types are common (table 2), of which only three consume freshwater. Of these, most thermoelectric plants built recently have one or more wet cooling towers. Inside these towers, hot water is exposed to flowing air over a large surface area. Heat in the cooling water is transferred to air mostly as latent heat through vaporization and to a lesser extent as sensible heat through conduction. These two processes warm the air as it passes through the tower and leave it approximately saturated with moisture. The main alternative to the use of wet cooling towers is surface-water cooling, whereby heat is transferred to the atmosphere from the free surface of an extensive body of open water. Though a greater portion of waste heat may leave as convection and long-wave radiation from surface-water cooling systems, a substantial portion remains to be accounted for in evaporation.

For any given cooling system, the fraction of condenser duty that goes to produce evaporation is expressed as the evaporation ratio of that system. Because all systems lose at least some waste heat through other processes, evaporation ratios have values less than one. Evaporation ratios for towers are primarily sensitive to ambient vapor pressure and air temperature (wet bulb and dry bulb); ratios for surface-water cooling systems are primarily sensitive to ambient water temperature and wind speed.

Based on the characterizations and analyses described above, a heat-budget approach can be applied in four steps: (1) model the condenser duty for each generating unit independent of the type of cooling system; (2) model the evaporation ratio for the various types of cooling systems used by the generating unit; (3) compute the heat transferred to the atmosphere as the product of condenser duty and evaporation ratio; and (4) compute the weight of evaporated water and its liquid volume from the water temperature and the specific heat of evaporation. Each of these steps requires specific information, which may be available in varying degrees of quality and completeness. The available heat in the fuel entering the plant and the energy in the electricity that leaves the plant are well measured at most plants, and the difference between them is the heat rejected by the plant. Condenser duty is the largest component of heat rejection, and the other components, losses from auxiliary equipment and heat in the exhaust gas, are estimated based on generation type. Environmental variables and the type of cooling system control the evaporation ratio. The cooling system models use monthly averages of dry bulb air temperature, wet bulb air temperature, ambient surface-water temperature, and wind speed, as well as plant elevation data. Verified plant locations were used to validate cooling-system types and to link environmental variables and elevations to plants.

Table 1. Generation-type classification categories used to estimate condenser duty.

[The prime mover is the turbine that converts the energy in heated gases to mechanical energy.]

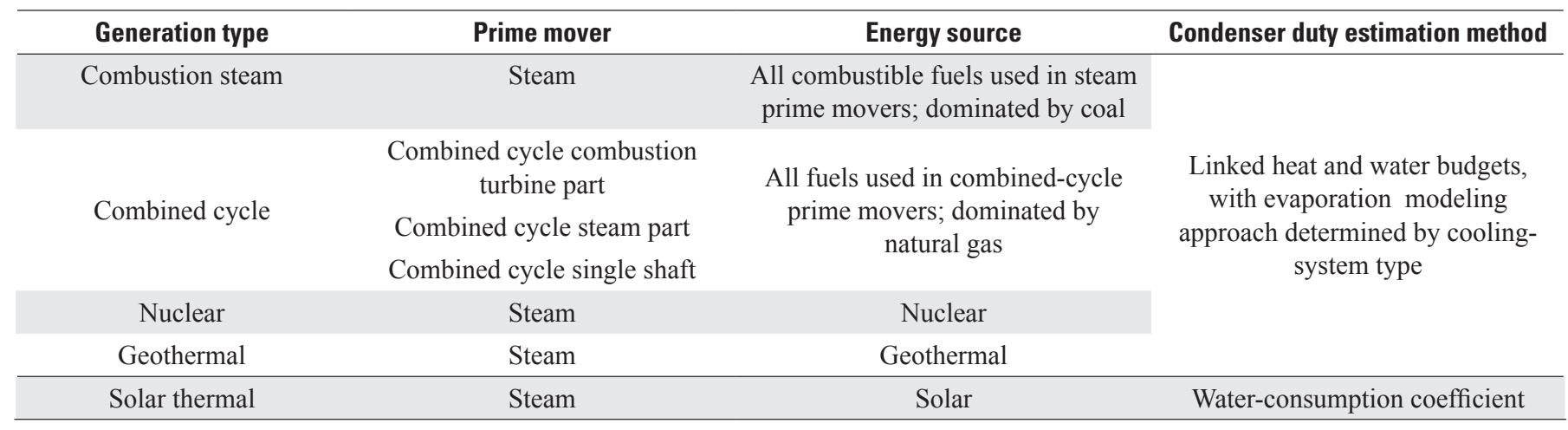


Table 2. Cooling-system type classification categories used to estimate evaporation.

\begin{tabular}{cc}
\hline Cooling-system type & Evaporation modeling approach \\
\hline $\begin{array}{c}\text { Wet freshwater recirculating } \\
\text { cooling tower }\end{array}$ & Wet tower evaporation model \\
Recirculating pond or canal & Water surface evaporation model \\
Once-through freshwater & \\
Wet saline recirculating cooling \\
tower
\end{tabular}

\section{Data Compilation and Quality Assurance}

Classifying power plant technologies and developing methods for estimating water consumption required specific thermoelectric plant-characteristic, operational, locational, and environmental data. Data were compiled from EIA, the U.S. Environmental Protection Agency (USEPA), the National Energy Technology Laboratory (NETL), the National Oceanic and Atmospheric Administration (NOAA), and USGS national databases. The data were incorporated into the classifications and methods either as initially reported, or as variables to calculate numerical values needed to estimate condenser duty and evaporation.

\section{Plant Master List}

The final list of plants for this study (herein referred to as the plant Master List) has 1,284 thermoelectric, water-using power plants. These plants were identified using plant-characteristic data from the 2010 EIA-860 Annual Electric Generator Report database (Appendix 1). For this study, power plants were limited to electricity-generating facilities that have been assigned unique plant codes by the EIA. At the broadest level, power plants with existing generators (as opposed to plants with retired or proposed generators) had 5,824 unique records in the EIA-860 database. Eliminating plants with existing generators that were not active in 2010 narrowed the group to 5,344 plants. Of these, 1,713 were identified as having water-using thermoelectric generators based on prime mover, which is the turbine that converts the energy in heated gases to mechanical energy. Based on the North American Industry Classification System (NAICS) codes (U.S. Census Bureau, 2007), water-using thermoelectric generators can be further subdivided into industrial and commercial facilities and electric utilities. After eliminating industrial and commercial facilities, which are grouped by the USGS in separate water use categories, 1,329 electric utility power plants remained.
Some of these plants use dry cooling systems, which do not evaporate water, and therefore were removed leaving a revised total of 1,284 plants that fit all study criteria. Within the final Master List, 217 plants were described as combined heat and power plants and required a modified water consumption estimation model.

\section{Generation Data}

Generation data, compiled from the 2010 EIA-860 Annual Electric Generator Report and the EIA-923 Power Plant Operations Report databases, include both the plantcharacteristic data used to classify generation types and operational data used to model condenser duty (Appendix 2, table 1). Plant-characteristic data, including prime mover, energy source, boiler efficiency, interconnections (associations) between boilers and generators, and flue-gas desulfurization (FGD) types, are generally the same from year to year and are not dependent on annual operations unless entire boilers, generators, or cooling systems are brought on or off line. Operational data including the amount of fuel consumed (electric and total fuel heat produced) and the net amount of electricity generated by each plant will typically vary by month and year.

The portion of fuel heat converted to condenser duty depends on the design of each plant. Five generation types have been identified based on prime mover and energy source: combustion steam, combined-cycle, nuclear, geothermal, and solar thermal (table 1). Steam turbines, which are associated with water-using cooling systems, are used with all of these generation types but are fueled by different energy sources. Whereas coal provides most of the heat to combustion steam turbines, a wide variety of other fuels also is used. Steam turbines at nuclear, geothermal, and solar thermal plants are powered by their respective noncombustive energy sources. Combined-cycle plants use a combination of combustion turbines and steam turbines to generate electricity in which exhaust from a combustion turbine (commonly powered by natural gas) boils water to power a steam turbine. Each generation type has a condenser duty range that is contingent upon the amount of fuel heat used to generate electricity. Detailed lists of prime movers, energy sources, and associated EIA codes are given in Appendix 2, tables 2 and 3.

Data on fuel consumption, electric generation, and plant characteristics are fundamental to the heat-budget approach, but the availablility and quality of these data vary widely among different generation types. In general, reported net electric generation data for all generation types were of good quality, principally because the amount of electricity transmitted to the electrical distribution grid is well measured. Fuelconsumption data, on the other hand, were of consistently good quality only for combustion-steam and combined-cycle plants. Because total heat values from fuel consumption in nuclear, geothermal, and solar thermal plants are difficult to define and measure, reported values for these plants were 
nominal at best (producing unrealistic thermal efficiencies) and had to be estimated. Boiler efficiencies reported for most combustion-steam plants were thermodynamically realistic, but at some plants boiler efficiency had to be estimated based on the types of fuels burned. The boiler efficiencies reported for combined-cycle plants were thermodynamically unrealistic and were not used in heat budgets. FGD-type data reported for combustion-steam plants were assumed to be accurate. Electric-fuel consumption data reported for combined heat and power plants were generally of adequate quality for computing the amount of heat exported to associated heat-using processes.

\section{Cooling System Data}

Cooling system data are the plant characteristics used to classify cooling-system types, interconnections between cooling systems and boilers, and the locational and environmental data used to estimate water consumption. The amount of waste heat transferred from the condenser to the atmosphere through evaporation depends on the cooling-system technology and the environmental variables associated with the plant locations.

\section{Power Plant Locations and Elevations}

Locations for each thermoelectric plant link aerial imagery, plant elevation, environmental data, and catchment areas necessary to estimate power plant-specific water consumption. To ensure correct links among these datasets, multiple, often conflicting, power plant locations from EIA, NETL, and USEPA databases were evaluated using standard geographic information system (GIS) procedures (U.S. Department of Energy, Energy Information Administration, 2001, 2009, 2011a; U.S. Department of Energy, National Energy Technology Laboratory, 2007b; U.S. Environmental Protection Agency, 2007a, [n.d.]). Power plant locations were verified and then matched to USEPA's National Hydrography Dataset Plus (NHDPlus) to determine elevation and assign river catchments (U.S. Environmental Agency, 2007b). Those locations and associated metadata were stored in an internal USGS GIS database.

Locations of record for power plants were verified by inspecting digitally mapped site locations using GIS and other computer-aided techniques. A point-data layer was created from seven sets of coordinates composed of 19,496 power plant locations. The sets of coordinates were from four U.S. Department of Energy (DOE) databases: the 2000, 2008, and 2010 Form EIA-860 databases (U.S. Department of Energy, Energy Information Administration 2001, 2009, 2011a), and the NETL Coal Power Plant Database [CPPDB] (U.S. Department of Energy, National Energy Technology Laboratory, 2007b), and two USEPA databases: the Enforcement and Compliance History Online [ECHO], which is composed of two datasets (U.S. Environmental Protection Agency, [n.d.]), and the Emissions \& Generation Resource
Integrated Database [eGRID] (U.S. Environmental Protection Agency, 2007a). In many instances, these different sources produced more than one location for each power plant. To reconcile those locations, a second data layer containing the mean center location for sites with multiple locations was created. Mean center locations for each plant were then adjusted in a final point layer based on GIS-facilitated analysis of aerial imagery and other available information. A reference layer of power plants was extracted from the 2011 Homeland Security Infrastructure Program (HSIP) Gold database (Appendix 3) and used for visual site verification. This information, however, could not be directly linked to EIA, NETL, or USEPA location datasets by plant name or EIA plant code. Linkages were made using other location information provided in several base layers obtained from USGS topographic maps at various scales, road maps, aerial photography, and satellite imagery as well as GIS-facilitated internet searches of publically available mapping services.

The location verification procedure involved a series of power plant-specific queries within the GIS display points by plant code number. This reduced the number of points by eliminating all other power plants from the screen so that only the multiple locations of the queried power plant were displayed. The reduced area provided a general location of a plant from which a search could be conducted. The search began by finding the HSIP power plant location, and determining its proximity to the mean center location. If a plant could not be located and verified by aerial imagery, the plant's address was used to conduct a visual search in the area defined by the extent of all points with the same EIA power plant code, and to execute an internet search for any other information about the plant that could be used to find its actual location (fig. 1). Power plant locations were then overlain with NHDPlus version 1.1 data to determine elevation and river catchment area (U.S. Environmental Protection Agency, 2007b).

\section{Cooling-System Type Validation}

Cooling-system types were classified into two basic categories: wet cooling towers and surface-water cooling systems (table 2). Power plants that have water-using generation capacities of $100 \mathrm{MW}$ or greater are required to report cooling-system types to the EIA; 802 Master List plants fit this criterion. However, this information is sometimes inaccurate or is incomplete, as is the case with the 482 Master List plants not required to report. Therefore, verified power plant locations and internet searches were used to validate the coolingsystem types for the Master List power plants.

Analysts were trained to identify the various types of cooling systems using aerial imagery in Google Earth and Bing Maps. Wet cooling towers include natural-draft towers and two types of mechanical-draft towers, induced-draft and forced-draft towers, which are all readily identifiable from aerial imagery. Natural-draft towers are identifiable as large, hyperboloid structures with pronounced top openings (fig. 2); air flow through natural-draft towers is driven by 

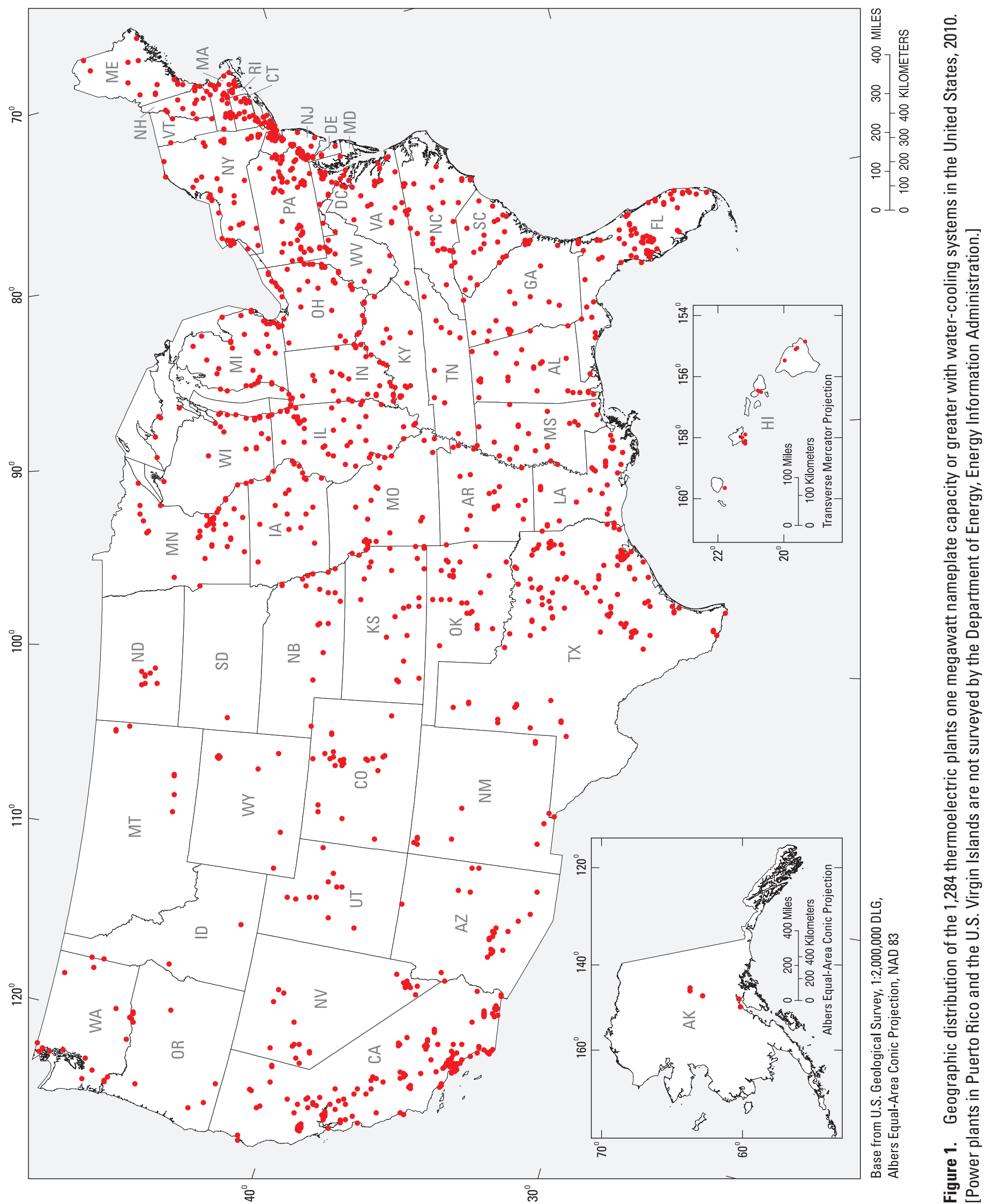


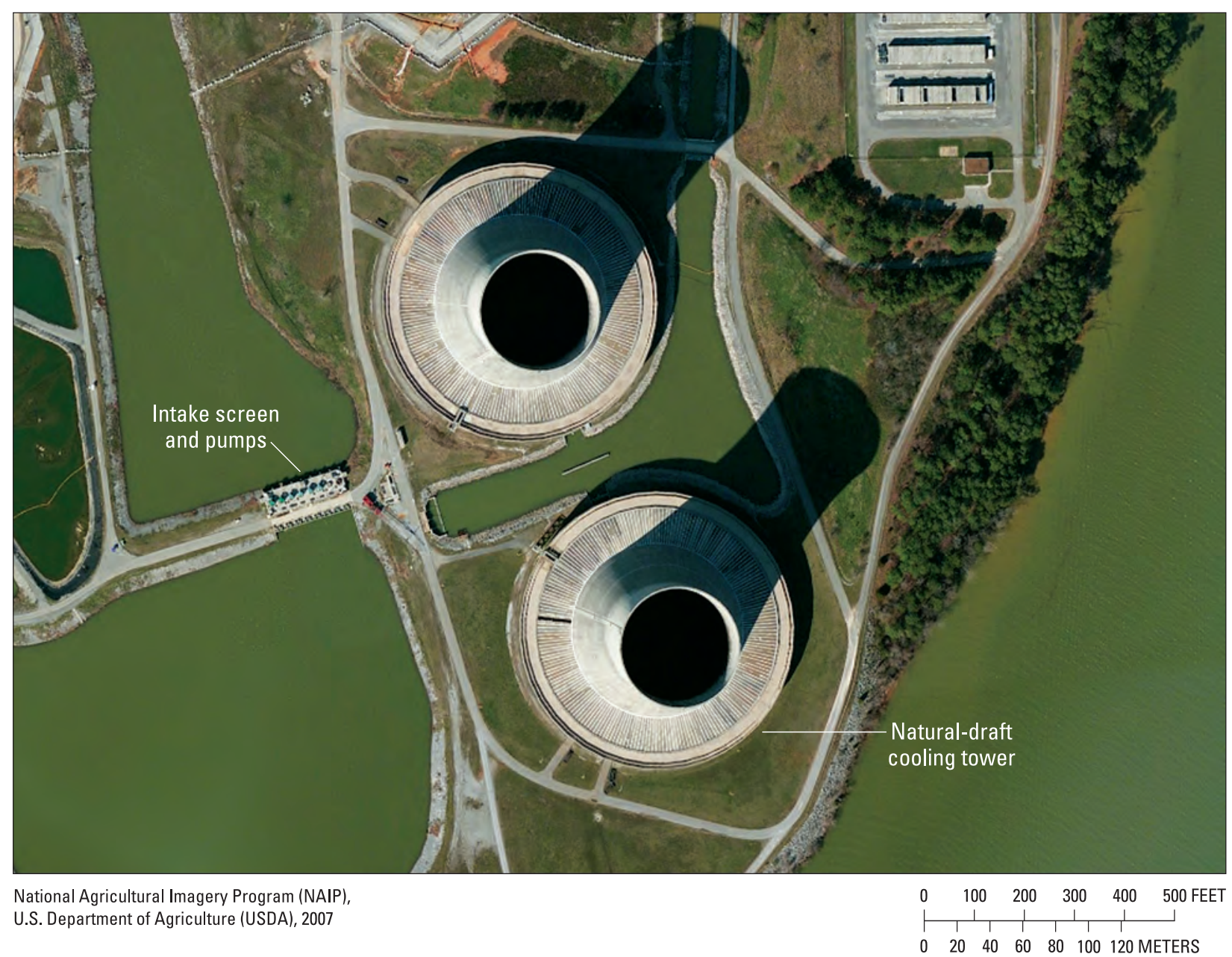

Figure 2. Natural-draft cooling towers and one of two intake screens and associated pumps for the Tennessee Valley Authority, Sequoyah Nuclear Power Plant, Tennessee. Natural-draft tower airflow is drawn through the packing or fill (distributed at the base) by means of the small density difference between the warm moist air inside the tower and the cooler ambient air outside the tower (Stultz and Kitto, 1992). Because of the small temperature and density difference, these cooling towers tend to be tall. These towers are relatively open cylindrical structures. Modern units are sometimes referred to as hyperbolic towers because of their shape. The heat rejected from the steam to the cooling water is circulated through the cooling tower where the heat is rejected to the atmosphere as latent and sensible heat.

convection. Induced-draft towers have large fans on top of the tower structure that pull air up through the tower (fig. 3). Forced-draft towers are generally rectangular and have a radiator-like appearance across the top; the fans are located in the bottom of these towers and push air up through the tower structure (fig. 4). Many dry cooling systems, known as aircooled condensers, also have a radiator-like appearance, but most have large pipes running the length of the structure that aid in identification (fig. 5). Surface-water cooling systems include once-through cooling systems and recirculating cooling pond or canal systems. Once-through cooling systems take water from a surface-water body, transfer heat into it, and discharge the water to a surface-water body; little or none of this discharged water is recirculated through the condenser. Recirculating ponds and canals are similar but have much smaller surface-water inflows and outflows, so that the water in them is recirculated many times through the condenser. Once-through cooling systems were identified by the coolingwater intake structures that feature intake pumps and screens located in and beside water bodies (fig. 6) and discharge outlets (fig. 3) characterized by concentrated, fast-flowing water with visible foam. Once-through cooling systems can be located on coastal waters, rivers, lakes, or ponds. Because the type of water body determined the surface-water evaporation model that was used, the areas of lakes and ponds were measured to assist in establishing a surface-water cooling subcategory (coastal waters and rivers are evident). Ponds were distinguished from lakes at this stage as being smaller than lakes and lacking irregular natural shorelines (fig. 7). Both natural lakes and reservoirs were assigned to the lakes 


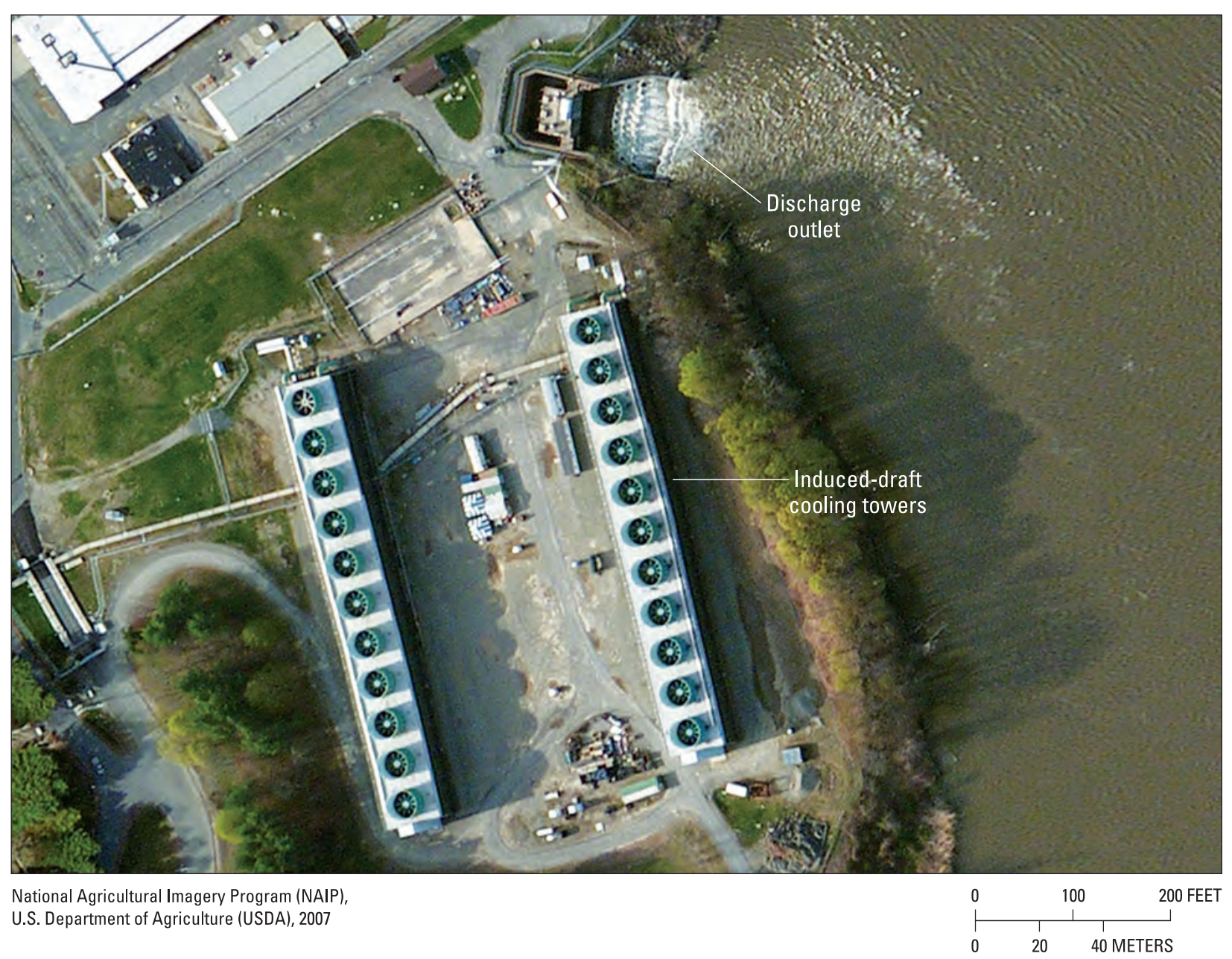

Figure 3. Mechanical induced-draft cooling towers (wet cooling towers) and the discharge outlet for Entergy Vermont, Vermont Yankee Nuclear Power Plant, Vermont. With the mechanical induced-draft cooling towers, the fan is located downstream of the air and water interface and the air is drawn through the cooling tower (Stultz and Kitto, 1992). Airflow distribution is typically more uniform and less prone to ground interference or recirculation. The heat rejected from the steam to the cooling water is then circulated through the cooling tower where the heat is rejected to the atmosphere as latent and sensible heat.

subcategory (fig. 8). Later, several lakes were redefined as ponds on the basis of high heat loading. A list of the coolingsystem types and their associated EIA codes is presented in Appendix 2, table 4.

Determining cooling-system types for some plants proved more difficult and professional judgement was needed for identification. Some once-through plants, for example, have intakes or outlets that are submerged and cannot be located using aerial imagery. In such cases, if no other cooling system could be identified (for example, towers) and the plant was located next to a river, lake, or coastal water body, it was determined to have a once-through system. Some dry cooling systems known as heat exchangers have a similar appearance to wet cooling towers and are difficult to identify. Additionally, locating and linking cooling systems to plants within industrial complexes or within close proximity of another plant relied on subjective decisions.
After validating cooling-system types, most of the reported forced-draft cooling towers were reclassified as induced-draft cooling towers. For the non-reporting plants, the majority of the cooling-system types were identified as induced-draft cooling towers. Overall, of the 1,284 power plants in the Master List, most were classified as wet tower systems (fig. 9). Some, with multiple cooling-system types, were classified as complicated and consumption by each cooling-system type was modeled separately.

\section{Environmental Data}

The evaporation models require several environmental input variables that are specific to each power plant. The environmental inputs needed for the surface-water evaporation model include: site elevation, monthly mean wet bulb and dry 


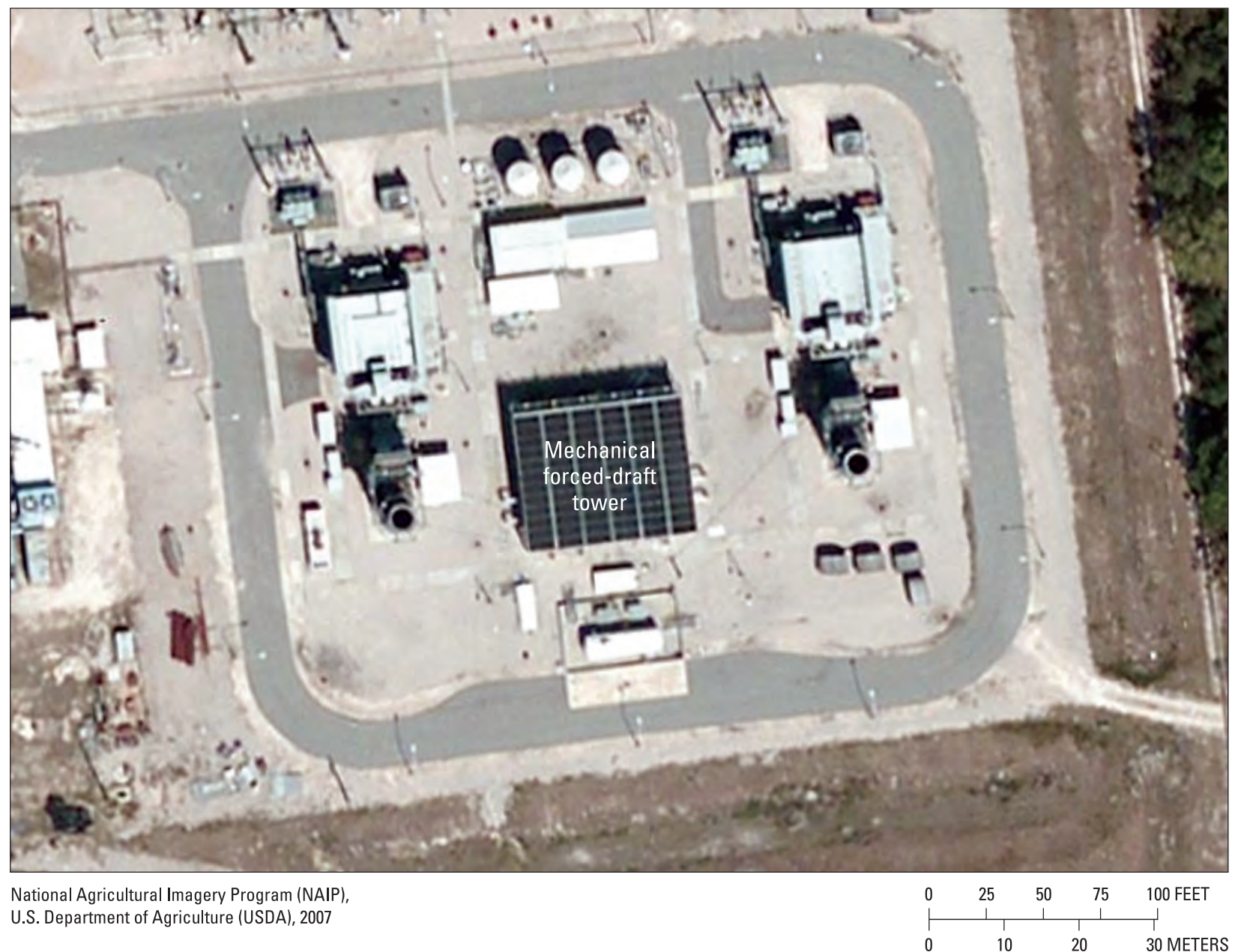

Figure 4. A mechanical forced-draft tower for the City of Tallahassee, Arvah B. Hopkins Power Generating Station, Florida. In mechanical forced-draft cooling towers, fans are typically located upstream of the air/water interface (Stultz and Kitto, 1992). In this case the air is drawn through the cooling tower. The heat rejected from the steam to the cooling water is then circulated through the cooling tower where the heat is rejected to the atmosphere as latent and sensible heat.

bulb air temperatures, monthly mean water temperature, and monthly mean wind speed. Environmental inputs needed for the tower evaporation model include: elevation, monthly mean wet bulb and dry bulb temperatures. Acquisition of elevation data has been described previously; the following discussion focuses on the data sources and determination methods of climate inputs (wet bulb and dry bulb temperatures, and wind speed) and water temperature inputs.

\section{Data Sources}

Land-surface observations from Quality Controlled Local Climatological Data (QCLCD or LCD) collected by the NOAA, National Climatic Data Center (Appendix 3) serve as the foundation for dry bulb, wet bulb, and wind speed determinations. LCD consists of hourly, daily, and monthly summaries of meteorological observations collected at major airports nationwide. In 2010, the LCD network consisted of 1,152 weather stations reporting at least 1 month of meteorological observations.

USGS water temperature measurements, EIA plantreported values, and satellite imagery were the basis for watertemperature determinations, depending on plant location. For plants located on one of the Great Lakes, satellite imagery provided water temperature information. The NOAA Great Lakes Environmental Research Laboratory (GLERL) produces the Great Lakes Surface Environmental Analysis (GLSEA2), which is a daily digital map of lake-surface temperatures and ice cover derived from imagery collected by the NOAA polar-orbiting satellite (Appendix 3). For all other plants, temperature measurements of lakes and rivers from USGS water temperature stations and plant-reported intake temperatures provided by the EIA were used for water-temperature determinations. In 2010, approximately 700 USGS streamgaging 


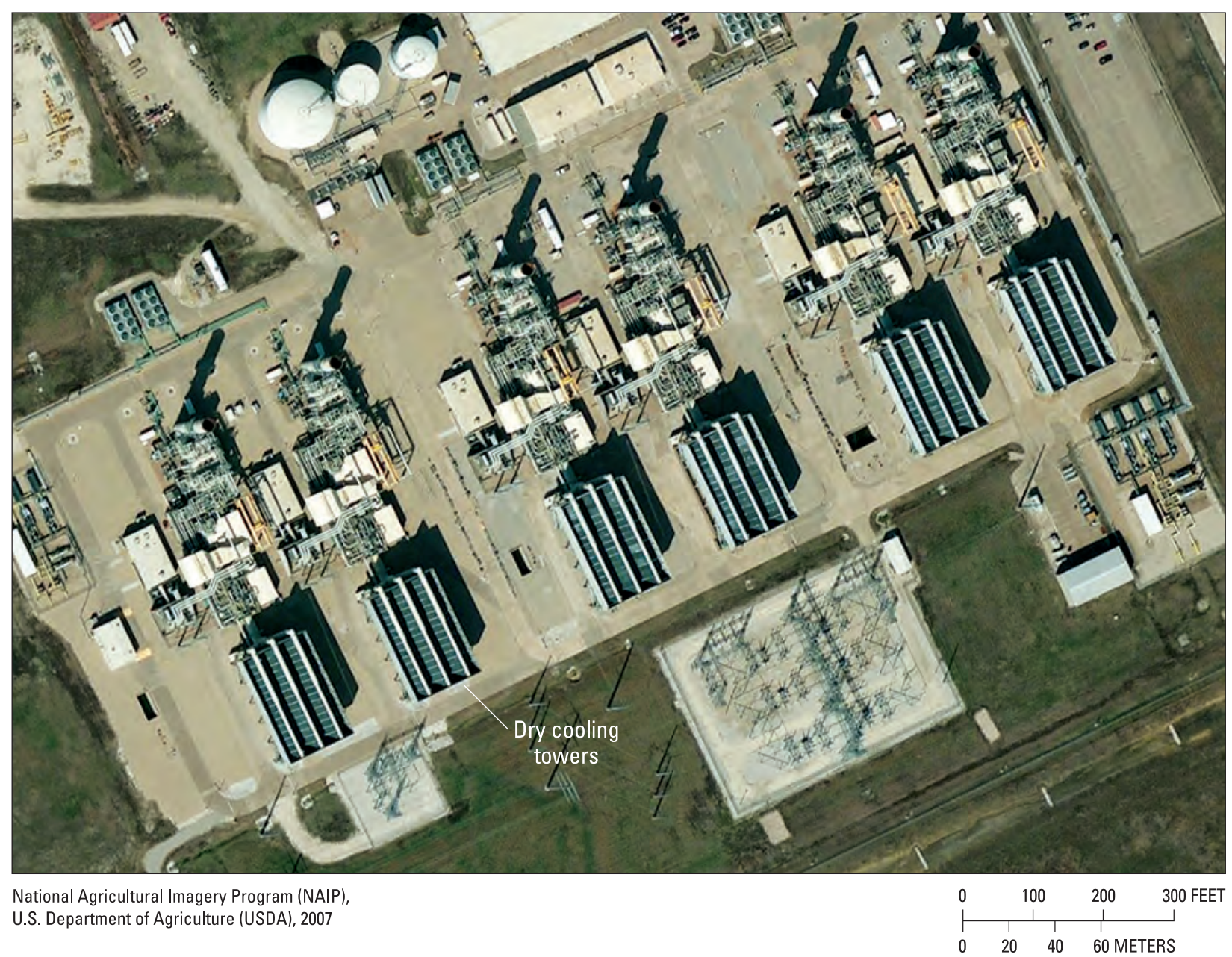

Figure 5. Dry cooling towers for the ONCOR, Midlothian Power Plant, Texas. An air-cooled system may be mechanical or natural draft (Stultz and Kitto, 1992). All the heat rejected from the steam is absorbed in the form of sensible heat gain in the ambient air.

stations recorded daily mean water temperature in the U.S. Monthly mean water temperatures were calculated from this record for months in which fewer than seven daily values were missing. The EIA also collects plant-reported average monthly intake water temperatures (using Form EIA-923) for facilities generating greater than $100 \mathrm{MW}$, which accounted for 381 power plants nationwide in 2010 .

\section{Data Quality}

The quality of the LCD data (dry bulb temperature, wet bulb temperature, and wind speed) is controlled by NOAA, and no additional filtering based on data quality was required. Only stations with complete monthly observations for 2010 were used, and only stations with both dry bulb and wet bulb temperature observations were retained. Of the 1,152 weather stations reporting meteorological observations, 554 stations reported 12 months of monthly mean dry bulb and wet bulb temperatures, and 727 stations reported 12 months of monthly mean wind speed. Stations missing 1 or more months of observations were compiled in separate validations for dry bulb and wet bulb temperature or wind speed and used in an analysis of uncertainty. The geographic distribution of dry bulb and wet bulb stations and wind speed stations used for input determination was fairly uniform across the U.S. (figs. 10 and 11).

No additional quality control was performed on the Great Lakes water temperature map (GLSEA2), however several filtering processes were used to check the quality of USGS and EIA measurements of water temperature. There were 622 USGS water temperature stations after filtering. USGS monthly mean water temperatures were filtered through an iterative process. First, monthly temperatures were screened for extreme values and irregular seasonal patterns such as deviations from a generally sinusoidal curve. Sites that were flagged during this process were visually evaluated and removed from the dataset if they were located in a geothermal 


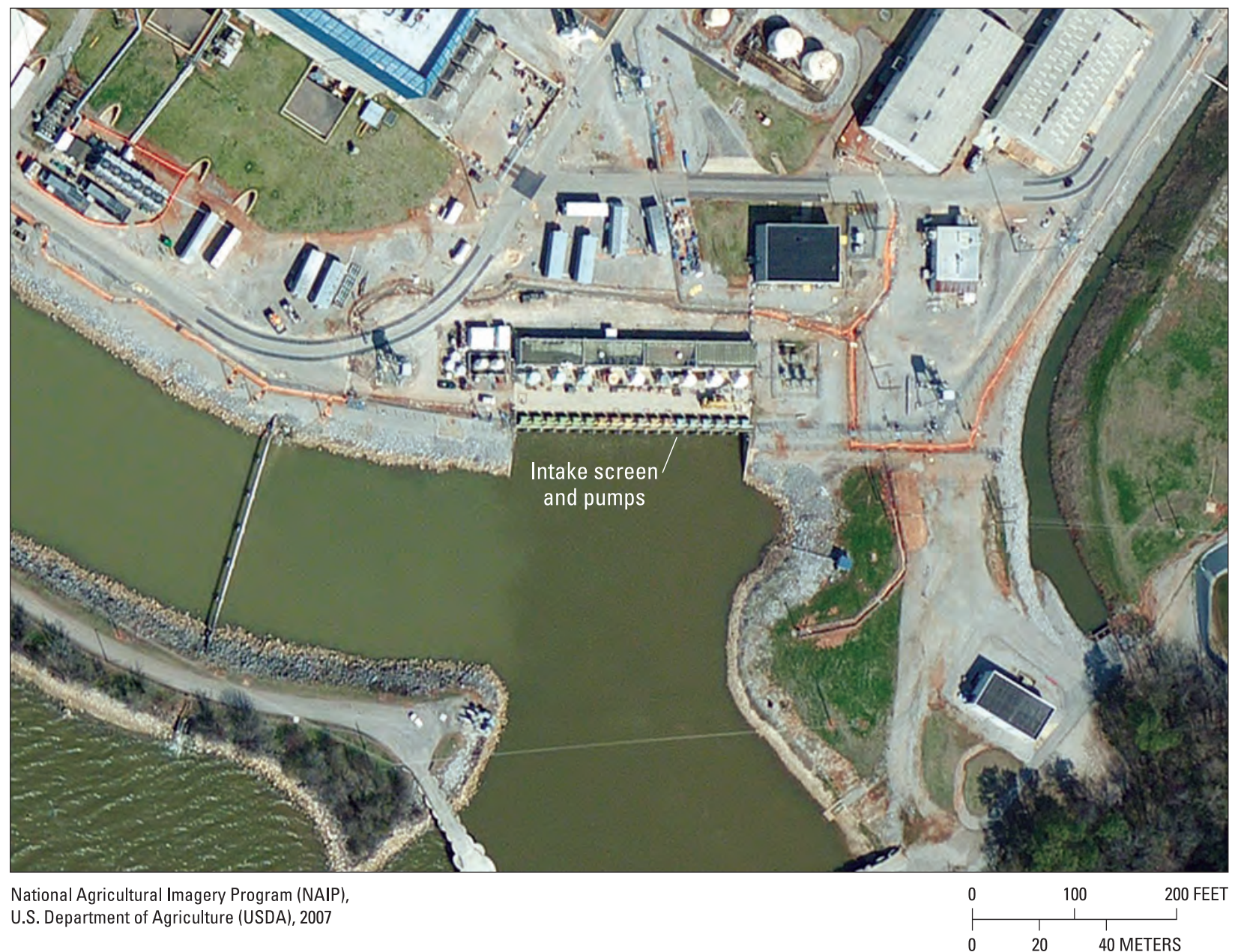

Figure 6. Intake screen and pumps used for once-through cooling at the Tennessee Valley Authority, Browns Ferry Nuclear Plant, Alabama. The discharge outlet is not shown. In once-through cooling, water is withdrawn from a source, circulated through the condenser, and then returned to a body of water at a higher temperature (Kenny and others, 2009). The heat is rejected as latent and sensible heat (Stultz and Kitto, 1992).

area or below a dam. Leave-one-out cross-validation (Breiman and Spector, 1992) was used to identify possible errors in water temperature at remaining sites and a site was flagged if its error was greater than two standard deviations from the mean error of the cross-validated estimates. Flagged sites were then visually evaluated to determine their appropriateness for the dataset.

Plant-reported, monthly average intake water temperatures collected by EIA were initially filtered based on the method of measurement. Only plants that indicated water temperature was measured at intervals (for example, daily) with a thermometer or measured continuously with a thermometer were retained. Furthermore, only plants that reported once-through freshwater cooling systems were retained. Remaining sites were then screened for extreme values and irregular seasonal patterns and subjected to the same crossvalidation process described above. There were 133 plants with monthly mean intake water temperature after filtering.
Monthly temperature data from the USGS were combined with plant-reported EIA data and the water temperature dataset used for input determination contained 755 sites with at least 1 month of water temperature in 2010. The geographic distribution of water temperature sites varies by month and is not uniform across the U.S., particularly in the Southwest, where water temperature information is sparse (fig. 12).

\section{Methods of Determination for Environmental Input Variables}

For each plant, climate inputs were determined by interpolation among nearby weather stations with dry bulb and wet bulb observations (fig. 10) or wind speeds (fig. 11). Using a 100 -mile search radius, the distances from each plant to the nearest three weather stations were determined and used to compute a weighted mean of climate variables based on the inverse of distance from the respective plant. 


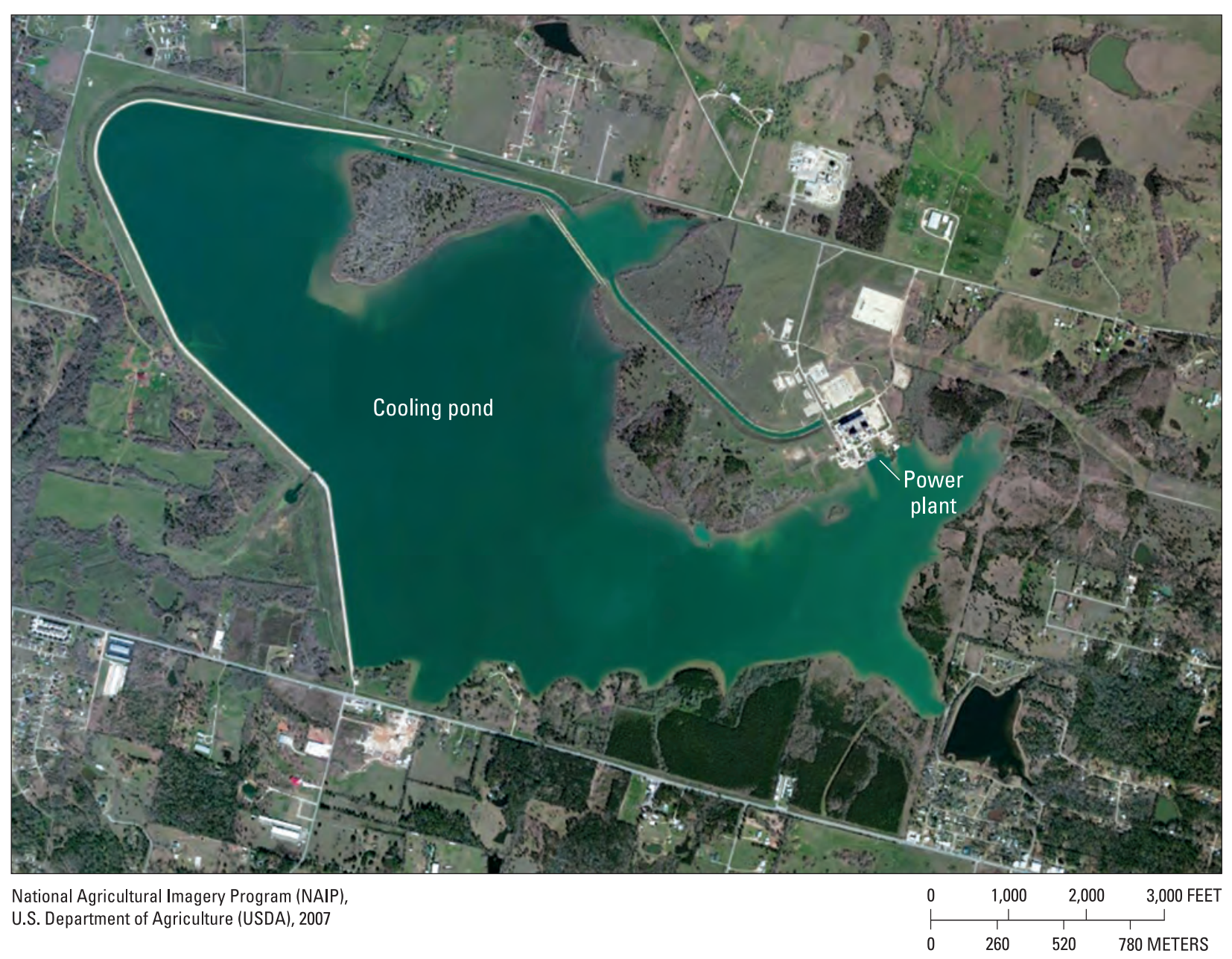

Figure 7. The approximately 2.5-mile-long cooling pond for the Entergy Texas, Lewis Creek Generating Plant, Texas. Water is withdrawn and returned to Lewis Creek Reservoir.

Empirical Bayesian kriging (Krivoruchko, 2012; Pilz and Spock, 2007) produced an interpolated water-temperature surface for the continental U.S. by month based on both USGS and EIA data. Water-temperature inputs for plants located on rivers, lakes, and reservoirs were determined based on their location. An inverse-distance weighted average was not used for water temperature because the geographic distribution of water temperature sites was not uniform across the U.S. (fig. 12). Empirical Bayesian kriging was used because it accounts for the error introduced by the selection of an underlying model of variation (semivariogram), providing smaller standard errors of prediction than other kriging methods (Esri, 2012). Additionally, a subsetting process allows for accurate predictions of moderately nonstationary data (Esri, 2012). Using tools included in the ArcGIS 10.1 Geostatistical
Analyst Toolbar and Toolbox (Esri, 2012), observed temperature data were divided into local subsets. For each subset, a semivariogram model was estimated. Using this semivariogram, estimates of water temperature were simulated for each of the locations in the subset. The empirical Bayesian kriging tool iterated through this computation a specified number of times to produce a distribution of semivariograms for each subset. Local models were then derived from those distributions to produce a final predictive model (surface map) of average water temperature by month.

Empirical Bayesian kriging did not work well for plants located on the Great Lakes. An initial trial using a kriged surface to determine water temperatures for the Great Lakes resulted in large differences from observed water temperatures. Therefore, remotely sensed water-temperature 


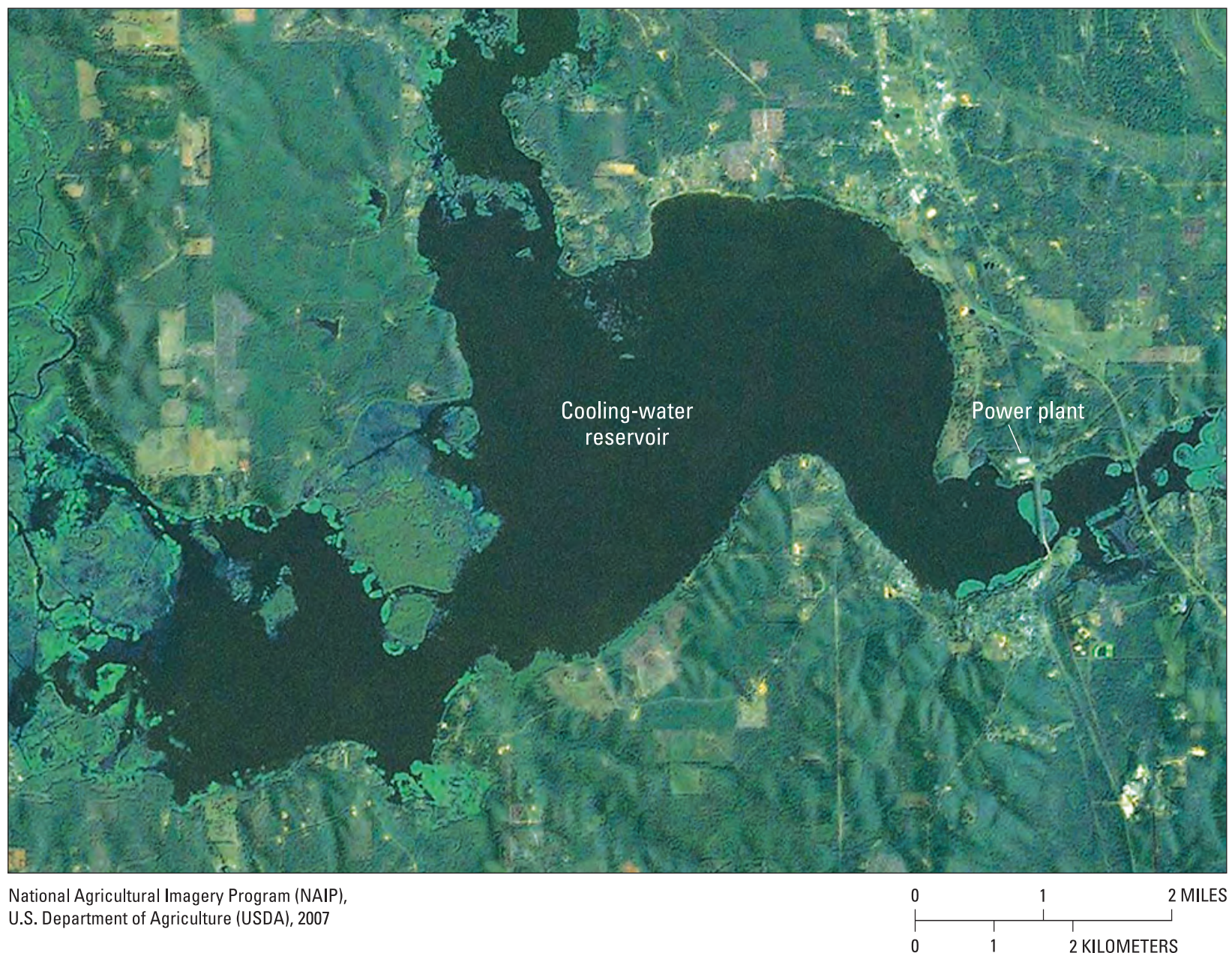

Figure 8. The approximately 8-mile-long cooling-water reservoir for the Southwestern Electric Power, Lieberman Power Plant, Louisiana. Water is withdrawn and returned to Caddo Lake. In once-through cooling, water is withdrawn from a source, circulated through the heat exchangers, and then returned to a body of water at a higher temperature (Kenny and others, 2009). In once-through cooling, the heat is rejected to a body of water as latent and sensible heat (Stultz and Kitto, 1992).

information (GLSEA2) provided by the NOAA GLERL was used to determine water temperatures. Daily average water temperatures at the location of each plant on the Great Lakes were retrieved from satellite imagery and aggregated to a monthly mean.

\section{Uncertainty Analysis}

The uncertainty associated with the three input determination methods described above was assessed by comparison to a validation dataset of sites that were dropped from model development because of missing data. Using the same basic approach applied to power plants, dry bulb temperature, wet bulb temperature, and wind speed were estimated for each validation weather station and compared to observed record to determine estimation error. Based on that analysis, approximately 95 percent (two standard deviations) of dry bulb validation temperatures were within plus or minus 3.2 degrees Celsius $\left({ }^{\circ} \mathrm{C}\right)$ (5.8 degrees Fahrenheit or ${ }^{\circ} \mathrm{F}$ ). Similarly, approximately 95 percent of wet bulb validation temperatures were within plus or minus $2.0^{\circ} \mathrm{C}\left(3.6^{\circ} \mathrm{F}\right)$. Wind speeds were typically within plus or minus 3.7 miles per hour (mph). The dry bulb/wet bulb validation dataset consisted of 598 weather stations that had fewer than 12 months of 2010 observations, which accounted for 4,551 monthly observations across the validation dataset. The wind speed validation set included 424 weather stations missing 1 or more months of data, which accounted for 1,800 monthly observations across the validation dataset.

Uncertainty associated with water-temperature estimates derived from kriged surfaces was assessed using leave-one-out 


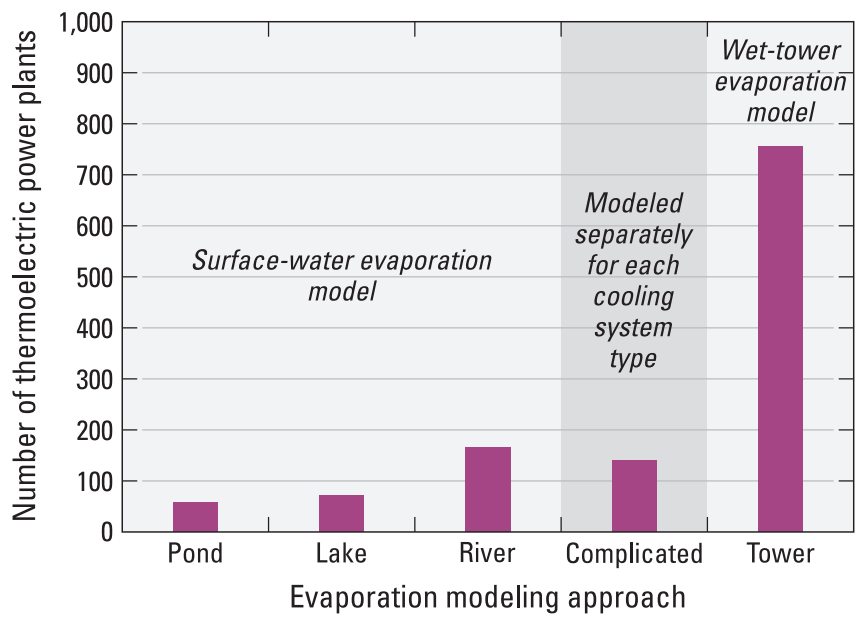

Figure 9. The distribution of cooling-water types for modeling evaporation for 1,284 thermoelectric plants. Complicated refers to multiple cooling types for a single plant. Tower refers to wet recirculating cooling tower.

cross-validation within ArcGIS. Kriged water temperatures were within plus or minus $3.6^{\circ} \mathrm{C}\left(6.5^{\circ} \mathrm{F}\right)$ of those observed. Remotely sensed water temperatures were assessed for uncertainty by comparison to observed temperatures at plants on the Great Lakes. Approximately 95 percent of remotely sensed water temperatures were within plus or minus $6.3^{\circ} \mathrm{C}\left(11.3^{\circ} \mathrm{F}\right)$ of the observed temperatures. The greater uncertainty of remotely sensed data on the Great Lakes may result from the recirculation of heated discharge water in the vicinity of plant intakes. This effect may occur at such a small scale that it is not captured in satellite imagery.

\section{Supplemental Methods}

For a few plants, environmental conditions could not be determined using the methods described above and the uncertainty in these estimates is difficult to evaluate. Based on the quality of nearby records, dry bulb or wet bulb temperatures could not be estimated at six plants, and because the kriged surface did not extend to Alaska and Hawaii, water temperatures could not be estimated for 19 plants. For the six plants at which the previously described methods did not yield estimates of dry bulb and wet bulb temperatures, the nearest weather stations that were missing 1 or more months of observations were used. Values for the the missing months at these stations were estimated by averaging the preceding and following monthly observations. Also, in a few instances, estimated wet bulb temperatures were higher than dry bulb temperatures so the two were set to equal dry bulb temperatures. For plants in Alaska and Hawaii, records from the nearest USGS water temperature stations were used to estimate water temperatures.

\section{Computing Heat and Water Budgets}

Water consumption at most power plants was modeled by heat and water budgets constructed in three independent steps: (1) the organization of systems within the plant was analyzed, and the plant was disaggregated where possible into modeling units containing a single generation type or cooling type, (2) condenser duty was estimated for groups of boilers and generators, and (3) water consumption was estimated for groups of boilers, generators, and cooling systems, using estimated condenser duty as input. Water consumption at solar thermal power plants was calculated on the basis of consumption coefficients found in the literature, because reported plant data were insufficient for construction of heat budgets.

To simplify computation of heat and water budgets, plants were disaggregated into groupings of boilers, generators, and cooling systems for which energy can be budgeted. For estimation of condenser duty, this required identifying groups of boilers and generators that are connected by the physical transfer of steam such that the fuel used by boilers in a particular boiler-generator group can be associated with the electricity generated by the generators in the same group. At nearly all plants, it was possible to construct boiler-generator groups with a single generation type (table 1). Because reported information on plant characteristics, the types and amounts of fuel consumed by a given plant, and electrical generation vary among generation types, separate heat-budget models were developed for each major generation type.

The water evaporated for cooling was estimated for each cooling-system group at each plant using a heat and water budget model with estimated condenser duty as input. A cooling-system group has one or more cooling systems and the associated boiler-generator groups that provide condenser duty to these cooling systems. Evaporation was modeled differently for cooling towers and surface-water cooling systems independently of generation type.

Disaggregation below the plant scale reduced the need to model mixed systems including multiple types of generation or cooling. Most thermoelectric water consumption was modeled as a single generation type transferring condenser duty to a single cooling type.

Many plants contain only a single cooling-system group, and others did not provide sufficient information to distinguish more than one cooling-system group. Nearly 500 plants reported no cooling system or operations information and so were necessarily treated as plants with a single cooling-system group. Where cooling-system groups included multiple types of cooling, the condenser duty was allocated between the two cooling models using professional judgement.

Error analysis established the upper and lower limit values for evaporation associated with cooling. It was assumed that errors from different sources were independent. Error from some sources such as environmental variables could be quantified, but other sources such as the estimation of exhaust heat at combined-cycle power plants contribute unknown amounts of error. 

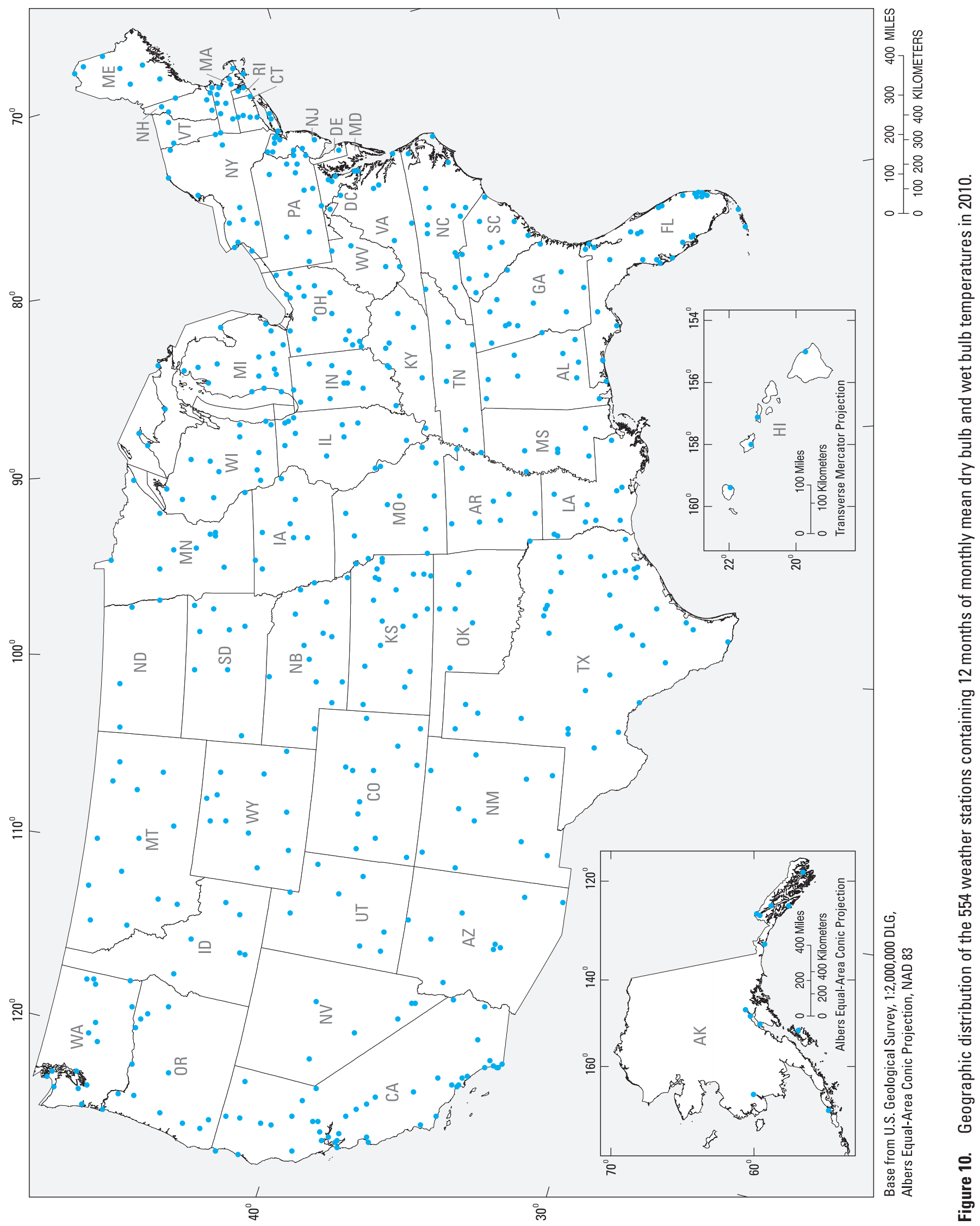


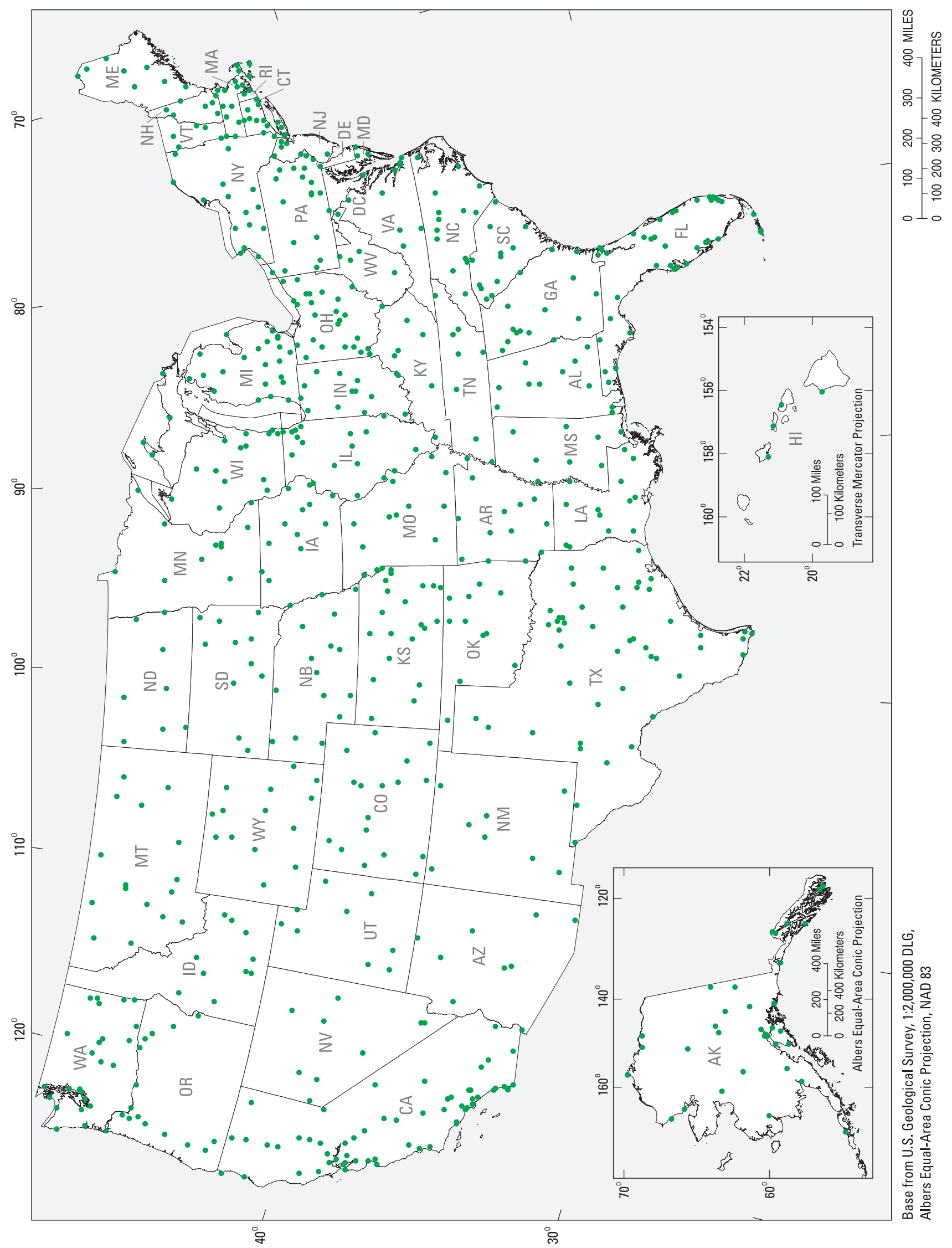

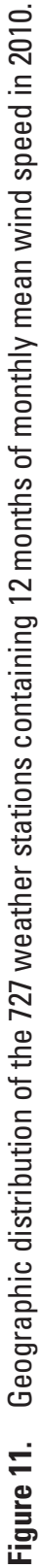



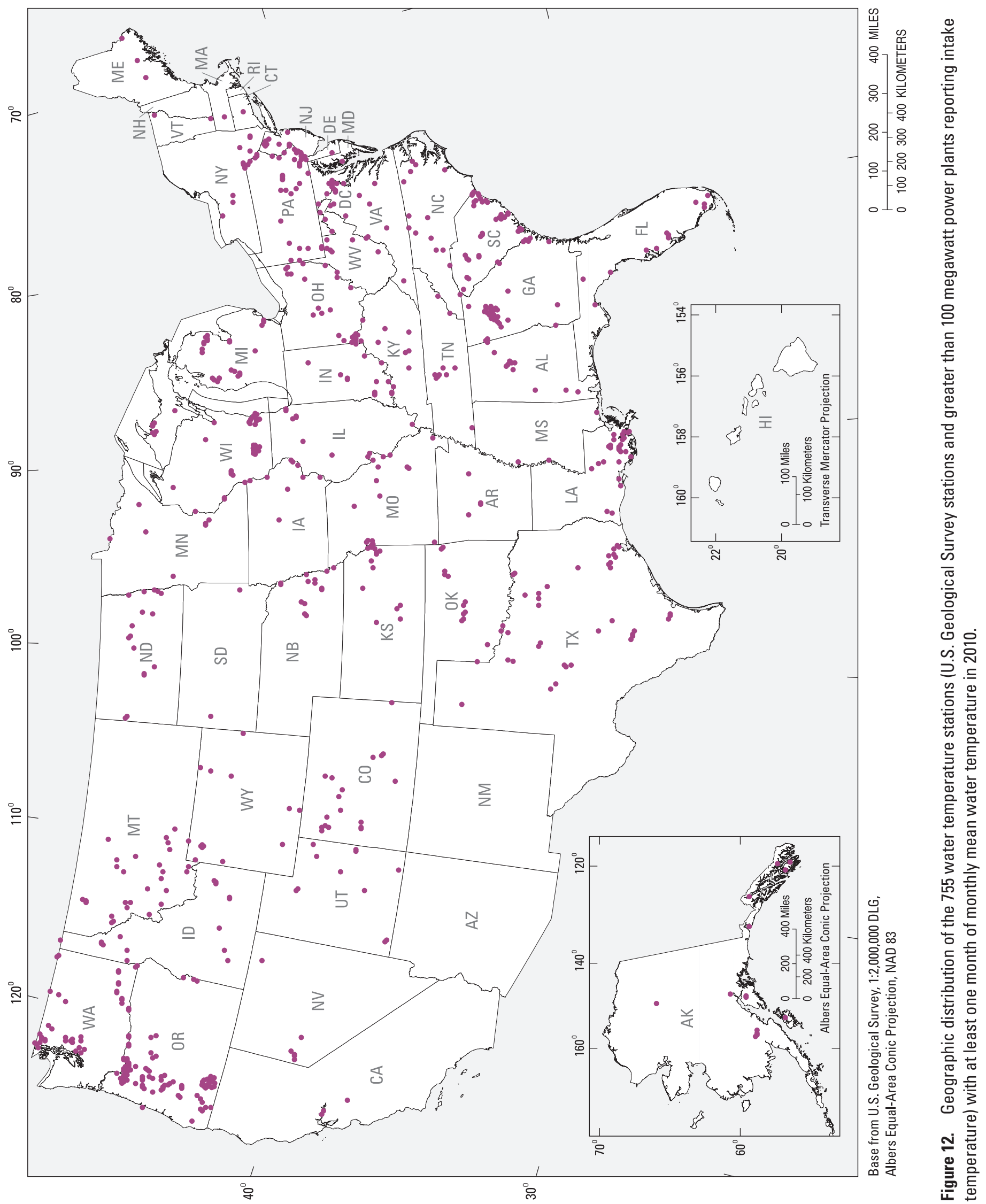


\section{Estimation of Condenser Duty by Generation Type}

Generator-boiler groups were assigned to five generationtype categories (table 1) based on energy source and prime mover:

1. Combustion steam groups have steam turbines (prime mover type ST; Appendix 2, table 2) and burn a variety of fuels as discussed below.

2. Combined-cycle groups have either a combination of combustion turbines and steam turbines driven by heat from the combustion turbines' exhaust, or a combinedcycle single-shaft turbine (prime mover types CT, CA, and CS, respectively). Nearly all of them burn primarily natural gas.

3. Nuclear groups have steam turbines and a nuclear energy source (energy source type NUC; Appendix 2, table 3).

4. Geothermal groups have steam turbines and a geothermal energy source (energy source type GEO).

5. Solar thermal groups have steam turbines and a solar energy source (energy source type SUN).

Condenser duty for boiler-generator groups of the first four types was estimated using heat budgets; condenser duty could not be estimated at solar-thermal plants.

The heat budget of a boiler-generator group can be described by the following equation:

$$
C D=T H-S L-N E-A L-X H
$$

where

$$
\begin{aligned}
C D & =\text { condenser duty; } \\
T H & =
\end{aligned}
$$

All terms are normally in units of million British thermal units (MMBtu) in conformity with EIA reporting.

Although equation (1) is broadly applicable to thermoelectric plants in general, methods for calculating the terms in this equation differ among generation types, reflecting differences in physical characteristics and available information. Whereas reasonable values of $T H$ are generally reported for combustion-steam and combined-cycle boiler-generator groups, reported values of $\mathrm{TH}$ for nuclear or geothermal boiler-generator groups are nominal, so $T H$ had to be estimated for these groups. Values of $S L$ were estimated by different methods for combustion-steam and combined-cycle boiler-generator groups, whereas $S L$ was zero for nuclear and geothermal boiler-generator groups. Reported values of $N E$ were used for all types of boiler-generator groups.

$A L$ was estimated at all plants by assuming that heat loss to the atmosphere is a constant 2 percent of total heat:

$$
A L=T H * 0.02
$$

Although values of $A L$ are reported to range from 1 percent to 4 percent for individual plants (U.S. Department of Energy, National Energy Technology Laboratory, 1999, 2007a; International Atomic Energy Agency, 2009; International Energy Agency, 2008; Electric Power Research Institute, 2011; U.S. Department of Energy, Energy Information Administration, 2013), there is not a strong basis for assigning different values of $A L$ to individual boiler-generator groups or to different generation types.

Combined heat and power plants report total fuel and electric fuel data. Total fuel is the actual fuel use, and the difference between total and electric fuel is the monthly amount of heat exported from the power plant to the associated heatusing process it supports. The exported heat was deducted from the condenser duty because this heat is dissipated by a second, non-thermoelectric process (fig. 13).

At all plants with exported heat, the exported heat $X H$ is defined by

$$
X H=T H-E H
$$

where $T H$ is the total heat introduced into the plant and $E H$ is the reported electric heat.

At several power plants, this deduction resulted in a budget with the total heat leaving the plant exceeding the total fuel heat entering the plant. This discrepancy indicates either misreported data or an inappropriately constructed heat budget. Due to lack of plant-specific data that would allow construction of a more detailed and accurate model, it was assumed that such plants export all their waste heat to the associated heat-using process.

\section{Combustion-Steam Generation}

Plants categorized as combustion steam use a variety of fuels or, less commonly, waste heat from outside the plant to power steam turbines. Combustion steam plants transfer a substantial amount of heat to the atmosphere in the exhaust gases. Most of these plants report heat production by boiler and electric generation by generator, allowing construction of heat budgets for individual boiler-generator associations. Reported boiler efficiencies appear realistic at most plants, allowing estimation of exhaust-gas heat on a plant by plant basis (fig. 14). For combustion steam boiler-generator groups, 


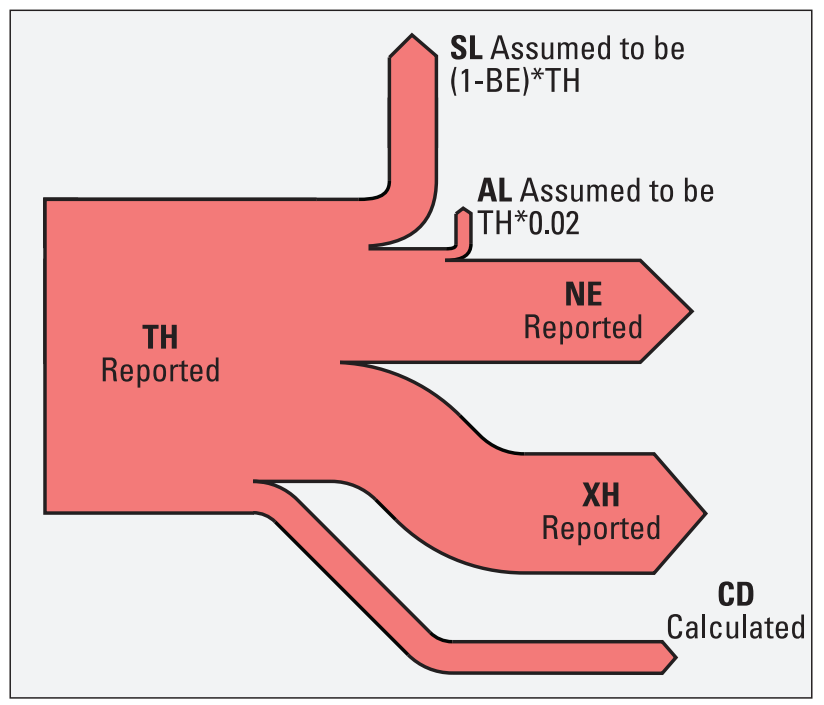

EXPLANATION
AL Heat lost to the air from plant equipment
BE Boiler efficiency at 100 percent load
CD Condenser duty
NE Net electrical generation
SL Heat lost through the stack (exhaust)
TH Total heat introduced into the plant
$\mathbf{X H}$ Heat exported from combined heat and power plants

Figure 13. Sankey diagram for an example combustion steam power plant with combined heat and power.

the reported value of $T H$ was used. Stack losses, $S L$, were estimated from reported or estimated boiler efficiency:

$$
S L=T H *(1-B E)
$$

where $B E$ is the reported or estimated boiler efficiency at 100 percent load.

Boiler efficiency was censored to range between 75 percent and 94 percent, based on the assumptions that (1) efficiencies above 94 percent are unlikely, because a minimum of about 6 percent of heat is lost up the stack (Sathyanathan, 2010), and (2) that a reported efficiency less than 75 percent more likely represents overall thermal efficiency (net electric generation divided by fuel heat) rather than boiler efficiency (steam heat divided by fuel heat).

Of the 1,997 steam-turbine (ST) boilers at 809 plants in the study set, 1,511 reported a boiler efficiency at 100 percent load, and 1,489 of these were between 75 percent and 94 percent. For each of these boilers, steam heat was estimated as total annual fuel heat times the reported boiler efficiency at 100 percent power. There were 1,413 boilers with reported efficiencies between 75 percent and 94 percent and non-zero fuel heat. At all of these, reported efficiency was used to calculate steam heat.

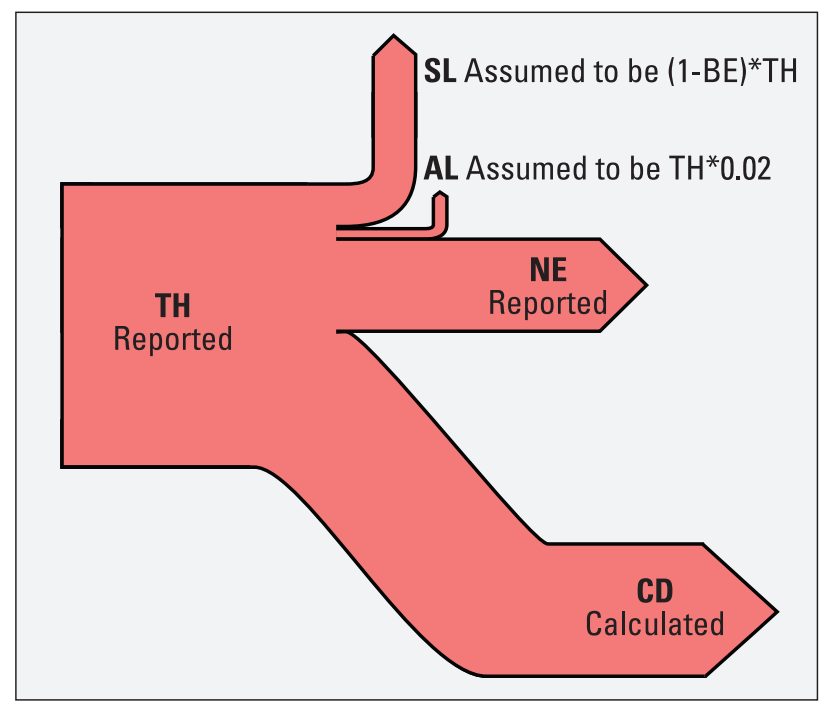

\section{EXPLANATION}

AL Heat lost to the air from plant equipment

BE Boiler efficiency at 100 percent load

CD Condenser duty

NE Net electrical generation

SL Heat lost through the stack (exhaust)

TH Total heat introduced into the plant

Figure 14. Sankey diagram for combustion steam plants.

Of the various fuels that power steam turbines, 10 fuels were determined to be dominant: bituminous coal (BIT), black liquor (BLQ), distillate fuel oil (DFO), lignite (LIG), natural gas (NG), petroleum coke (PC), residual fuel oil (RFO), subbituminous coal (SUB), waste, other coal (WC), and wood, wood-waste solids (WDS); 1,311 boilers had at least 75 percent of their fuel heat coming from one of these fuels. A weighted average boiler efficiency was calculated for each of these 10 fuels as the total estimated steam heat in the fuel category divided by the total reported fuel heat. This weighted efficiency was dominated by the boilers with the most fuel heat. Unweighted average efficiencies differ from weighted efficiencies for each fuel, but except for RFO these differences were less than 1 percent (table 3).

There were 484 ST boilers with fuel heat but no valid reported boiler efficiency. At 316 of these boilers, the dominant fuel was one for which an average efficiency had been determined, and the boiler efficiency was assumed to be the average value for the dominant fuel. At 168 boilers that primarily burned other fuels - agriculture crop by-products/ straw energy crops (AB), blast-furnace gas (BFG), landfill gas (LFG), municipal solid waste-biogenic (MSB), other biomass solids (OBS), other gas (OG), and tires (TDF) - the weighted average for all 1,311 boilers was used (table 3 ). 


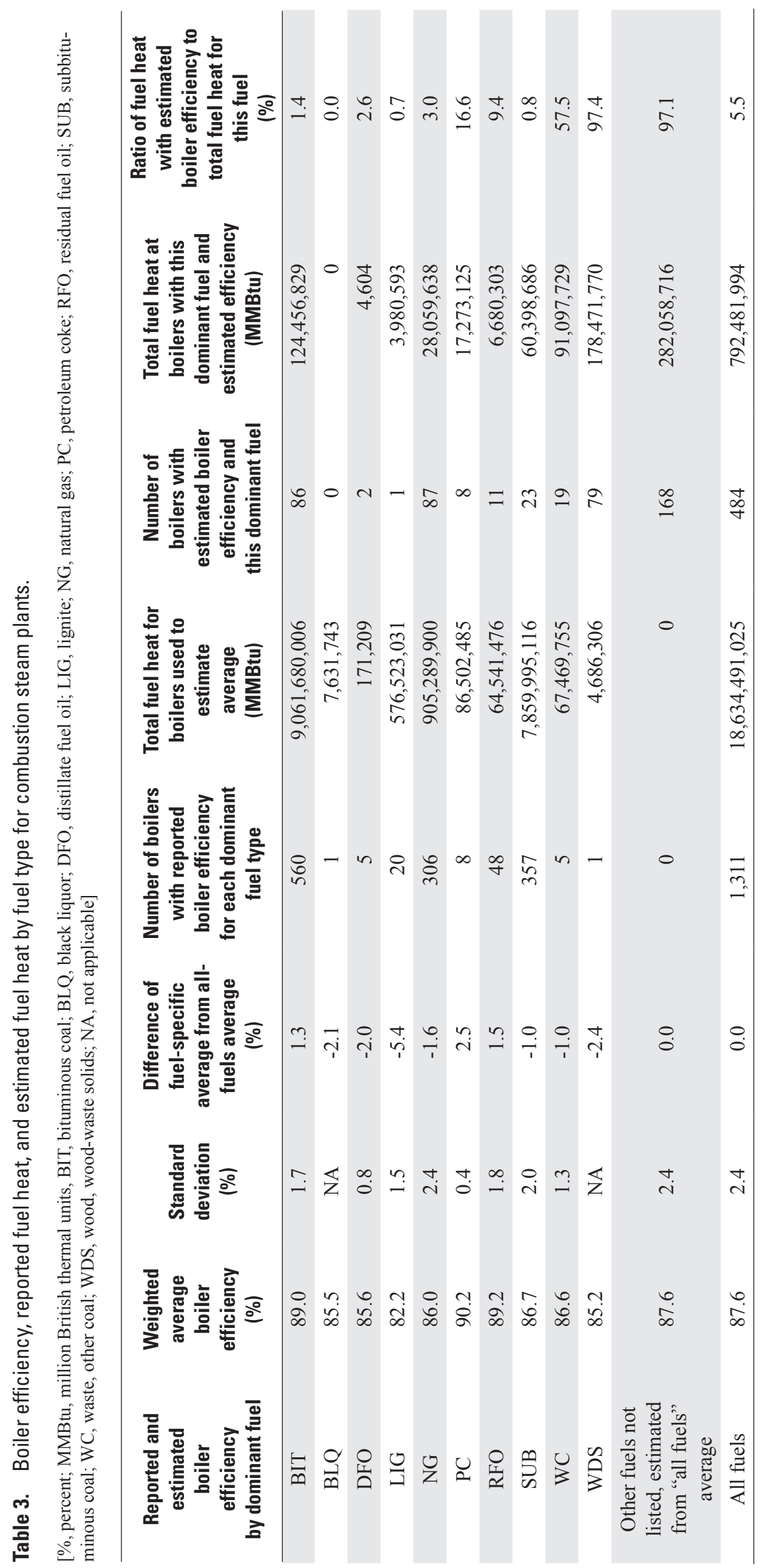


One plant (EIA plant code 50271, Appendix 1) did not report net electrical generation, but did report heat used for electrical generation. At this plant, the heat used for electrical generation was divided by the heat rate derived from the National Electric Energy Data System (NEEDS) v4.10 (U.S. Environmental Protection Agency, 2006; Appendix 3) to estimate net electrical generation.

Reported boiler efficiency at 100 percent load is assumed to be accurate, but it may be the nameplate efficiency under conditions specified by the boiler supplier, not the actual efficiency achieved in the boiler during operation in 2010. Reported differences between efficiency at 50 percent and 100 percent load have a mean of near zero and a standard deviation of about 2 percent; most electricity is generated nearer to 100 percent load than 50 percent load, but plants operated intermittently or at partial load have an error in boiler efficiency that may be on the scale of this standard deviation.

For boilers without realistic reported efficiencies, the estimated efficiencies that were used are subject to greater error. Fuel categories containing more than 20 boilers had standard deviations of efficiency from 1.7 percent to 2.4 percent, suggesting an imprecision of about plus or minus 5 percent in addition to imprecision in the reported efficiencies as surrogates for actual efficiencies. There were relatively few plants with this additional error, so it has little effect on condenser duty aggregated over fuel categories.

\section{Combined-Cycle Generation}

Combined-cycle plants include both combustion turbines and steam turbines working in tandem. Natural gas provided about 99 percent of total fuel heat at combined-cycle plants. About two-thirds of a combined-cycle plant's electric output is generated in its combustion turbine(s). Exhaust heat from the combustion turbine(s) is used to boil water for the steam turbine and generates about one-third of the plant's electric output. The efficiency of combined-cycle plants is generally high. The shares of fuel heat leaving the plant as both electricity and heat in the exhaust are higher than in other plants, so the share of fuel heat that becomes condenser duty is smaller. Fuel use and generation associated with the combustion turbines are reported at the plant level, so the heat budget must be constructed for the plant as a whole (fig. 15). At combinedcycle plants, reported values of $T H$ were used.

The reported boiler efficiencies for combined-cycle plants were not used in heat budgets. The boilers of prime mover type CA (Appendix 2, table 2) reporting boiler efficiency on the EIA 860 form are actually heat-recovery steam generators (HRSGs) using exhaust from combustion turbines to generate steam. Some have supplementary burners that add heat to this exhaust. Many combined-cycle steam boilers report efficiencies greater than 94 percent, whereas many others report efficiencies below 75 percent. Attempts to produce heat budgets based on these reported efficiencies resulted in contradictory results. In some cases, it was impossible to account for all of the fuel heat; in others, the model results in more heat leaving the system than the total fuel heat entering the system. Rather than use reported boiler efficiency to estimate $S L$, it was assumed that 20 percent of the fuel heat leaves combinedcycle plants in their exhaust gases:

$$
S L=T H * 0.2
$$

This assumption is based on detailed heat budgets for three plants (U.S. Department of Energy, National Energy Technology Laboratory, 1999, 2007a) and is shared by Rutberg and others (2011). The three example plants are large, new plants with thermal efficiencies above 50 percent, at the upper end of the range for operating combined-cycle plants in 2010. Many existing plants are smaller, older, and less thermally efficient. Some plants were originally combustion turbines without heat recovery to which a HRSG and steam turbine have been retrofitted. The accuracy of the estimated 20-percent stack loss across the full range of combined-cycle plants has not been established.

As at other plants, the amount of heat leaving the plant by conduction to the air, most of it representing losses from fans and pumps, was assumed to be 2 percent of fuel heat. Uncertainty in this number has a larger effect on condenser duty at combined-cycle plants than at other plants because condenser duty is a smaller percentage of fuel heat at combined-cycle plants than at other plants.

\section{Nuclear Generation}

In nuclear power plants, no heat leaves the plant in exhaust gases, and more heat leaves the plant as condenser duty than in combustion steam plants. The total heat values reported by EIA were not used, because the data are evidently estimated from net generation using a nominal heat rate of 10,460 Btu per kilowatt hour, corresponding to a nominal thermal efficiency of 32.6 percent at all plants. The actual reactor heat at each plant was estimated by assuming that the plant operator keeps the reactor close to its maximum permitted thermal power. This assumption results in a unique estimated thermal efficiency at each nuclear boiler-generator group (fig. 16).

It was assumed that the permitted thermal reactor outputs listed by the U.S. Nuclear Regulatory Commission

(U.S. Nuclear Regulatory Commission, 2009, 2010, 2011) are used as operational targets by operators, and that the operators generally stay close to those limits (Joshua Trembley, Exelon, oral commun., 2012; James Riley, Nuclear Energy Institute, oral commun., 2012). This assumption produces the lowest reasonable thermal efficiency. Exceedances of maximum permitted thermal reactor power were assumed not to occur.

Monthly average power was calculated as reported net generation divided by the number of hours in each month. The ratio of monthly average power divided by the permitted maximum thermal output at each unit was calculated, and it was assumed that the maximum value of this ratio is the 


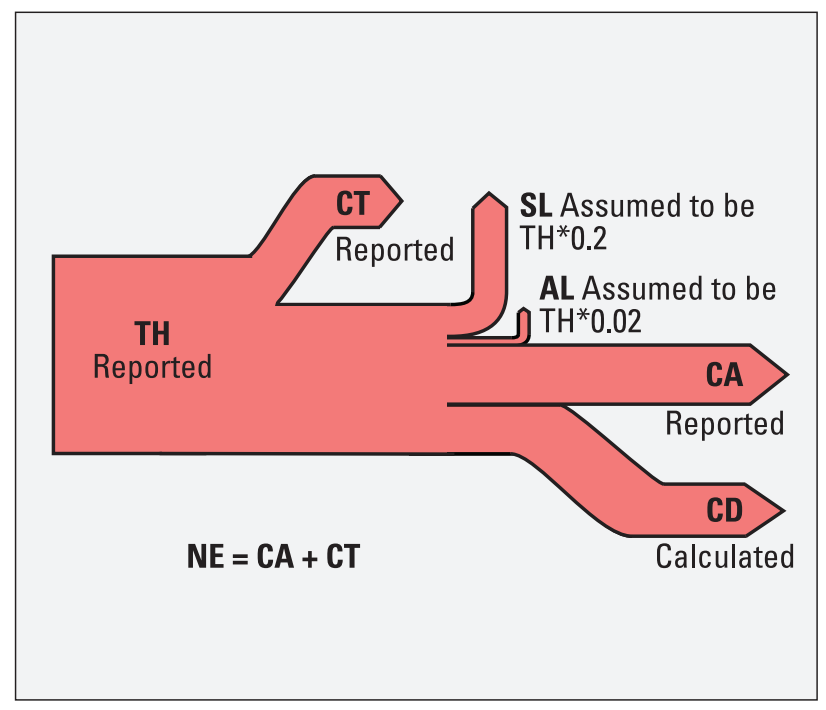

\section{EXPLANATION}

AL Heat lost to the air from plant equipment

CA Combined cycle, steam plant

CD Condenser duty

CT Combined cycle, combustion turbine

NE Net electrical generation

SL Heat lost through the stack (exhaust)

TH Total heat introduced into the plant

Figure 15. Sankey diagram for combined cycle plants.

peak thermal efficiency for the unit. These maxima occurred in November, December, January, or February at nearly all units. Using the assumptions described above, mean thermal efficiency for nuclear power plants was estimated to be 32.9 percent, and thermal efficiency at individual plants ranged from 29.4 percent to 35.4 percent.

The monthly average power tended to decrease systematically in the summer, generally reflecting the difference between reported winter and summer maximum capacity. It was assumed that this decrease was caused by operators reducing reactor power during the summer to accommodate reduced cooling system capacity. Following this assumption, total reactor heat in each month was estimated by net generation divided by the peak efficiency. Estimated condenser duties ranged from 63 to 69 percent of total reactor heat and 176 to 233 percent of net generation.

An alternative assumption would be that thermal efficiency decreases in summer while thermal power remains near the permitted maximum. This approach would yield an estimated summer decline in thermal efficiency that is specific to each plant and based on a reported value. This decline was in the range of 0 percent to 6.5 percent from winter to summer, with a median of 2.5 percent. Using this approach would increase annual condenser duty (and water consumption) by a maximum of 3 percent and a median of 2 percent at individual nuclear units. Monthly values of condenser duty would remain about the same in winter, but would increase by a maximum

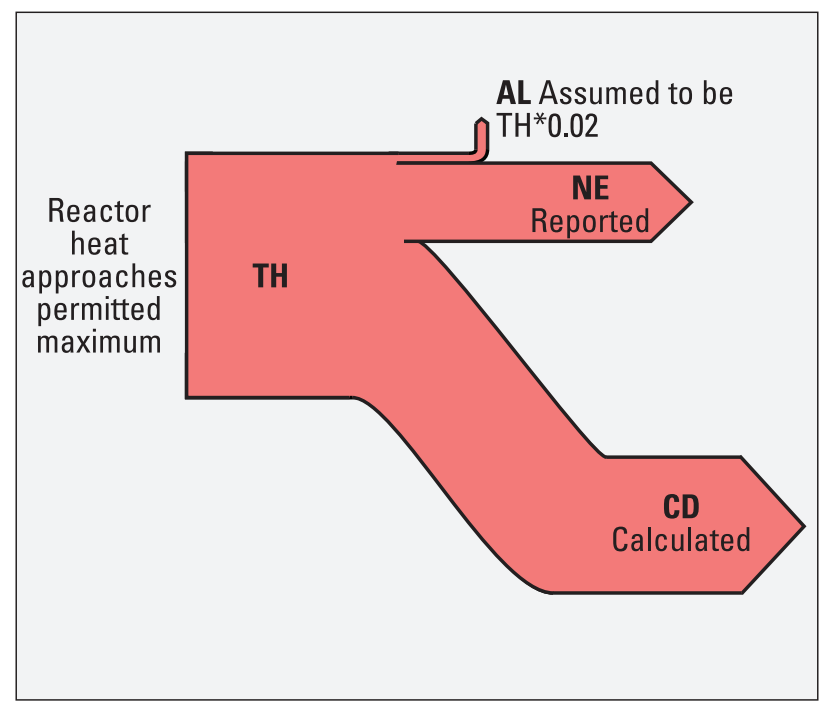

\section{EXPLANATION}

AL Heat lost to the air from plant equipment

CD Condenser duty

NE Net electrical generation

TH Total heat introduced into the plant

Figure 16. Sankey diagram for nuclear plants.

of 10 percent and a median of 3 percent in the summer. Given the lack of specific information about reactor operations and the small effect of this more detailed approach at most plants, the simpler assumption of constant thermal efficiency was retained. At nuclear boiler-generator groups, total heat was estimated on the basis of the estimated thermal efficiency:

$$
T H=N E / T E
$$

where $T E$ is the thermal efficiency estimated, as discussed above.

\section{Geothermal Generation}

Geothermal plants are analytically similar to nuclear plants although they use different heat sources (fig. 17). Their heat and generation are reported by fuel type at the plant level. Total heat reported by the EIA is nominal, evidently based on an assumed 35-percent thermal efficiency. In NEEDS v.4.10 (U.S. Environmental Protection Agency, 2006; Appendix 3), the thermal efficiency associated with geothermal plants is about 16 percent, lower and more realistic than the 35 percent used by EIA. Although actual efficiencies realized at geothermal plants are generally lower and depend on the temperature of the geothermal resource (DiPippo, 2004; Dagdas and others, 2005; Golub and others, 2006; Franco and Villani, 2009; 


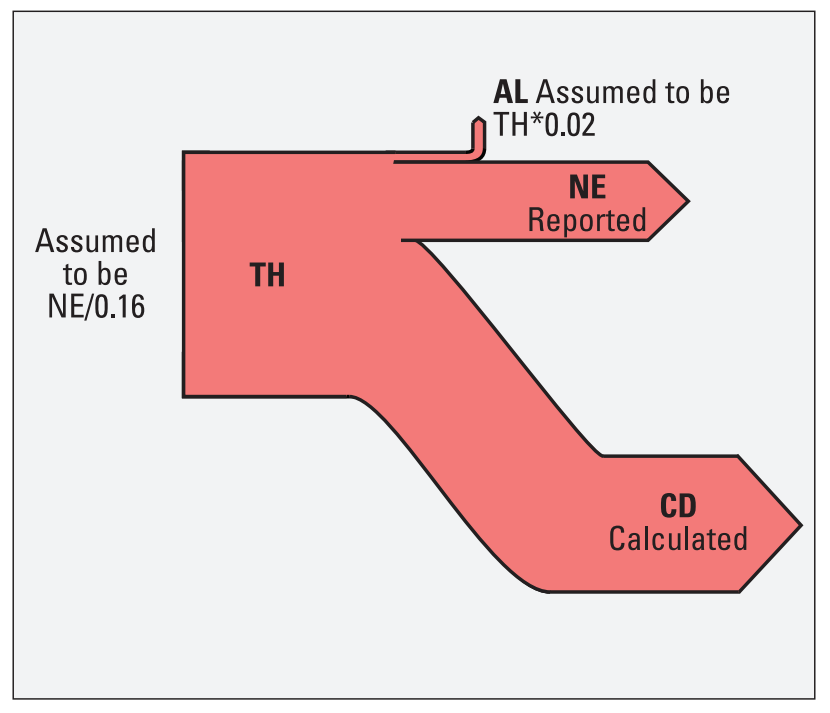

EXPLANATION

AL Heat lost to the air from plant equipment
CD Condenser duty
NE Net electrical generation
TH Total heat introduced into the plant

Figure 17. Sankey diagram for geothermal plants.

Drader and others, 2012), total heat at geothermal plants was estimated as net generation divided by the NEEDS thermal efficiency:

$$
T H=N E / 0.16
$$

where 0.16 is the estimated thermal efficiency for this type of plant and $N E$ is net electrical generation.

The methods used in this study for geothermal power plants are approximate and insensitive to the characteristics of individual plants; therefore, estimates of condenser duty are imprecise, but are believed to be less biased than if the reported total-heat values had been used. As geothermal plants are few and generally small, this imprecision has little impact on regional sums of consumption. Geothermal electric water consumption is about 2 percent of all U.S. thermoelectric water consumption.

For geothermal plants, published water-consumption coefficients vary over a range of more than three orders of magnitude (Ashwood and Bharathan, 2011; Clark and others, 2010; Dennen and others, 2007; Kagel and others, 2005; Larson and others, 2007; Mishra and others, 2011), and "definitional noise" (Dziegielewski and Kiefer, 2010) makes it difficult to generalize typical values. As an experiment, published values of water use were substituted at the plants they were derived from and at plants with similar cooling technology. These substitutions changed water consumption at plants representing 75 percent of the geothermal generation, reducing consumption to zero at some plants and increasing it by a factor of 6 at others. The net effect on water use by the geothermal electric sector was to increase it by 35 percent. This approach did not appear to be substantially better than using the NEEDS heat rate as described above, and was not used to produce the final estimates.

\section{Estimating Thermoelectric Evaporation by Cooling-System Type}

Heat and water budgets provide a transparent means to constrain estimates of evaporation from thermoelectric plants within thermodynamically realistic values. The heat and water budgets presented in this report require estimates of monthly condenser duty and information about cooling system characteristics and environmental variables as input. Monthly estimates of condenser duty are obtained using the method described above, based on a given plant's generation type. Simple heat and water budget models were developed for the two cooling-system types that use substantial amounts of freshwater: (1) wet cooling towers, and (2) surface-water cooling systems. Both cooling system models require monthly averages of dry bulb air temperature, wet bulb air temperature, ambient surface-water temperature, and wind speed. For surface-water cooling systems, the parameters used to calculate one variable in the model, the wind function, are given different values for ponds, lakes, and rivers.

Most thermoelectric plants use evaporative cooling towers in which more than 60 percent (Solley and others, 1998) of the rejected heat typically leaves the tower as latent heat in evaporated water and the rest as sensible heat that increases the temperature of the air passing through the cooling tower. Evaporation in wet towers depends on tower design, condenser duty, and wet bulb and dry bulb air temperatures.

A single heat and water budget model was developed for all surface-water cooling systems, with somewhat different input data for recirculating ponds and once-through systems. The basic model for surface-water cooling systems takes as input water-surface area and monthly estimates of condenser duty, ambient water temperature, and wind speed. For recirculating ponds, water-surface area is equal to the surface area of the pond; for once-through systems, the water-surface area nominally represents the surface area of the plume created by the return flow of heated water that has passed through the condenser. Plants with once-through cooling (including ponds and canals without recirculation) typically report low water consumption within the plant, but evaporation from the plume represents consumption outside the plant boundaries that can account for more than half of the condenser duty (Ward, 1980; Huston, 1975). With once-through cooling, the receiving water body is generally not as hot as a typical cooling pond, so the percentage of heat that drives evaporation is lower. 
Many plants have both towers and some form of watersurface cooling. These cooling-system types have different consumption rates relative to generation, so allocation of the available condenser duty among the available cooling-system types influences estimated consumption. At plants where the disparate cooling systems were connected to different boiler-generator groups, or where single-type cooling systems reported operations separately, distributing excess heat among different cooling-system types was straightforward.

At plants reporting one cooling system that used multiple types of cooling, plants with at least some boilers connected to multiple cooling systems of different types, or plants not reporting cooling operations, the allocation of condenser duty was estimated using professional judgment based on known plant characteristics. Estimated consumption at all such plants represented 17 percent of total estimated thermoelectric water consumption. These estimates were bracketed by estimates of maximum and minimum plausible thermoelectric water consumption at the plant scale. The maximum plausible consumption was estimated allocating all condenser duty to the cooling-system type with the most consumption (typically towers), and the minimum was estimated by allocating all condenser duty to the type with the least consumption (typically once-through systems).

\section{Estimating Evaporation from Cooling Towers}

The method described by Leung and Moore (1970, 1971) was used as the primary method for estimating evaporation from cooling towers. This method uses a heat balance through the tower, with the key assumption that the air leaving the tower is saturated with water vapor. Estimates made using the Leung and Moore method are likely accurate at baseload plants within plus or minus 5-15 percent (Strauss, 1978; Hu and others, 1978, 1981). Sensitivity testing confirmed that the model results are sensitive to wet bulb and, to a lesser extent, dry bulb air temperature and to plant elevation and design characteristics, but not to the temperature of water added to the tower to replace evaporated water (makeup water). A single model was used for all wet towers because the reported information on tower characteristics and operations did not support finer distinctions or justify using multiple models. To allow for the range of performance, a suite of tower characteristics was modeled and the maximum, minimum, and median evaporation for this suite were reported.

About two-thirds of thermoelectric plants in the plant Master List use wet recirculating cooling towers, and since 1980 , nearly all new power plants have used wet towers. In wet cooling towers, hot water coming from the condenser moves slowly downward through a volume of fill, while air flows through the same volume. The fill takes many forms, but always is a structure of stationary elements that slow the descent of water and disperse it to maximize water-surface area, while minimizing resistance to air flow. The cooling water accumulates in a basin under the fill, from where it is pumped back to the condenser.
The air may be moved mechanically by fans at the air inlet (forced draft) or outlet (induced draft) or by convection (natural draft) (United Nations Environment Programme, 2006). These three cooling tower types encompass a range of consumption rates. Natural-draft (convection draft) towers have a wide variability in the mass ratio of water flow to dry air flow $(\mathrm{L} / \mathrm{G})$, whereas mechanical draft towers have near constant $\mathrm{L} / \mathrm{G}$.

The temperature to which the tower can cool the warm water from the condenser is limited by the wet bulb temperature of the ambient air. In a tower receiving warmed water, the water in the basin under it is warmer than the wet bulb temperature by an amount called the approach (Cheremisinoff and Cheremisinoff, 1981). The difference in temperature between the hot water entering the tower and the cooler water in the basin is called the range. The $\mathrm{L} / \mathrm{G}$ ratio has a strong influence on these temperature characteristics. A dimensionless ratio called the Merkel tower characteristic describes the heat transfer process and is proportional to $C^{*}(L / G)^{n}$, where $C$ and $n$ are empirical constants that depend on tower design.

The approach, the range, and the three terms that define the Merkel tower characteristic influence the results of the Leung and Moore model, but values of these variables are not reported to the EIA. Rather than select a single "typical" set of values for these variables, 34 combinations of values were modeled; some of these combinations of values may not correspond to real towers. Tower designs were chosen to cover an approach from 5 to $15^{\circ} \mathrm{F}$, a range of 10 to $25^{\circ} \mathrm{F}$ (Cheremisinoff and Cheremisinoff, 1981), an L/G of 1 to 2 , a coefficient "C" of 1.6 to 2.5 , and an exponent "n" of -0.6 to -0.8 .

The Merkel tower characteristic was determined for each example tower design and was constrained between about 1 and 2.5. Evaporation ratios under design conditions ranged from 87 percent to 99 percent, with a median of 88 percent, and were generally higher for towers with low approach, low range, and low $\mathrm{L} / \mathrm{G}$.

The basic equation for the method is as follows:

$$
L_{m u}=\frac{Q_{p}}{\left(\frac{H_{a 2}-H_{a 1}}{\omega_{2}-\omega_{1}}\right)-h_{m u}}
$$

where

$$
\begin{aligned}
L_{m u} & =\text { the mass of the water evaporated; } \\
Q_{p} & =\text { the net heat rejected in the cooling tower; } \\
H_{\mathrm{a} 1} & =\text { the specific heat of inflow air; } \\
H_{\mathrm{a} 2} & =\text { the specific heat of outflow air; } \\
\omega_{1} & =\text { the specific vapor content of inflow air; } \\
\omega_{2} & =\text { the specific vapor content of outflow air; } \\
& \quad \text { and } \\
h_{m u} & =\text { the specific heat of the makeup water. }
\end{aligned}
$$

The quantity $\left(\frac{H_{a 2}-H_{a 1}}{\omega_{2}-\omega_{1}}\right)-h_{m u}$ is the net heat added per mass of water evaporated. 
As both $H_{\mathrm{a} 2}$ and $\omega_{2}$ are unknown, it is necessary to assume that the air leaving the cooling tower is saturated with water vapor. This allows $H_{\mathrm{a} 2}$ to be defined in terms of the other variables, and the equation is solved iteratively to estimate $L_{m u}$.

For some plants, winter operations present a special case requiring adjustment of the method. When the wet bulb temperature is at or below freezing, cooling tower operations are changed to prevent ice formation in the fill, usually by decreasing air flow or concentrating hot water flow in one area of the fill. The effect of these changes is to keep the coldest water temperature in the fill at $40^{\circ} \mathrm{F}\left(4.4^{\circ} \mathrm{C}\right)$ or above; published recommendations for minimum water temperature in the basin below the tower range from $40^{\circ} \mathrm{F}\left(4.4^{\circ} \mathrm{C}\right)$ to $50^{\circ} \mathrm{F}$ $\left(10^{\circ} \mathrm{C}\right)$ (Cheremisinoff and Cheremisinoff, 1981; The Cooling Tower Company, L.C., 2005; Cooling Technology Institute, 2010; Evapco, 2010; Marley, 2012). The best way to simulate winter operations within the simple structure of the Leung and Moore model was to artificially limit both wet bulb and dry bulb temperatures to a minimum of $35^{\circ} \mathrm{F}\left(1.7^{\circ} \mathrm{C}\right)$. The choice of $35^{\circ} \mathrm{F}\left(1.7^{\circ} \mathrm{C}\right)$ was conservative in the sense that a lower temperature could have been justified (Cheremisinoff and Cheremisinoff, 1981) and would have produced lower winter evaporation. Without this artificial minimum temperature, evaporation ratios become unrealistically low. This rough approximation adds uncertainty to the estimates, but winter operational changes vary among tower types and individual operators, so adding complexity to the model is unjustified.

The model was run for the suite of tower designs at many pairs of dry bulb and wet bulb temperatures spanning the range of conditions encountered at U.S. power plants. The estimated median, minimum, and maximum evaporation ratios changed smoothly over this temperature field, and linear interpolation was used to estimate nominal median, minimum, and maximum evaporation ratios at sea level, based on monthly average dry bulb and wet bulb temperatures for 2010 at U.S. power plants with wet towers. For each combination of dry bulb and wet bulb temperatures, the rates of decrease in median, minimum, and maximum evaporation ratios with the elevation of the plant were found to be approximately linear. These linear rates of decrease were estimated by interpolation based on dry bulb and wet bulb air temperatures for each month and were used in combination with the plant elevation to adjust the median, minimum, and maximum evaporation ratio for each month.

The method of Rutberg and others (2011) was used to generate an alternative estimate of the maximum evaporation ratio at each plant location. Rutberg and others (2011) raised the issue that the air leaving the cooling tower may be unsaturated during hot weather and supersaturated during cold weather, leading the Leung and Moore method to underestimate winter evaporation and overestimate summer evaporation. They developed a simplified method for estimating cooling-tower evaporation based solely on dry bulb air temperature:

$$
E R=1-\left[\begin{array}{l}
\left(-0.000279 T_{a}^{3}+0.00109 T_{a}^{2}\right. \\
\left.-0.345 T_{a}+26.7\right) / 100
\end{array}\right]
$$

where $E R$ is the ratio of the heat used to evaporate water to the total heat discharged through the tower, and $T_{a}$ is the monthly average dry bulb air temperature in ${ }^{\circ} \mathrm{C}$.

This equation produces estimates of evaporation that are higher than the highest estimates made with the Leung and Moore method in cool months. This equation was used as a supplemental method for estimating the upper limiting value of $E R$ when its prediction exceeded the maximum Leung and Moore estimate. With the Rutberg and others estimate incorporated as an alternate maximum, the range between minimum and maximum estimated values of evaporation ratio exceeded the plus or minus 15 percent cited by Hu and others (1981) as the accuracy of the Leung and Moore method. More detailed modeling based on tower characteristics that are not reported to EIA might yield a different range of actual evaporation ratios.

The product of the estimated evaporation ratio and the estimated condenser duty is the estimated heat of evaporation for a given month. This is converted to a weight of water based on the latent heat of vaporization, then to a volume per month. The product of the maximum evaporation ratio and the maximum condenser duty gives the maximum likely evaporation, and the product of the minimum evaporation ratio and the minimum condenser duty gives the minimum likely evaporation.

\section{Estimating Forced Evaporation from Surface Water}

A simple heat balance model was used to estimate the evaporation ratio for surface-water cooling systems. This model, first developed by Harbeck (1964) for cooling ponds, was improved by Ward (1980). The model uses monthly data that can be estimated at most power plants: average natural water temperature, average wind speed, and the water-surface area over which heat is dissipated. This model is similar to the one presented by Diehl (2011).

Surface-water cooling systems draw water from lakes, rivers, and recirculating and once-through ponds. For the heat balance model, these water bodies were classified for analysis as lakes, rivers, and ponds, with many plants that reported lake to EIA classified in this analysis as pond due to high heat loading. The same model was used for all three types of water bodies, with each type using different parameters in the function relating wind to mass transfer away from the water surface.

Heat loading is estimated as the ratio of condenser duty to the area over which heat is dissipated. This area was estimated to be the entire area of ponds or small lakes, where this ratio produced heat-loading estimates exceeding $0.35 \mathrm{MW}$ per acre (about 0.002 calories per square centimeter per second $\left[\left(\mathrm{cal} /\left(\mathrm{cm}^{2} / \mathrm{s}\right)\right]\right)$. For lakes that were larger relative to condenser duty, a heat loading of $0.1 \mathrm{MW}$ per acre (about 0.0006 
$\left.\left[\mathrm{cal} /\left(\mathrm{cm}^{2} / \mathrm{s}\right)\right]\right)$ was assumed; forced evaporation is not sensitive to small differences in heat loading. For rivers, a heat loading of $0.2 \mathrm{MW}$ per acre (about $0.001\left[\mathrm{cal} /\left(\mathrm{cm}^{2} / \mathrm{s}\right)\right]$ ) was assumed.

This model does not estimate the non-forced evaporation from recirculating cooling ponds or reservoirs that would take place in the absence of added heat from the power plant's condenser; only the forced evaporation is modeled. Consumption is sometimes defined as including water withdrawn that is no longer available to be returned to a water source or all cooling water lost to evaporation (U.S. Government Accountability Office, 2009), implicitly including unforced evaporation from recirculating cooling ponds. Under such a definition, water consumption at plants with recirculating cooling ponds would be larger than the forced evaporation, with greater increases for ponds and reservoirs with low added heat per area, and in hot, dry regions.

Equations for heat loss were solved for both the natural and heated water temperatures, with the estimated heatedwater temperature adjusted iteratively until the difference in heat loss at the two temperatures was equal to the added heat from the power plant. Monthly average values were used for environmental variables and monthly estimates of the percent of condenser duty that drives evaporation (evaporation ratio) were produced. In the following equations, the units used by Ward (1980) are preserved to facilitate comparison to his and Harbeck's (1964) publications.

The method used in this study for estimating forced evaporation is based on that of Ward (1980), with a few key revisions:

1. A heat loading (condenser duty per area) is estimated or measured, as discussed above.

2. A natural water temperature is estimated based on available water-temperature data.

3. The relevant heat balance equations are solved iteratively to estimate a heated water temperature.

4. The percent forced evaporation is given by the ratio of the difference in evaporation at the two water temperatures to the sum of differences in evaporation, conduction, and radiation at the two water temperatures.

The total heat loss from a water surface is the sum of heat loss through evaporation, conduction, and radiation expressed in terms of energy flux per unit area:

$$
H(T)=E(T)+C(T)+R(T)
$$

where $H(T)$ is heat loss from the water surface, $E(T)$ is heat loss through evaporation, $C(T)$ is conduction, and $R(T)$ is radiation, all in $\left[\mathrm{cal} /\left(\mathrm{cm}^{2} / \mathrm{s}\right)\right]$, and $T$ is water temperature in ${ }^{\circ} \mathrm{C}$.

The difference in heat loss between the natural water temperature $(T)$ and heated water temperature $\left(T^{\prime}\right)$, equal to the heat loading, is given by the sum of differences in evaporation, conduction, and radiation at these two temperatures:

$$
\begin{aligned}
& {\left[H\left(T^{\prime}\right)-H(T)\right]=\left[E\left(T^{\prime}\right)-E(T)\right]+} \\
& {\left[C\left(T^{\prime}\right)-C(T)\right]+\left[R\left(T^{\prime}\right)-R(T)\right]}
\end{aligned}
$$

or:

$$
\Delta H=\Delta E+\Delta C+\Delta R
$$

Evaporation is given by:

$$
E(T)=\rho L f(W)\left[e(T)-e_{a}\right]
$$

where $\rho$ is water density in grams per cubic centimeter, $L$ is the latent heat of vaporization in calories per gram, $e(T)$ is the saturation vapor pressure in millibars at water-surface temperature $T, e_{a}$ is the vapor pressure of the overlying atmosphere in millibars, and $f(W)$ is the wind function, for example the wind function of Ward (1980):

$$
f(W)=7.0 * 10^{-8}(W)
$$

where $W$ is wind speed in miles per hour. The values of $\rho$ and $L$ change little from $T$ to $T^{\prime}$; the effect of this change on forced evaporation can be ignored (Ward, 1980). The difference in evaporation from $T$ to $T^{\prime}$ is given by:

$$
\Delta E=\rho L f(W)\left[e(T)-e\left(T^{\prime}\right)\right]
$$

Conduction is given by:

$$
C(T)=f(W)\left(\frac{\rho p c_{p}}{\varepsilon}\right)\left(T-T_{a}\right)
$$

where $p$ is atmospheric pressure in millibars, $c_{p}$ is the specific heat of air at a constant pressure, 0.24 calories per gram per degrees Kelvin, $\varepsilon$ is the molecular weight ratio of water vapor to dry air, and $T_{a}$ is air temperature in degrees Celsius. The difference in conduction from $T$ to $T^{\prime}$ is given by:

$$
\Delta C=f(W)\left(\frac{\rho p c_{p}}{\varepsilon}\right)\left(T^{\prime}-T\right)
$$

Radiation is given by:

$$
R(T)=\varepsilon_{r} \sigma(T+273)^{4}
$$

where $\sigma$ is the Stefan-Boltzman constant $\left(1.17 * 10^{-7}\right.$ calories per square centimeter per degrees Kelvin to the fourth power per day) and $\varepsilon_{r}$ is the emissivity of the water surface, 0.97 . The difference in radiation from $T$ to $T^{\prime}$ is given by:

$$
R(T)=\varepsilon_{r} \sigma\left[\left(T^{\prime}+273.15\right)^{4}-(T+273.15)^{4}\right]
$$


The difference in the heat loss at the two temperatures $\Delta H$ is set equal to the condenser duty by iteratively adjusting the heated water temperature $\left(T^{\prime}\right)$. The ratio of forced evaporation to condenser duty is given by:

$$
E R=\Delta E / \Delta H
$$

Ward (1980) demonstrated that additional heat losses through evaporation, conduction, and radiation are approximately linear functions of an imposed increase in water temperature, and based on this approximation, the ratio of increased evaporation to the total increase in heat loss is a function of only water temperature and wind speed (fig. 18). If the imposed heat load is distributed over an assumed area, the heated temperature can be solved for iteratively, and the share of evaporation in the increased heat dissipation can be calculated directly. This solution is insensitive to air temperature, humidity, and the variation in water density and vapor pressure between the two temperatures.

The wind function is a coefficient of vertical mixing, and is used to calibrate heat budget models to measured evaporation data. A wide variety of wind functions have been determined for a variety of settings, including cooling ponds, natural lakes and ponds, rivers, and irrigation canals. Even for a given setting, experimentally determined coefficients vary widely. The choice of wind function strongly influences estimated water consumption (fig. 19).

Estimates of evaporation were based on the wind function of Brady and others (1969) for ponds, Webster and Sherman (1995) for lakes, and Gulliver and Stefan (1986) for rivers. The Brady and others (1969) wind function was developed for cooling ponds. The Anderson (1954), Harbeck (1964), and Ward (1980) wind functions are also derived from cooling ponds but are inappropriate for low wind speeds; Ward's

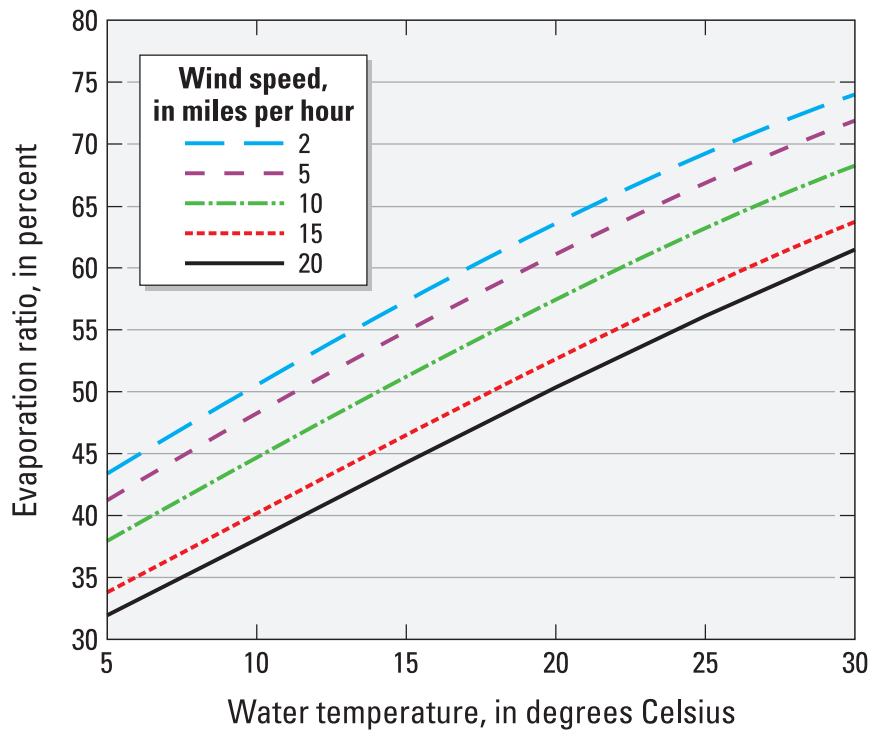

Figure 18. Evaporation ratio in relation to wind speed, estimated using Brady and others (1969) wind function. formula is equation 3 in Diehl (2011), expressed here in different units. The parameter values of Fulford and Sturm (1984) and Gulliver and Stefan (1986) were derived from flowing water. Webster and Sherman (1995) studied lakes without added heat. Other wind functions are discussed in McJannet and others (2012), Majewski and Miller (1979), and Edinger and others (1974).

The values of some wind functions, for example those of Anderson (1954), Harbeck (1964), and Ward (1980) go to zero at a wind speed of zero. In practice, convective vertical mixing takes place in the absence of wind due to density differences between the water-saturated air in the surface film over the warm cooling pond and the overlying air. Wind functions that reach zero were not used to estimate water consumption.

The Forced Evaporation from Water Surface (FEWS) spreadsheet (Appendix 4, available online in an Excel file at http://pubs.usgs.gov/sir/2013/5188/appendix/sir2013-5188 appendix4_fews_version_3.104.xlsx), implements the heat balance model to estimate forced evaporation from water surfaces driven by heat from thermoelectric plants. The user enters power plant identification numbers, elevations, pond or lake area for lake and pond cooling systems, and mean monthly values of condenser duty, water temperature, and wind speed. Because of the sensitivity of output to the wind function, and the unsettled status of the wind function in published literature, selection of the appropriate wind function is left to the user.

The FEWS spreadsheet includes wind functions derived for rivers and lakes and reviewed by McJannet and others (2012), and the wind function of Brady and others (1969) developed for dedicated cooling lakes. The parameter values of Fulford and Sturm (1984) and Gulliver and Stefan (1986) were derived from flowing water. Webster and Sherman (1995) studied lakes without added heat. Other wind functions

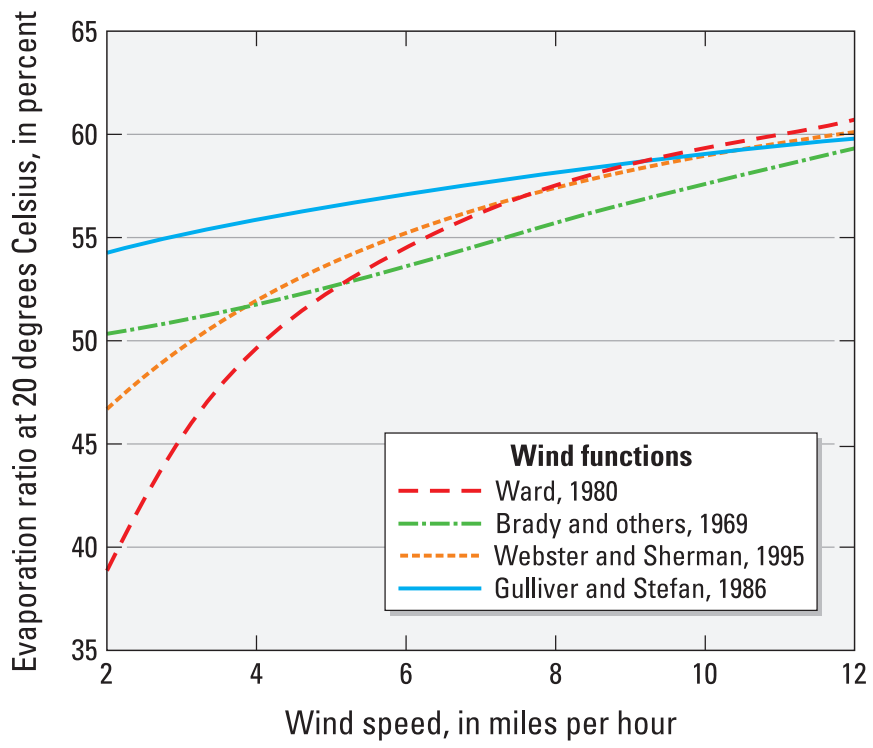

Figure 19. Evaporation ratio in relation to wind speed at 20 degrees Celsius for four selected wind functions. 
reviewed by McJannet and others (2012), Majewski and Miller (1979), and Edinger and others (1974) should be checked against the original publications before being used.

Natural water temperatures in the spreadsheet were derived from measured river temperature upstream from the plant, or in nearby lakes and streams, but in principle, a natural water temperature could be derived from air temperature and wet bulb temperature. The spreadsheet solves the relevant heat-loss equations iteratively to estimate a heated water temperature that matches the heat loading, and produces monthly and annual estimates of forced evaporation.

The method implemented in this spreadsheet has four major sources of uncertainty: natural water temperature, heat loading, wind function, and error intrinsic to the model. An error in the estimated natural water temperature of 1 produces a corresponding error in estimated heated water temperature, and an error of about 1 percent in evaporation ratio $(E R)$

(fig. 18). Error in estimated heat loading produces errors in the estimated $E R$ that are roughly proportional to heat loading; in cold water with a low heat loading, an error of $0.1 \mathrm{MW} /$ acre in heat loading produces an error in $E R$ of about 1 percent (fig. 20). The range in $E R$ between the largest and smallest wind function values ranges from about 3 percent for high wind speed to over 35 percent for wind speed of $1 \mathrm{mph}$; however, 90 percent of mean monthly wind speeds are greater than $4.5 \mathrm{mph}$, at which speed the range in estimated $E R$ is about 12 percent between the smallest and largest wind function values. Finally, the equations for heat balance give a calculated $E R$ within at most plus or minus 10 percent to 15 percent error from real heat loss (David I. Stannard, U.S. Geological Survey, written commun., 2012). Forced evaporation from dedicated cooling ponds can be measured using water budgets, and could be used to estimate the accuracy of the method.

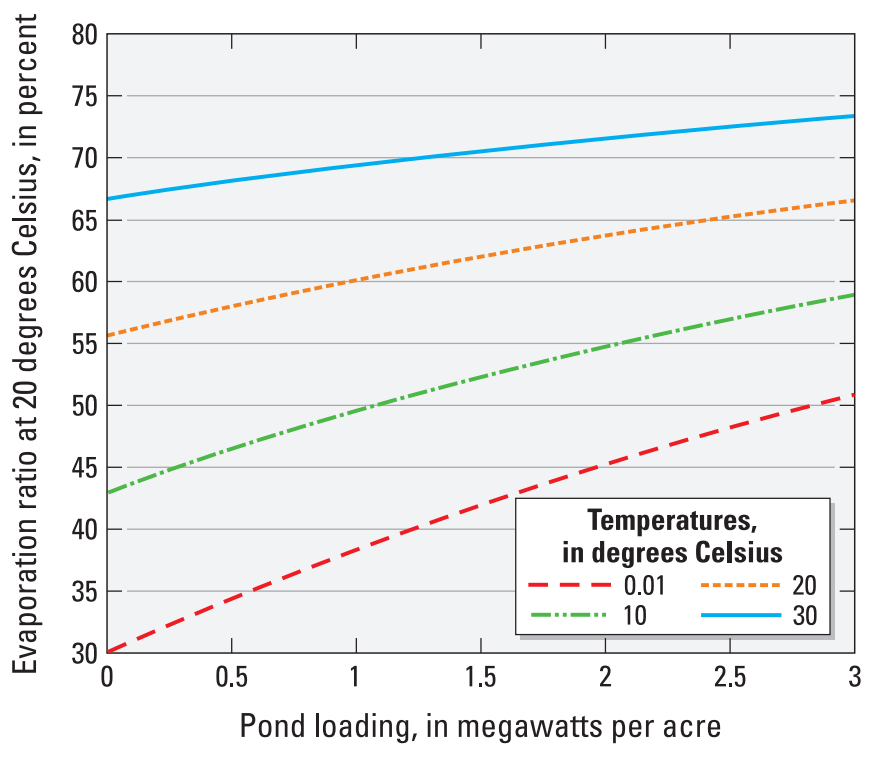

Figure 20. Effect of pond heat loading on evaporation ratio.

\section{Error Analysis and the Prediction of Maximum and Minimum Likely Consumption}

Error analysis took place in two stages-first calculating ranges of estimation error for condenser duty and evaporation ratio, and then combining these error terms by multiplication. Errors in parameter values such as boiler efficiency, auxiliary heat loss, and thermal efficiency, were assumed to be independent and normally distributed for the purposes of calculating an overall range of error. Many parameters were defined in the published literature as ranges or values of plus or minus some number. These ranges were assumed to represent the 95 percent of values within two standard deviations of a mean. Skewed distributions were ignored in analyzing error. Most parameter values were not defined by statistical analysis of measured values. Errors were not calculated for the two small generation-type categories of geothermal and solar thermoelectric. Water consumption for these generation types was estimated by simplified methods subject to undefined errors.

The maximum and minimum values of condenser duty were estimated to be the estimated value plus or minus 10 percent. For combustion steam units that reported a reasonable boiler efficiency, analysis of combined sources of error pointed to actual errors of 5 to 6 percent; 10 percent is considered to be conservative. For the 5 percent of combustion steam capacity with estimated boiler efficiency, the actual error is 7 percent to 10 percent.

Nuclear plants, despite the error introduced by estimating thermal efficiency, have low estimated error in condenser duty relative to other generation types. Calculated error is plus or minus 5 percent, but when error in estimated thermal efficiency is large, error in estimated condenser duty could approach 10 percent.

For combined-cycle plants, the critical assumption that heat loss in the exhaust gas is 20 percent is subject to an unknown degree of error. If the true range is 17 percent to 23 percent, then the error in condenser duty is close to 10 percent. If the stack losses are actually 15 percent to 25 percent, the error in condenser duty could be 15 percent or higher. This is another parameter for which errors seem likely to be greater in one direction than in the other. Since large, new plants have 20-percent stack loss, lower values for smaller and older combined-cycle plants seem unlikely, whereas higher values of stack losses are entirely plausible.

Despite the differences in calculated errors, the value of plus or minus 10 percent was chosen for the sake of simplicity in order to present a single value of uncertainty that captures typical conditions rather than produce tailored estimates for each situation. The level of uncertainty in the uncertainty analysis itself weighs against false precision in selecting a reasonable range.

The error in tower evaporation ratio was assumed to be 15 percent in addition to the full range of modeled values for the suite of 34 sets of tower-variable values. Thus, the maximum consumption was the maximum of the suite of towers plus 15 percent, and the minimum consumption was 
the minimum of the suite of towers minus 15 percent. When the equation of Rutberg and others (2011) yielded a higher $E R$ than the maximum calculated from the suite of towers, it was substituted as the maximum $E R$ value.

For evaporation ratio from water surfaces, an error of 18 percent was selected. The intrinsic error in the method of 15 percent is increased only slightly by input data uncertainty. The 18-percent error range is conservative for most plants, except for those with once-through cooling systems on the Great Lakes, where added uncertainty in the natural temperature might make plus or minus 21 percent a more appropriate value.

Multiplication of the estimated condenser duty and the estimated $E R$, including errors, resulted in a range in predicted water consumption of plus or minus 22 percent from the best estimate at plants with surface-water cooling. At plants with towers, the range in predicted water consumption is the range of results from the suite of towers plus or minus 18 percent.

\section{Other Types of Water Consumption}

Several modes of water consumption at thermoelectric plants were not amenable to modeling with heat and water budgets. These include evaporation from wet cooling towers at solar-thermal plants, flue-gas desulfurization at combustionsteam plants, and inlet cooling and nitrogen-oxides (NOx) control at combined-cycle plants.

\section{Solar-Thermal Generation}

Solar thermoelectric plants were not modeled with heat and water budgets because sufficient data are not available. Their fuel heat and generation are reported by fuel type at the plant level. However, the EIA-reported total heat use is nominal, based on an assumed 35-percent thermal efficiency, and no data on the amount of heat entering the steam turbine are available.

Parabolic-trough solar plants appear to consume 900 to 1,000 gallons per megawatt hour of net electric generation (gal/MWhe), given that wash water and cooling-tower blowdown are evaporated (Cohen and others, 1999; Kelly, 2006). Solar-power towers have consumption comparable to (Dahle, 2008) or substantially less than (U.S. Department of Energy, 2009) parabolic-trough plants. All solar thermoelectric plants in the study set had wet cooling towers, like the example plants in the studies cited.

An arbitrary consumption coefficient of $900 \mathrm{gal} / \mathrm{MWhe}$ was assigned to all solar thermoelectric plants. Solar thermoelectric plants are even smaller than geothermal plants and there are fewer of them, so use of this estimation method has little effect on regionally aggregated water consumption. Estimated water consumption at solar-thermal plants was about 0.05 percent of total thermoelectric water consumption.

\section{Flue-Gas Desulfurization}

Flue-gas desulfurization at coal- and waste-burning plants consumes water by incorporating the water into sulfurbearing minerals and by contributing water vapor to the stack gases. Based on average differences between water consumption rates with no FGD, dry FGD, and wet FGD presented in Appendix D of U.S. Department of Energy, National Energy Technology Laboratory (2010), FGD water consumption was estimated as $64 \mathrm{gal} / \mathrm{MWhe}$ for wet FGD and $40 \mathrm{gal} / \mathrm{MWhe}$ for dry FGD. For boilers burning some fuel that does not contain sulfur (for example, natural gas), the consumption was multiplied by the ratio of heat from sulfurous fuels to total fuel heat. The water consumed by FGD was about 5 percent of total thermoelectric water consumption.

\section{Minor Water Consumption at Combined-Cycle Plants}

Minor types of water consumption at combined-cycle plants include inlet cooling and NOx control in the combustion turbine part of the plant (Texas Water Development Board, 2003; Maulbetsch and DiFilippo, 2006). Inlet cooling can consume about $20 \mathrm{gal} / \mathrm{MWhe}$ and NOx reduction can consume about $50 \mathrm{gal} / \mathrm{MWhe}$. No publicly available data indicate whether either of these types of consumption takes place at each combustion turbine. Exclusion of these types of consumption introduces an unknown downward bias into water consumption estimates at some combined-cycle plants. Also, some combustion turbines that are not part of combined-cycle plants consume water, perhaps as much as $100 \mathrm{gal} / \mathrm{MWhe}$ (California Energy Commission, 2005), but are not included in the study set for this report.

\section{Conclusions}

The use of heat and water budgets to estimate water consumption at individual thermoelectric plants provides a useful check on other estimation approaches, and in many cases may be the most accurate method available. Constraining estimated evaporation at thermoelectric plants based on thermodynamics improves estimates of water consumption at plants where direct measurements of water use are absent or unreliable. Budgets based on heat and electric data provide an independent validation of consumption where it is measured. On a regional or national scale, budget-based consumption estimates could be used to guide policy discussions. For example, these estimates respond realistically to environmental change, increasing with temperature and wind speed.

Estimates of condenser duty vary in precision depending on what data are reported, and in what form, by the various types of thermoelectric plants. These estimates could be improved by more detailed reporting of boiler efficiency and fuel or heat use at some types of plants and could be 
superseded by accurately monitoring and reporting condenser duty. Nearly all fossil-fuel generation types are required to report fuel and generation data sufficient to calculate a heat budget; nuclear plant heat budgets can be constructed despite the lack of reported reactor heat data, based on maximum permitted reactor power. Geothermal and solar-thermal plants do not report enough data for a heat budget. Budgets could be improved by reporting fuel use by boiler and turbine and electricity by generator for combined-cycle plants. The quality of reported data is uneven, and quality control requires substantial effort. Some plants present ambiguities that have to be resolved by professional judgment. Additional information could be gathered at power plants that would eliminate the need for estimating condenser duty and tower evaporation with heat budgets, but not all of these data are required by plant operators.

Budget models of the evaporation process are more complex and less definitive than those that estimate condenser duty. The Leung and Moore method gives plausible estimates of the evaporation ratio for cooling towers, using available data. However, it is not definitive, and could be superseded by a better model, or, preferably, better monitoring and reporting of the elements of the water budget for cooling towers. In contrast, monitoring of evaporation from water surfaces is difficult at best, and cannot supersede modeling of the evaporation ratio for forced evaporation from water surfaces. The heat balance method presented in this report is not definitive, but it incorporates the main variables to which the evaporation ratio responds, and its output is realistically sensitive to them. This method would benefit from the development of better wind functions, and its precision would be improved by more reliable measurements of environmental variables at power plants.

\section{Acknowledgments}

The authors thank David I. Stannard of the USGS for his input on the surface-water evaporation model. The authors would also like to thank Andrew E. LaMotte and Andrew J. Sekellick of the USGS for their work on power plant locations and elevations.

\section{Selected References}

Anderson, E.R., 1954, Water-loss investigations-Lake Hefner studies, technical report: U.S. Geological Survey Professional Paper 269, $158 \mathrm{p}$.

Ashwood, A., and Bharathan, D., 2011, Hybrid cooling systems for low-temperature geothermal power production: Denver, Colorado, National Renewable Energy Laboratory, NREL/TP-5500-48765, $62 \mathrm{p}$.
Brady, D.K., Graves, W.L., and Geyer, J.C., 1969, Surface heat exchange at power plant cooling lakes, report 5: Baltimore, Maryland, The Johns Hopkins University Department of Geography and Engineering, 154 p.

Breiman, L., and Spector, P., 1992, Submodel selection and evaluation in regression: the $\mathrm{x}$-random case: International Statistical Review, v. 60, no. 3, p. 291-319.

California Energy Commission, 2005, A preliminary environmental profile of California's imported electricity: Energy Commission staff report prepared in support of the 2005 Integrated energy policy report, $71 \mathrm{p}$., accessed April 23, 2013 at $h t t p: / / w w w . e n e r g y . c a . g o v / 2005$ publications/CEC700-2005-017/CEC-700-2005-017.PDF.

Cheremisinoff, N.P., and Cheremisinoff, P.N., 1981, Cooling towers selection, design and practice: Ann Arbor, Michigan, Ann Arbor Science Publishers, 347 p.

Clark, C.E., Harto, C.B., Sullivan, J.L., and Wang, M.Q., 2010, Water use in the development and operation of geothermal power plants: Argonne, Illinois, Argonne National Laboratory, ANL/EVS/R-10/5, 74 p.

Cohen G.E., Kearney, D.W., and Kolb, G.J., 1999, Final report on the operation and maintenance improvement program for concentrating solar power plants: Albuquerque, New Mexico, Sandia National Laboratories (SNL), and Livermore, California, Lawrence Livermore National Laboratory, No. SAND99-1290, 186 p.

Cooling Technology Institute, 2010, Recommendations for winter operations of water cooling towers, chap. 4 of Cooling Tower Manual: Houston, Texas, Cooling Technology Institute, $16 \mathrm{p}$.

Dagdas, A., Erdem, H.H., and Sevilgen, S.H., 2005, Performance analysis of gas turbine integrated geothermal power plant in Turkey - the proposed Kizildere project: Antalya, Turkey, Proceedings, World Geothermal Congress, 2005, p. 1-5.

Dahle, D. Sr., 2008, Solar Technology BLM-Arizona Lands Training (June 25, 2008), accessed February 16, 2013 at http://www.blm.gov/pgdata/etc/medialib/ blm/wo/MINERALS_REALTY_AND_RESOURCE PROTECTION_lenergy/renewable_references.Par.63109. File.dat/Solar percent20Energy - AZ percent20Lands percent20Training percent2006.25.08.pdf.

Dennen, B., Larson, D., Lee, C., Lee, J., and Tellinghuisen, S., 2007, California's energy-water nexus - water use in electricity generation: Santa Barbara, California, University of California, Bren School of Environmental Management and Science, $194 \mathrm{p}$. 
Diehl, T.H., 2011, Estimating forced evaporation from surface water, in Proceedings of the Third Thermal Ecology and Regulation Workshop, October 11-12, 2011, Maple Grove, Minnesota: Palo Alto, California, Electrical Power Research Institute, p. 23-1-23-10.

DiPippo, Ronald, 2004, Second law assessment of binary plants generating power from low-temperature geothermal fluids: Geothermics, v. 33, no. 5, p. 565-586, accessed July 28, 2013 at http://www.sciencedirect.com/science/article/ pii/S0375650504000094.

Drader, D., Jonsson, M.T., and Palsson, H., 2012, Improved power production efficiency of hydrothermal reservoirs using downhole pumps, in Proceedings of the ThirtySeventh Workshop on Geothermal Reservoir Engineering, January 30-February 1, 2012, Stanford, California: Stanford, California, Stanford University, SGP-TR-194, accessed April 23, 2013 at http://www.geothermal-energy. org/pdf/IGAstandard/SGW/2012/Drader.pdf.

Dziegielewski, Ben, and Kiefer, J.C., 2010, Water conservation measurement metrics-guidance report: American Water Works Association Water Conservation Division Subcommittee Report, submitted to The American Water Works Association Water Conservation Division Subcommittee: Denver, Colorado, 62 p., accessed July 28, 2013 at http://www.awwa.org/Portals/0/files/resources/ resource\%20dev\%20groups/tech\%20and\%20educ\%20 program/documents/WaterConservationMeasurementMetric sGuidanceReport.pdf.

Eaton, Joe, 2012, Record heat, drought pose problems for U.S. electric power: National Geographic News, accessed April 25, 2013 at http://news.nationalgeographic.com/ news/energy/2012/08/120817-record-heat-drought-poseproblems-for-electric-power-grid/.

Edinger, J.E., Brady, D.K., and Geyer, J.C., 1974, Heat exchange and transport in the environment: Baltimore, Maryland, The Johns Hopkins University, Department of Geography and Environmental Engineering, Report No. 14 (No. NP-2900127), 137 p.

Electric Power Research Institute (EPRI), 2011, Program on technology innovation: Electricity use in the electric sector: Opportunites to enhance electric energy efficiency in the production and delivery of electricity, 2011 Technical Report: Palo Alto, California, EPRI, Final Report 1024651, accessed February 11, 2013 at http://www.pserc.wisc.edu/ documents/publications/special_interest_publications/ EPRI_Electricity_Use_Report_Final_1024651.pdf.

Esri, 2012, ArcGIS: Release 10.1: Redlands, California, Environmental Systems Research Institute.
Evapco, 2010, Cooling Towers_-Free Cooling Operation. Evapco Engineering bulletin EB23D, April 16, 2010, 28 p., Taneytown, Maryland, accessed August 20, 2013 at http:// www.evapco.eu/sites/evapco.eu/files/white_papers/23-FreeCooling-for-Cooling-Towers.pdf.

Franco, Alessandro, and Villani, Marco, 2009, Optimal design of binary cycle power plants for water-dominated, medium-temperature geothermal fields: Geothermics, v. 38, no. 4, p. 379-391, http://dx.doi.org/10.1016/j. geothermics.2009.08.001, accessed July 28, 2013 at http://www.sciencedirect.com/science/article/pii/ S0375650509000480.

Fulford, J.M., and Sturm, T.W., 1984, Evaporation from flowing channels: Journal of Energy Engineering, ASCE, v. 110, no. 1, p. $1-10$.

Golub, Miroslav, Kurevija, Tomislav, and Pravica, Zdravko, 2006, Maximum energy output of geopressured geothermal reservoirs in Croatia, in Frankovic, Bernard, ed., Rijeka: Hrvatski savez za energiju, 2006 International Congress Energy and Environment October 25-27, 2006, v. 2, p. 121-130, accessed August 20, 2013 at http://bib.irb.hr/ datoteka/264772.MAXIMUM_ENERGY_OUTPUT_OF_ GEOPRESSURED_GEOTHERMAL_RESERVOIRS_IN_ CROATIA.pdf.

Gulliver, J.S., and Stefan, H.G., 1986, Wind function for a sheltered stream: Journal of Environmental Engineering, v. 112 , no. 2, p. 387-399.

Harbeck, G.E., Jr., 1964, Estimating forced evaporation from cooling ponds: Journal of the Power Division, ASCE, v. 90, no. 3 , p. 1-10.

Hu, M.C., Pavlenco, G.F., and Englesson, G.A., 1978, Water consumption and costs for various steam electric power plant cooling systems: Research Triangle Park, North Carolina, U.S. Environmental Protection Agency, Industrial Environmental Research Laboratory, EPA-600/7-78-157, $129 \mathrm{p}$.

Hu, M.C., Pavlenco, G.F., and Englesson, G.A., 1981, Executive summary for power plant cooling system water consumption and nonwater impact reports: Research Triangle Park, North Carolina, U.S. Environmental Protection Agency, Industrial Environmental Research Laboratory, EPA-600/S7-81-112, 19 p.

Huston, R.J., 1975, An overview of water requirements for electric power generation, in Gloyna, E.F., Herbert, H.W., and Howard, R.D., eds., Water management by the electric power industry: Austin, Texas, University of Texas at Austin, Center for Research in Water Resources, p. 39-49. 
Hutson, S.S., Barber, N.L., Kenny, J.F., Linsey, K.S., Lumia, D.S., and Maupin, M.A., 2004, Estimated use of water in the United States in 2000: U.S. Geological Survey Circular 1268, 46 p. (also available online at http://pubs.usgs.gov/ circ/2004/circ1268/).

Hutson, S.S., comp., 2007, Guidelines for preparation of state water-use estimates for 2005: U.S. Geological Survey Techniques and Methods Book 4, Chap. E1, 36 p. (also available online at http://pubs.usgs.gov/tm/2007/tm4e1/).

International Atomic Energy Agency, 2009, Nuclear technology review 2009, 133 p., International Atomic Energy Agency, Vienna, accessed August 20, 2013 at http://www. iaea.org/Publications/Reports/ntr2009.pdf.

International Energy Agency, 2008, Combined heat and power-Evaluating the benefits of greater global investment, OECD/IEA, Paris, accessed February 27, 2013 at http://www.iea.org/publications/freepublications/ publication/chp_report.pdf.

Kagel, A., Bates, D., and Gawell, K., 2005, A guide to geothermal energy and the environment: Washington, D.C., Geothermal Energy Association, 75 p.

Kelly, B., 2006, Nexant parabolic trough solar power plant systems analysis - Task 2-comparison of wet and dry Rankine cycle heat rejection: Denver, Colorado, National Renewable Energy Laboratory, NREL/SR-550-40163, 28 p.

Kenny, J.F., Barber, N.L., Hutson, S.S., Linsey, K.S., Lovelace, J.K., and Maupin, M.A., 2009, Estimated use of water in the United States in 2005: U.S. Geological Survey Circular 1344, 52 p. (also available online at http://pubs. usgs.gov/circ/1344/).

Krivoruchko, Konstantin, 2012, Empirical bayesian kriging: ArcUser, v. 15, no. 4, p. 6-10.

Larson, D., Lee, C., Tellinghuisen, S., and Keller, A., 2007, California's energy-water nexus: Water use in electricity generation: Southwest Hydrology, v. 6, no. 5, p. 20-22.

Leung, Paul and Moore, R.E., 1970, Water consumptive determination for steam power plant cooling towers: a heat and mass balance method: Combustion, v. 42, no. 5, p. 14-23.

Leung, Paul and Moore, R.E, 1971, Water consumption study for Navajo plant: Journal of the Power Division, v. 97, no. 4, p. 749-766.

McJannet, D.L., Webster, I.T., and Cook, F.J., 2012, An areadependent wind function for estimating open water evaporation using land-based meteorological data: Environmental Modelling \& Software, v. 31, p. 76-83, http://dx.doi. org/10.1016/j.envsoft.2011.11.017, accessed July 30, 2013 at http://www.sciencedirect.com/science/article/pii/ S1364815211002805.
MacKichan, K.A., 1951, Estimated water use in the United States, 1950: U.S. Geological Survey Circular 115, 13 p. (available online only at http://pubs.er.usgs.gov/publication/ cir115).

MacKichan, K.A., 1957, Estimated water use in the United States, 1955: U.S. Geological Survey Circular 398, 18 p. (available online only at http://pubs.er.usgs.gov/publication/ cir398).

MacKichan, K.A., and Kammerer, J.C., 1961, Estimated use of water in the United States, 1960: U.S. Geological Survey Circular 456, 44 p. (available online only at http://pubs. er.usgs.gov/publication/cir456).

Macknick, J., Newmark, R., Heath, G., and Hallett, K.C., 2011, A review of operational water consumption and withdrawal factors in electricity generating technologies: Golden, Colorado, National Renewable Energy Laboratory Technical report NREL/TP_6A20-50900, 21 p., accessed August 19, 2013 at http://www.nrel.gov/docs/ fy11osti/50900.pdf.

Majewski, W., and Miller, D.C., 1979, Predicting effects of power plant once-through cooling on aquatic systems: A state-of-the-art report of IHP Working Group 6.2 on the effects of thermal discharges: Paris, France, UNESCO, Technical papers in hydrology 20, $171 \mathrm{p}$.

Marley, 2012, Operating cooling towers in freezing weather: Bellevue, Washington, Olympic Engineered Sales, Inc., Marley technical report H-003B, 8 p. accessed August 20, 2013 at http://olyengsales.com/techreports.html.

Maulbetsch, J.S., and DiFilippo, M.N., 2006, Cost and value of water use at combined-cycle power plants: Prepared for California Energy Commission, Public Interest Energy Research Program, PIER Energy-Related Environmental Research, CEC-500-2006-034, [variously paged], accessed July 30, 2013 at http://www.energy. ca.gov/2006publications/CEC-500-2006-034/CEC-5002006-034.PDF.

Mishra, G.S., Glassley, W.E., and Yeh, Sonia, 2011, Realizing the geothermal electricity potential — water use and consequences: Environmental Research Letters, v. 6, no. 3, 8 p., accessed July 30, 2013 at http://dx.doi. org/10.1088/1748-9326/6/3/034023.

Murray, C.R., 1968, Estimated use of water in the United States, 1965: U.S. Geological Survey Circular 556, 53 p. (available online only at http://pubs.er.usgs.gov/publication/ cir556).

Murray, C.R., and Reeves, E.B., 1972, Estimated use of water in the United States, 1970: U.S. Geological Survey Circular 676, 37 p. (available online only at http://pubs.er.usgs.gov/ publication/cir676). 
Murray, C.R., and Reeves, E.B., 1977, Estimated use of water in the United States, 1975: U.S. Geological Survey Circular 765, 39 p. (available online only at http://pubs.er.usgs.gov/ publication/cir765).

Pilz, J., and Spöck, G., 2007, Why do we need and how should we implement Bayesian kriging methods: Stochastic Environmental Research and Risk Assessment, v. 22, no. 5, p. 621-632.

Rutberg M., Delgado, A., Herzog, H., and Ghoniem, A., 2011, A system-level generic model of water use at power plants and its application to regional water use estimation, in Proceedings of the American Society of Mechanical Engineers, 2011 International Mechanical Engineering Congress and Exposition, Denver, Colorado, 11 p.

Sathyanathan, V.T., 2010, Running a coal fired boiler at the best efficiency: Bright Hub Engineering, accessed March 25, 2013 at http://www.brighthubengineering.com/powerplants/41375-running-a-coal-fired-boiler-at-the-bestefficiency/.

Solley, W.B., Chase, E.B., and Mann, W.B., IV, 1983, Estimated use of water in the United States in 1980: U.S. Geological Survey Circular 1001, 55 p. (available online only at http://pubs.er.usgs.gov/publication/cir1001).

Solley, W.B., Merk, C.F., and Pierce, R.R., 1988, Estimated use of water in the United States in 1985: U.S. Geological Survey Circular 1004, 82 p. (available online only at http:// pubs.er.usgs.gov/publication/cir1004).

Solley, W.B., Pierce, R.R., and Perlman, H.A., 1998, Estimated use of water in the United States in 1995: U.S. Geological Survey Circular 1200, 71 p. (available online only at http://pubs.er.usgs.gov/publication/cir1200).

Stannard, D.I., Rosenberry, D.O., Winter, T.C., and Parkhurst, R.S., 2004, Estimates of fetch-induced errors in Bowenratio energy-budget measurements of evapotranspiration from a prairie wetland, Cottonwood Lake area, North Dakota, USA: Wetlands, v. 24, no. 3, p. 498-513, accessed July 30, 2013 at http://link.springer.com/ article/10.1672\%2F0277-5212(2004)024\%5B0498\%3AEO FEIB\%5D2.0.CO\%3B2\#.

Strauss, J.B., 1978, Comparison of model predictions and consumptive water use of closed cycle cooling system, Final Report, March-July 1978: Springfield, Virginia, Versar, Inc., EPA-600/7-78-206, [variously paged].

Stultz, S.C., and Kitto, J.B., eds., 1992, Steam, its generation and use (40th ed.): Barberton, Ohio, Babcock \& Wilcox, $131 \mathrm{p}$.
Templin, W.E., Herbert, R.A., Stainaker, C.B., Horn, Marilee, and Solley, W.B., 1999, National handbook of recommended methods for water data acquisition-Chapter $11 \mathrm{~J}$ - Thermoelectric power generation: U.S. Geological Survey, accessed August 22, 2013, at http://pubs.usgs.gov/ chapter11/chapter11J.html.

Texas Water Development Board, 2003, Power generation water use in Texas for the years 2000 to 2060: Final Report: Austin, Texas, 141 p. plus appendixes.

The Cooling Tower Company, L.C., 2005, Installation, operation and maintenance manual for Series TCI cooling tower: TCI Cooling, Tower Revision 1, 35 p.

United Nations Environment Programme, Division of Technology, 2006, Energy efficiency guide for industry in Asia: United Nations Publications, 17 p., accessed March 25, 2013 at http://www.energyefficiencyasia.org/docs/ ee_modules/Chapter-Cooling\%20Towers.pdf.

U.S. Census Bureau, North American Industry Classification System, 2007, accessed August 20, 2013 at http://www. census.gov/cgi-bin/sssd/naics/naicsrch? chart=2007.

U.S. Department of Energy, 2009, Concentrating solar power commercial application study: Reducing water consumption of concentrating solar power electricity generation: Report to Congress: Washington, D.C., U.S. Department of Energy, $24 \mathrm{p}$.

U.S. Department of Energy, Energy Information Administration, 2001, 2000 Form EIA-860 database, accessed August 20, 2013 at http://www.eia.gov/electricity/ data/eia860/index.html.

U.S. Department of Energy, Energy Information Administration, 2009, 2008 Form EIA-860 database, accessed January 22, 2013 at http://www.eia.gov/electricity/ data/eia860/index.html.

U.S. Department of Energy, Energy Information Administration, 2011a, 2010 Form EIA-860 database, Annual electric generator report, accessed January 22, 2013 at http://www.eia.gov/electricity/data/eia860/index.html.

U.S. Department of Energy, Energy Information Administration, 2011b, 2010 Form EIA-923 database, Power plant operations report, accessed January 22, 2013 at http://www.eia.gov/electricity/data/eia923/.

U.S. Department of Energy, Energy Information Administration, 2013, Electric Power Annual 2011, accessed August 21, 2013 at http://www.eia.gov/electricity/ annual/pdflepa.pdf. 
U.S. Department of Energy, National Energy Technology Laboratory, May 1999, DOE/FE-0400 Market-based advanced coal power systems: Final Report, 374 p., accessed August 21, 2013 at http://www.netl.doe.gov/ technologies/coalpower/turbines/refshelf/igcc-h2-sygas/ marketbased_systems_report.pdf.

U.S. Department of Energy, National Energy Technology Laboratory, 2007a, Cost and performance baseline for fossil energy plants, DOE/NETL-2007/1281, Volume 1: Bituminous coal and natural gas to electricity final report, accessed February 11, 2013 at http://www.netl.doe.gov/ energy-analyses/pubs/BitBase_FinRep_2007.pdf.

U.S. Department of Energy, National Energy Technology Laboratory, 2007b, Coal power plant database, accessed August 20, 2013 at http://www.netl.doe.gov/energyanalyses/pubs/cppd/XLS\%20CPPDB\%202005\%20-\%20 Public.zip.

U.S Department of Energy, National Energy Technology Laboratory, September 30, 2010, Estimating freshwater needs to meet future thermoelectric generation requirements, 2010 update: U.S. Department of Energy, DOE/ NETL-400/2010/1339, 109 p., accessed August 20, 2013 at http://www.netl.doe.gov/energy-analyses/refshelf/ PubDetails.aspx? Action=View $\&$ PubId $=335$ (index page) or http://www.netl.doe.gov/energy-analyses/pubs/2010_Water_ Needs_Analysis.pdf(manuscript).

U.S. Environmental Protection Agency, 2006, National Electric Energy Data System (NEEDS) 2006, accessed March 27, 2013 at http://www.epa.gov/airmarkets/ progsregs/epa-ipm/BaseCase2006.html (index page), http://www.epa.gov/airmarkets/progsregs/epa-ipm/docs/ v410/NEEDSv410.zip (Excel spreadsheet database), and http://www.epa.gov/airmarkets/progsregs/epa-ipm/docs/ v410/Guide_to_NEEDSv410.pdf, and http://www.epa.gov/ airmarkets/progsregs/epa-ipm/docs/v410/Chapter4.pdf (supporting documentation).

U.S. Environmental Protection Agency, 2007a, Emissions \& Generation Resource Integrated Database (eGRID), accessed January 22, 2013 at http://www.epa.gov/ cleanenergy/energy-resources/egrid/index.html\#download.
U.S. Environmental Protection Agency, 2007b, National Hydrography Dataset Plus-NHDPlus, Version 1.1:

Washington D.C., U.S. Environmental Protection Agency, Office of Water (vector/raster digital data.)

U.S. Environmental Protection Agency, Enforcement \& Compliance History Online (ECHO), [n.d.], accessed January 22, 2013 at http://www.epa-echo.gov/echo.

U.S. Government Accountability Office, 2009, Energy-water nexus: Improvements to Federal water use data would increase understanding of trends in power plant water use: Report to the Chairman, Committee on Science and Technology, House of Representatives, GAO-10-23, 73 p., accessed July 31, 2013 at http://www.gao.gov/new.items/ d1023.pdf.

U.S. Nuclear Regulatory Commission, 2009, 2009-2010 Information Digest, NUREG-1350, 21, 194 p., accessed August 20, 2013 at http://www.nrc.gov/reading-rm/doccollections/nuregs/staff/sr1350/v21/sr1350v21.pdf.

U.S. Nuclear Regulatory Commission, 2010, 2010-2011 Information Digest, NUREG-1350, 22, 191 p., accessed August 21, 2013 at http://pbadupws.nrc.gov/docs/ML1024/ ML102460490.pdf.

U.S. Nuclear Regulatory Commission, 2011, 2011-2012 Information Digest, NUREG-1350, 23, 186 p., accessed August 21, 2013 at http://www.nrc.gov/reading-rm/doccollections/nuregs/staff/sr1350/v23/sr1350v23.pdf.

Ward, G.H., Jr., 1980, Accuracy of Harbeck diagram for forced evaporation: Journal of the Energy Division, v. 106, no. 1, p. 23-31.

Webster, I.T., and Sherman, B.S., 1995, Evaporation from fetch-limited water bodies: Irrigation Science, v. 16, p. 53-64. 


\section{Glossary}

\section{B}

boiler efficiency the ratio between the amount of heat used to generate steam and the total heat content of the fuel that is consumed.

\section{C}

combined heat and power generating systems that produce both heat and electricity from a single heat source and export waste heat to other heat-using processes.

condenser duty the amount of waste heat delivered to the cooling system through the condenser.

cooling system a system that removes waste heat from a power plant condenser and transfers it to the atmosphere.

cooling-system type the technology used to dissipate condenser duty to the atmosphere; in this report, wet cooling towers and surfacewater cooling are the types considered.

\section{D}

dry cooling system a cooling system that condenses steam and transfers the waste heat to the atmosphere without the consumption of water.

\section{E}

evaporation ratio the ratio of the amount of heat transferred to the air as evaporation to the condenser duty.

exported heat the waste heat produced in electricity generation that is used in other heat-using processes, such as for a heating system.

\section{$\mathbf{F}$}

forced evaporation the increase in evaporation of surface water due to the added heat of discharged cooling water.

freshwater water that contains less than 1,000 milligrams per liter $(\mathrm{mg} / \mathrm{L})$ of dissolved solids.

\section{G}

generating unit any combination of physically connected generators, reactors, boilers, combustion turbines, or other prime movers operated together to produce electric power.

generation type the type of technology used to generate electricity in a given unit or plant, including the energy source and prime mover.

H

heat budget a summation of all significant flows of heat into and out of a system such as a power plant.

heat loading an estimate of the ratio of condenser duty to the area over which heat is dissipated.

heat rate the number of British thermal units (Btu) of fuel it takes to produce one kilowatt hour $(\mathrm{kWh})$ of electricity.

L

linked heat and water budget a summation of all significant flows of heat and water into and out of a power plant, linked by converting energy flows embodied in water flow and evaporation into their equivalent volume flow rates of liquid water.

\section{0}

once-through cooling system a cooling system in which the water is withdrawn from a surface-water source other than a recirculating pond to condense the steam used to generate electricity and that discharges the water back to surface water at a higher temperature.

\section{P}

plant a facility that generates electricity from another source of energy such as fossil fuels, nuclear fission, geothermal energy, or solar radiation and heat.

prime mover in thermoelectric plants, the prime mover is the turbine that converts the energy in heated gases to mechanical energy. 
$\mathbf{R}$

recirculating cooling system a cooling system in which water is circulated through condensers, cooled, and then re-used in the same process.

\section{S}

surface-water cooling a cooling-system type that transfers heat from a condenser to the atmosphere through evaporation at the free surface of an open body of water. In addition to evaporation, some heat leaves the water surface through conduction and radiation.

\section{$\mathbf{T}$}

thermal efficiency the percentage of fuel heat used to produce electricity.

thermoelectric relating to the generation of electric power from heat. thermoelectric water consumption the water evaporated or incorporated into byproducts as a result of the production of electricity from heat.

thermoelectric water withdrawal the water removed from groundwater or surface water for use in a thermoelectric power plant.

W

waste heat heat used but not converted to electricity in a thermoelectric plant.

water budget a summation of all significant flows of water into and out of a system such as a power plant.

wet cooling tower a cooling-system type that transfers heat from a condenser to the atmosphere primarily through evaporation, and to a lesser extent through conduction, in a natural-draft or mechanical-draft tower. 


\section{Appendixes 1-3}


Appendix 1. The 1,284 thermoelectric plants one megawatt nameplate capacity or greater with water-cooling systems in the United States, 2010.

[EIA, U.S. Department of Energy, Energy Information Administration; MW, megawatt; initials associated with a power plant are part of the plant name, and not spelled out; --, nameplate capacity is not reported for the steam side of the combined-cycle power plant]

\begin{tabular}{|c|c|c|c|}
\hline County & $\begin{array}{c}\text { EIA } \\
\text { plant code }\end{array}$ & Plant name & $\begin{array}{c}\text { Nameplate capacity } \\
\text { (MW) }\end{array}$ \\
\hline \multicolumn{4}{|c|}{ Alabama (24 power plants) } \\
\hline Autauga & 7897 & E B Harris Electric Generating Plant & 564 \\
\hline Autauga & 55271 & Tenaska Lindsay Hill Generating Station & 390.1 \\
\hline Etowah & 7 & Gadsden & 138 \\
\hline Greene & 10 & Greene County & 568.4 \\
\hline Houston & 6001 & Joseph M Farley & $1,776.4$ \\
\hline Jackson & 50 & Widows Creek & $1,968.6$ \\
\hline Lowndes & 7698 & General Electric Plastic & 14.8 \\
\hline Mobile & 3 & Barry & $2,161.1$ \\
\hline Mobile & 7721 & Theodore Cogen Facility & 88.4 \\
\hline Mobile & 50407 & Mobile Energy Services LLC & 43.1 \\
\hline Mobile & 55241 & Hog Bayou Energy Center & 80 \\
\hline Morgan & 55292 & Decatur Energy Center & 171 \\
\hline Morgan & 55293 & Morgan Energy Center & 270 \\
\hline Shelby & 26 & E C Gaston & $2,012.8$ \\
\hline Tallapoosa & 55411 & Hillabee Energy Center & 306 \\
\hline Fairbanks North Star & 79 & Aurora Energy LLC Chena & 27.5 \\
\hline Fairbanks North Star & 6285 & North Pole & 13 \\
\hline Kenai Peninsula & 96 & Beluga & 62 \\
\hline \multicolumn{4}{|c|}{ Arizona (25 power plants) } \\
\hline Apache & 6177 & Coronado & 821.8 \\
\hline Apache & 8223 & Springerville & $1,749.6$ \\
\hline Cochise & 160 & Apache Station & 489.6 \\
\hline Coconino & 4941 & Navajo & $2,409.3$ \\
\hline Maricopa & 116 & Ocotillo & 227.2 \\
\hline Maricopa & 117 & West Phoenix & 641.6 \\
\hline Maricopa & 141 & Agua Fria & 390.4 \\
\hline Maricopa & 147 & Kyrene & 122 \\
\hline
\end{tabular}


Appendix 1. The 1,284 thermoelectric plants one megawatt nameplate capacity or greater with water-cooling systems in the United States, 2010.-Continued

[EIA, U.S. Department of Energy, Energy Information Administration; MW, megawatt; initials associated with a power plant are part of the plant name, and not spelled out; --, nameplate capacity is not reported for the steam side of the combined-cycle power plant]

\begin{tabular}{|c|c|c|c|}
\hline County & $\begin{array}{c}\text { EIA } \\
\text { plant code }\end{array}$ & Plant name & $\begin{array}{l}\text { Nameplate capacity } \\
\text { (MW) }\end{array}$ \\
\hline Maricopa & 6008 & Palo Verde & $4,209.3$ \\
\hline Maricopa & 8068 & Santan & 864.6 \\
\hline Maricopa & 55282 & Arlington Valley Energy Facility & 317 \\
\hline Maricopa & 55306 & Gila River Power Station & 1,084 \\
\hline Maricopa & 55372 & Harquahala Generating Project & 480 \\
\hline Maricopa & 55455 & Red Hawk & 408 \\
\hline Maricopa & 55481 & Mesquite Generating Station & 642 \\
\hline Maricopa & 57140 & Maricopa Solar & -- \\
\hline Mohave & 55124 & Griffith Energy LLC & 301.8 \\
\hline Mohave & 55177 & South Point Energy Center & 236 \\
\hline Navajo & 113 & Cholla & $1,128.8$ \\
\hline Navajo & 56616 & Snowflake White Mountain Power LLC & 27.2 \\
\hline Pima & 126 & H Wilson Sundt Generating Station & 504.5 \\
\hline Pinal & 118 & Saguaro & 250 \\
\hline Pinal & 55129 & Desert Basin & 272.1 \\
\hline Yuma & 120 & Yucca & 86.7 \\
\hline Yuma & 54694 & Yuma Cogeneration Associates & 18.5 \\
\hline \multicolumn{4}{|c|}{ Arkansas (16 power plants) } \\
\hline Benton & 6138 & Flint Creek & 558 \\
\hline Franklin & 201 & Thomas Fitzhugh & 59 \\
\hline Hot Spring & 170 & Lake Catherine & 552.5 \\
\hline Hot Spring & 55418 & KGen Hot Spring Generating Facility & 317 \\
\hline Hot Spring & 55714 & Hot Spring Power Project & 262 \\
\hline Independence & 6641 & Independence & 1,700 \\
\hline Jefferson & 6009 & White Bluff & 1,700 \\
\hline Jefferson & 55075 & Pine Bluff Energy Center & 56 \\
\hline Lafayette & 169 & Harvey Couch & 156.2 \\
\hline Mississippi & 55340 & Dell Power Station & 281 \\
\hline Mississippi & 56456 & Plum Point Energy Station & 720 \\
\hline Ouachita & 203 & McClellan & 136 \\
\hline Pope & 8055 & Arkansas Nuclear One & 1,845 \\
\hline Pulaski & 55221 & Harry L Oswald & 210 \\
\hline Union & 55380 & Union Power Partners LP & 1,020 \\
\hline Woodruff & 202 & Carl Bailey & 120 \\
\hline \multicolumn{4}{|c|}{ California (149 power plants) } \\
\hline Butte & 54469 & Pacific Oroville Power Inc & 18 \\
\hline Colusa & 50293 & Wadham Energy LP & 28.6 \\
\hline Contra Costa & 228 & Contra Costa & 718 \\
\hline Contra Costa & 271 & Pittsburg Power & $1,403.9$ \\
\hline Contra Costa & 10342 & Foster Wheeler Martinez & 33.5 \\
\hline
\end{tabular}


Appendix 1. The 1,284 thermoelectric plants one megawatt nameplate capacity or greater with water-cooling systems in the United States, 2010.-Continued

[EIA, U.S. Department of Energy, Energy Information Administration; MW, megawatt; initials associated with a power plant are part of the plant name, and not spelled out; --, nameplate capacity is not reported for the steam side of the combined-cycle power plant]

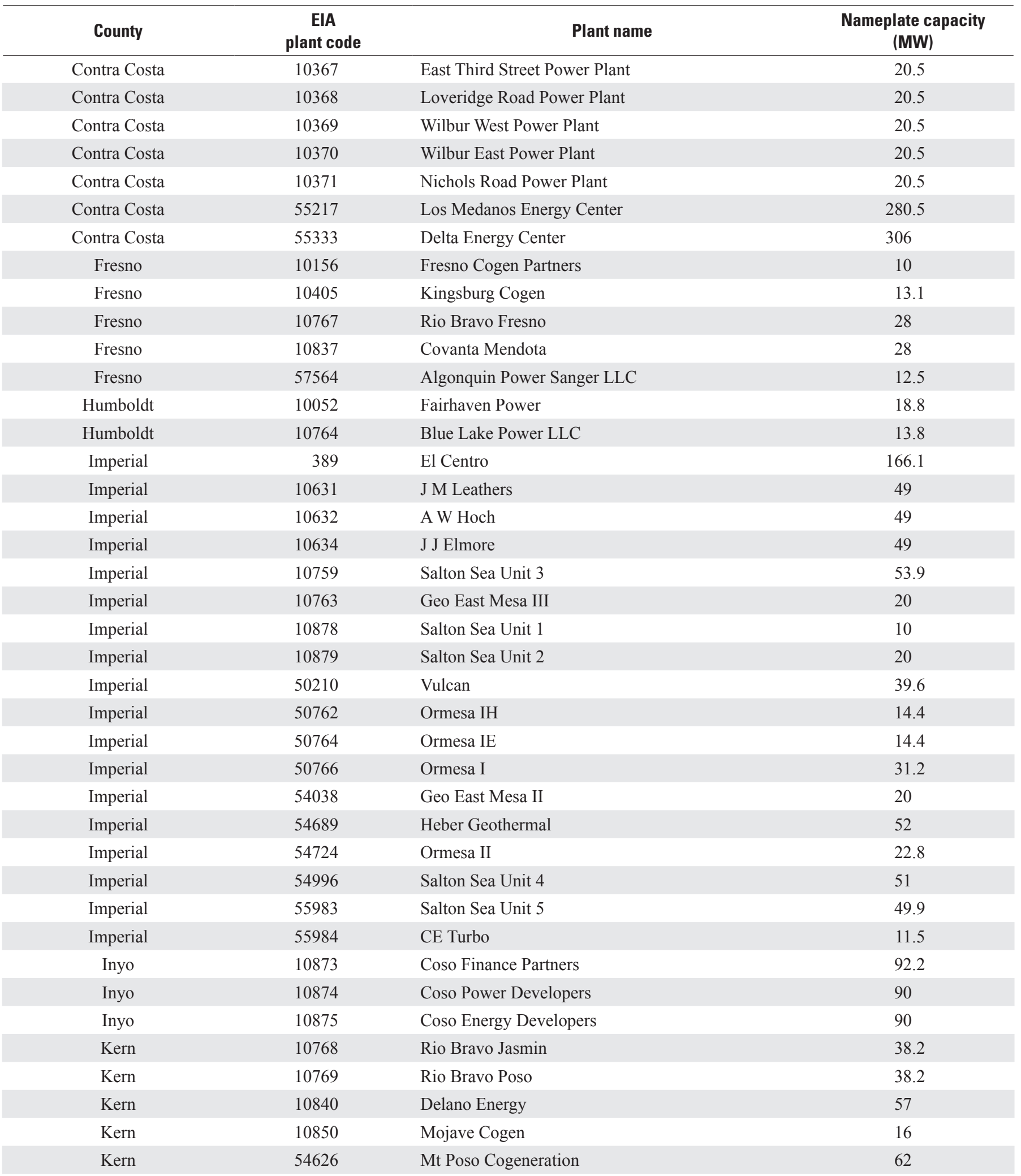


Appendix 1. The 1,284 thermoelectric plants one megawatt nameplate capacity or greater with water-cooling systems in the United States, 2010.-Continued

[EIA, U.S. Department of Energy, Energy Information Administration; MW, megawatt; initials associated with a power plant are part of the plant name, and not spelled out; --, nameplate capacity is not reported for the steam side of the combined-cycle power plant]

\begin{tabular}{|c|c|c|c|}
\hline County & $\begin{array}{c}\text { EIA } \\
\text { plant code }\end{array}$ & Plant name & $\begin{array}{c}\text { Nameplate capacity } \\
\text { (MW) }\end{array}$ \\
\hline Kern & 55151 & La Paloma Generating LLC & 1,200 \\
\hline Kern & 55182 & Sunrise Power LLC & 270 \\
\hline Kern & 55400 & Elk Hills Power LLC & 225 \\
\hline Kern & 55656 & Pastoria Energy Facility LLC & 275 \\
\hline Lake & 510 & Sonoma California Geothermal & 78 \\
\hline Lake & 902 & Bottle Rock Power & 55 \\
\hline Lake & 10199 & West Ford Flat Power Plant & 38 \\
\hline Lake & 10469 & Bear Canyon Power Plant & 24.4 \\
\hline Lassen & 54468 & Mt Lassen Power & 11.4 \\
\hline Los Angeles & 315 & AES Alamitos LLC & 1,922 \\
\hline Los Angeles & 330 & El Segundo Power & 684 \\
\hline Los Angeles & 356 & AES Redondo Beach LLC & $1,316.4$ \\
\hline Los Angeles & 377 & Grayson & 163 \\
\hline Los Angeles & 399 & Harbor & 67 \\
\hline Los Angeles & 400 & Haynes & $1,410.3$ \\
\hline Los Angeles & 404 & Scattergood & 823.2 \\
\hline Los Angeles & 408 & Valley & 311 \\
\hline Los Angeles & 10478 & Pitchess Cogen Station & 7.4 \\
\hline Los Angeles & 50541 & Harbor Cogen & 25.1 \\
\hline Los Angeles & 50837 & Southeast Resource Recovery & 35.6 \\
\hline Los Angeles & 50876 & Wheelabrator Norwalk Energy & 7.7 \\
\hline Los Angeles & 54015 & BKK Landfill & 6.8 \\
\hline Los Angeles & 56041 & Malburg & 58.8 \\
\hline Los Angeles & 56046 & Magnolia Power Project & 188.7 \\
\hline Los Angeles & 57323 & Sierra SunTower Solar Generating Station & 7.5 \\
\hline Madera & 56706 & Ampersand Chowchilla Biomass LLC & 12.5 \\
\hline Merced & 56707 & El Nido Facility & 12.5 \\
\hline Monterey & 260 & Dynegy Moss Landing Power Plant & $1,870.0$ \\
\hline Monterey & 10294 & King City Power Plant & 42.4 \\
\hline
\end{tabular}


Appendix 1. The 1,284 thermoelectric plants one megawatt nameplate capacity or greater with water-cooling systems in the United States, 2010.-Continued

[EIA, U.S. Department of Energy, Energy Information Administration; MW, megawatt; initials associated with a power plant are part of the plant name, and not spelled out; --, nameplate capacity is not reported for the steam side of the combined-cycle power plant]

\begin{tabular}{|c|c|c|c|}
\hline County & $\begin{array}{c}\text { EIA } \\
\text { plant code }\end{array}$ & Plant name & $\begin{array}{l}\text { Nameplate capacity } \\
\text { (MW) }\end{array}$ \\
\hline Orange & 335 & AES Huntington Beach LLC & 888 \\
\hline Placer & 10772 & Rio Bravo Rocklin & 27.9 \\
\hline Placer & 56298 & Roseville Energy Park & 80 \\
\hline Riverside & 56356 & Clearwater Power Plant & 8 \\
\hline Riverside & 57154 & Imperial Valley Resource Recovery & 18.1 \\
\hline Riverside County & 55853 & Inland Empire Energy Center & 819 \\
\hline Sacramento & 7527 & Carson Ice-Gen Project & 17.5 \\
\hline San Bernardino & 329 & Coolwater & 387.3 \\
\hline San Bernardino & 331 & Etiwanda Generating Station & 666 \\
\hline San Bernardino & 358 & Mountainview Power LLC & 428.9 \\
\hline San Bernardino & 10002 & ACE Cogeneration Facility & 108.0 \\
\hline San Bernardino & 10437 & SEGS I & 13.8 \\
\hline San Bernardino & 10438 & SEGS II & 30 \\
\hline San Bernardino & 10439 & SEGS III & 34.2 \\
\hline San Bernardino & 10440 & SEGS IV & 34.2 \\
\hline San Bernardino & 10441 & SEGS V & 34.2 \\
\hline San Bernardino & 55518 & High Desert Power Plant & 333 \\
\hline San Diego & 302 & Encina & 982 \\
\hline San Diego & 310 & Dynegy South Bay Power Plant & 272 \\
\hline San Diego & 360 & San Onofre Nuclear Generating Station & 2,254 \\
\hline San Diego & 10810 & NTC/MCRD Energy Facility & 2.6 \\
\hline San Diego & 10811 & Naval Station Energy Facility & 16.8 \\
\hline San Diego & 10812 & North Island Energy Facility & 4 \\
\hline San Diego & 54749 & Goal Line LP & 10.2 \\
\hline San Diego & 55985 & Palomar Energy & 229 \\
\hline San Diego & 57584 & University of California San Diego & 3 \\
\hline San Francisco & 273 & Potrero Power & 226 \\
\hline San Joaquin & 10502 & Thermal Energy Dev Partnshp LP & 23 \\
\hline San Joaquin & 10640 & Stockton Cogen & 60 \\
\hline
\end{tabular}


Appendix 1. The 1,284 thermoelectric plants one megawatt nameplate capacity or greater with water-cooling systems in the United States, 2010.-Continued

[EIA, U.S. Department of Energy, Energy Information Administration; MW, megawatt; initials associated with a power plant are part of the plant name, and not spelled out; --, nameplate capacity is not reported for the steam side of the combined-cycle power plant]

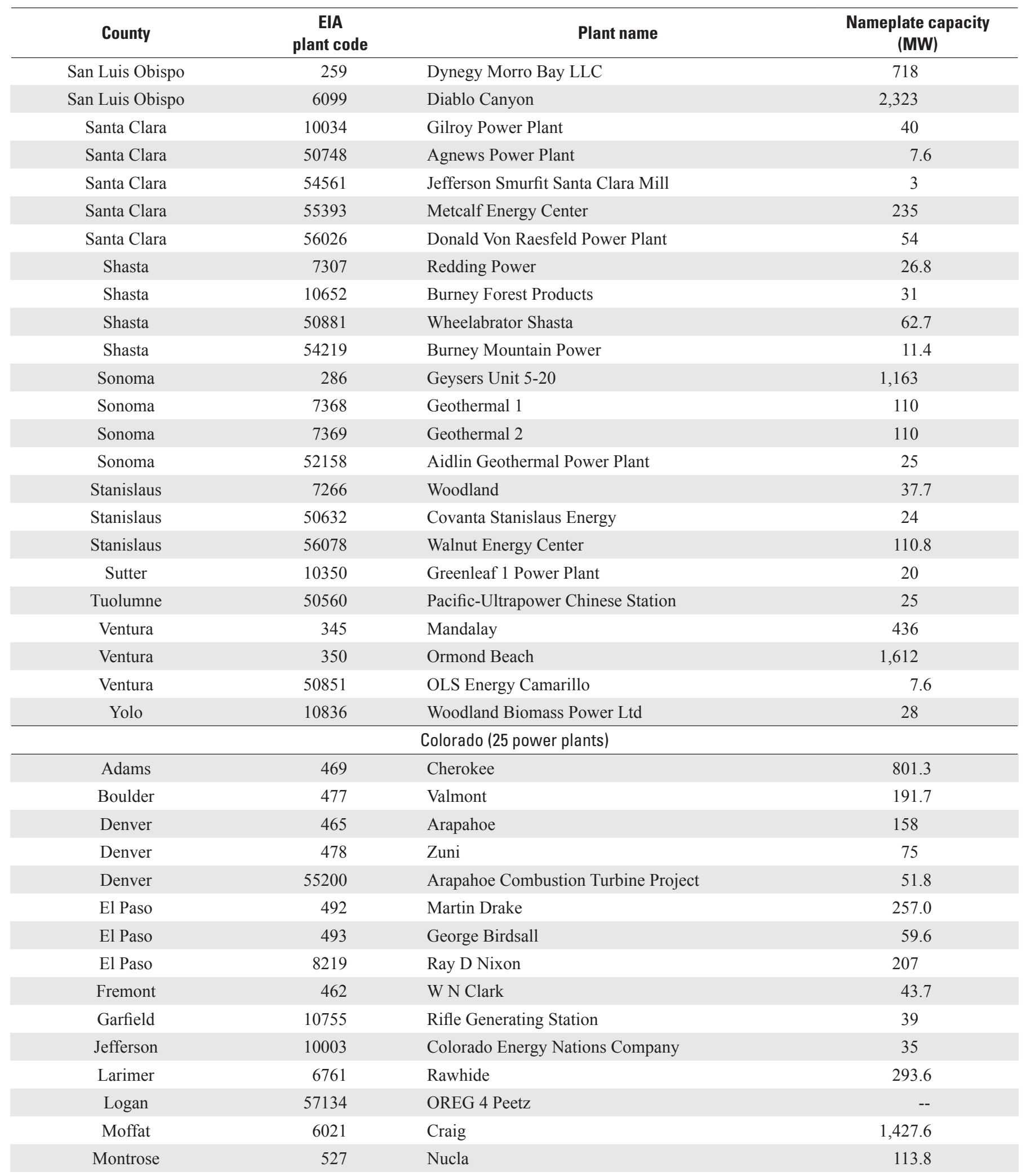


Appendix 1. The 1,284 thermoelectric plants one megawatt nameplate capacity or greater with water-cooling systems in the United States, 2010.-Continued

[EIA, U.S. Department of Energy, Energy Information Administration; MW, megawatt; initials associated with a power plant are part of the plant name, and not spelled out; --, nameplate capacity is not reported for the steam side of the combined-cycle power plant]

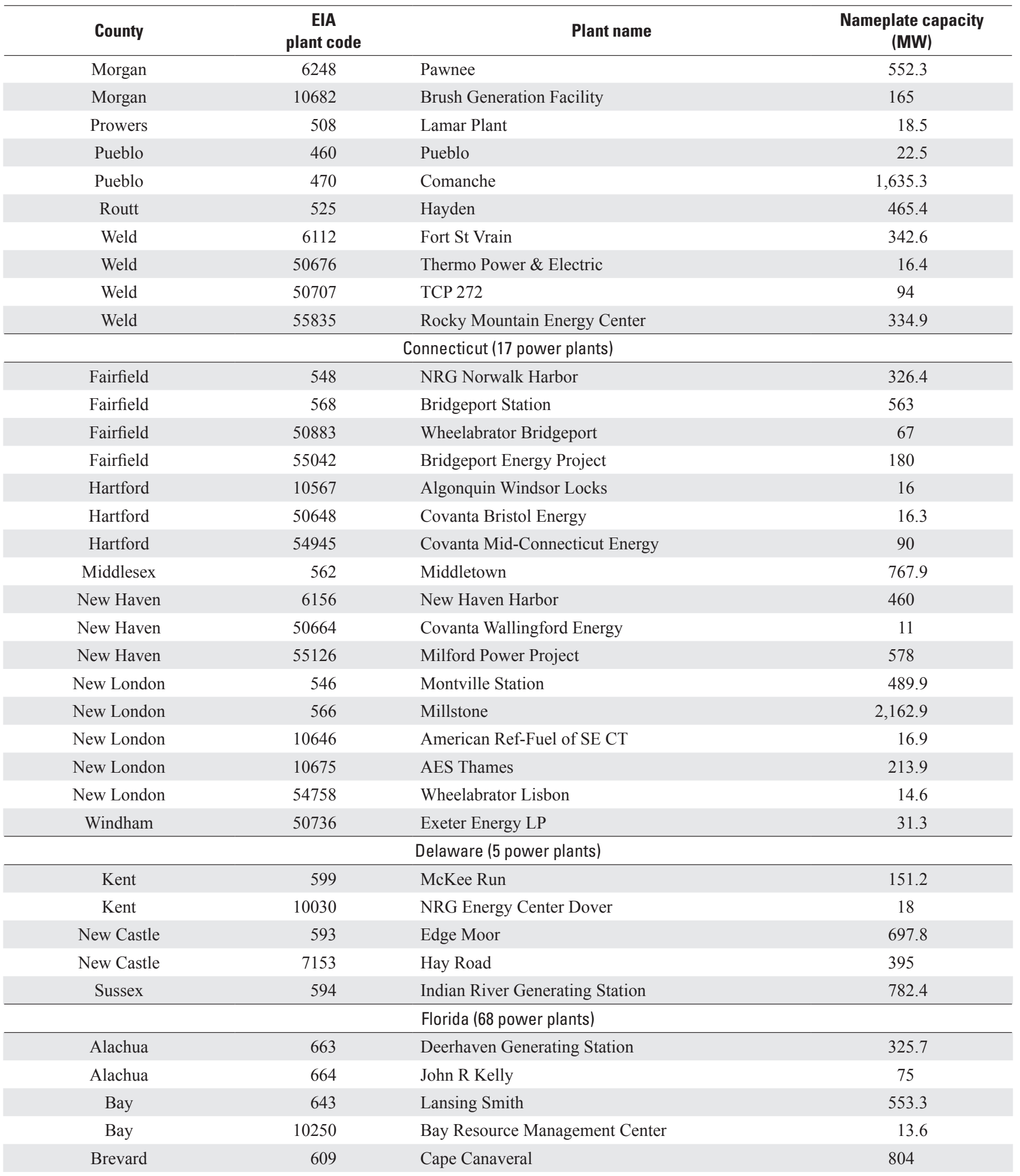


Appendix 1. The 1,284 thermoelectric plants one megawatt nameplate capacity or greater with water-cooling systems in the United States, 2010.-Continued

[EIA, U.S. Department of Energy, Energy Information Administration; MW, megawatt; initials associated with a power plant are part of the plant name, and not spelled out; --, nameplate capacity is not reported for the steam side of the combined-cycle power plant]

\begin{tabular}{|c|c|c|c|}
\hline County & $\begin{array}{c}\text { ElA } \\
\text { plant code }\end{array}$ & Plant name & $\begin{array}{c}\text { Nameplate capacity } \\
\text { (MW) }\end{array}$ \\
\hline Brevard & 55318 & Indian River & 609 \\
\hline Broward & 613 & Lauderdale & 302.4 \\
\hline Broward & 617 & Port Everglades & 1,300 \\
\hline Broward & 50572 & CSL Gas Recovery & 2.2 \\
\hline Broward & 54033 & Wheelabrator North Broward & 67.6 \\
\hline Citrus & 628 & Crystal River & $3,333.1$ \\
\hline Duval & 207 & St Johns River Power Park & 1,358 \\
\hline Duval & 667 & Northside Generating Station & $1,158.7$ \\
\hline Duval & 7846 & Brandy Branch & 228.1 \\
\hline Duval & 10672 & Cedar Bay Generating Company LP & 291.6 \\
\hline Escambia & 641 & Crist & $1,135.1$ \\
\hline Hardee & 7380 & Midulla Generating Station & 189 \\
\hline Hardee & 50949 & Hardee Power Station & 95.8 \\
\hline Hernando & 10333 & Central Power \& Lime & 125 \\
\hline Hillsborough & 645 & Big Bend & $1,822.5$ \\
\hline Hillsborough & 7873 & H L Culbreath Bayside Power Station & 685.1 \\
\hline Hillsborough & 50858 & Hillsborough County Resource Recovery & 47 \\
\hline Hillsborough & 50875 & McKay Bay Facility & 22.1 \\
\hline Indian River & 693 & Vero Beach Municipal Power Plant & 117 \\
\hline Jackson & 642 & Scholz & 98 \\
\hline Lake & 50629 & Covanta Lake County Energy & 15.5 \\
\hline Lake & 54423 & Lake Cogen Ltd & 31.1 \\
\hline Lee & 612 & Fort Myers & 592.3 \\
\hline Lee & 52010 & Lee County Solid Waste Energy & 59 \\
\hline Leon & 688 & Arvah B Hopkins & 334.2 \\
\hline Liberty & 50774 & Telogia Power & 14 \\
\hline Manatee & 6042 & Manatee & $2,198.4$ \\
\hline Martin & 6043 & Martin & $2,823.7$ \\
\hline Martin & 50976 & Indiantown Cogeneration LP & 395.4 \\
\hline Miami-Dade & 621 & Turkey Point & 2,796 \\
\hline Miami-Dade & 10062 & Miami Dade County Resource Recovery Fac & 77 \\
\hline Orange & 564 & Stanton Energy Center & $1,058.8$ \\
\hline Orange & 7294 & Central Energy Plant & 8.5 \\
\hline Orange & 54466 & Orlando Cogen LP & 122.4 \\
\hline Orange & 55821 & Curtis H Stanton Energy Center & 281.9 \\
\hline Osceola & 672 & Hansel & 20 \\
\hline Osceola & 7238 & Cane Island & 122.5 \\
\hline Palm Beach & 673 & Tom G Smith & 36.5 \\
\hline Palm Beach & 50071 & North County Regional Resource & 62.3 \\
\hline Palm Beach & 54627 & Okeelanta Cogeneration & 128.9 \\
\hline
\end{tabular}


Appendix 1. The 1,284 thermoelectric plants one megawatt nameplate capacity or greater with water-cooling systems in the United States, 2010.-Continued

[EIA, U.S. Department of Energy, Energy Information Administration; MW, megawatt; initials associated with a power plant are part of the plant name, and not spelled out; --, nameplate capacity is not reported for the steam side of the combined-cycle power plant]

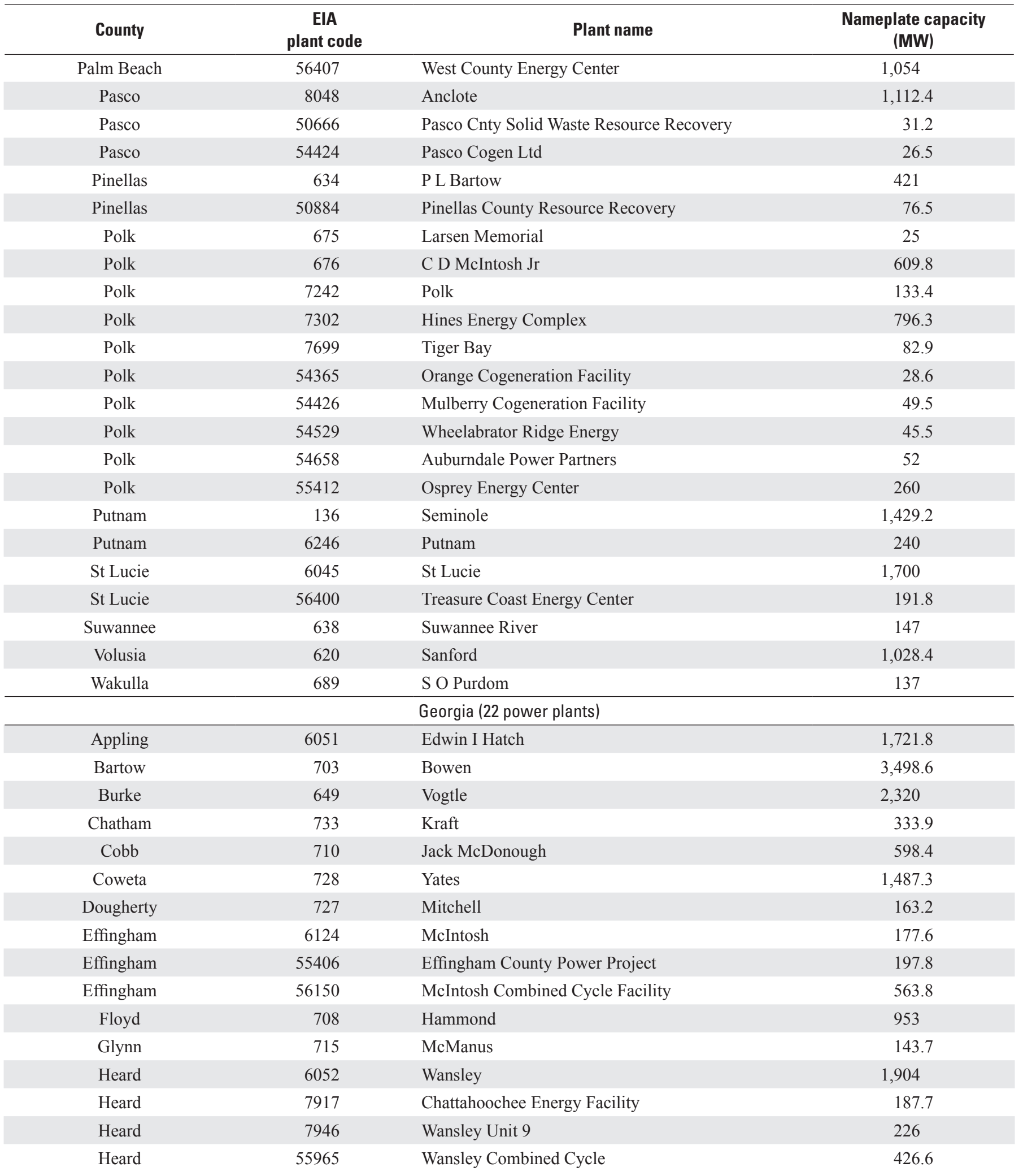


Appendix 1. The 1,284 thermoelectric plants one megawatt nameplate capacity or greater with water-cooling systems in the United States, 2010.-Continued

[EIA, U.S. Department of Energy, Energy Information Administration; MW, megawatt; initials associated with a power plant are part of the plant name, and not spelled out; --, nameplate capacity is not reported for the steam side of the combined-cycle power plant]

\begin{tabular}{|c|c|c|c|}
\hline County & $\begin{array}{c}\text { EIA } \\
\text { plant code }\end{array}$ & Plant name & $\begin{array}{l}\text { Nameplate capacity } \\
\text { (MW) }\end{array}$ \\
\hline Houston & 55040 & Mid-Georgia Cogeneration Facility & 110 \\
\hline Monroe & 6257 & Scherer & 3,564 \\
\hline Murray & 55382 & KGen Murray I and II LLC & 604 \\
\hline Putnam & 709 & Harllee Branch & $1,746.2$ \\
\hline Rabun & 50201 & Rabun Gap Cogen Facility & 20 \\
\hline \multirow[t]{2}{*}{ Worth } & 753 & Crisp Plant & 12.5 \\
\hline & & Hawaii (12 power plants) & \\
\hline Hawaii & 772 & W H Hill & 37.1 \\
\hline Hawaii & 6478 & Shipman & 15 \\
\hline Hawaii & 52028 & Puna Geothermal Venture I & 35 \\
\hline Hawaii & 55369 & Hamakua Energy Plant & 20 \\
\hline Honolulu & 764 & Honolulu & 104.4 \\
\hline Honolulu & 765 & Kahe & 609.7 \\
\hline Honolulu & 766 & Waiau & 372 \\
\hline Honolulu & 54646 & Kalaeola Cogen Plant & 61 \\
\hline Kauai & 6474 & Port Allen & 10 \\
\hline Maui & 6056 & Kahului & 34 \\
\hline Maui & 6504 & Maalaea & 36 \\
\hline \multirow[t]{2}{*}{ Oahu } & 10673 & AES Hawaii & 203 \\
\hline & & Idaho (4 power plants) & \\
\hline Adams & 50099 & Tamarack Energy Partnership & 6.2 \\
\hline Benewah & 55090 & Plummer Cogen & 6.2 \\
\hline Kootenai & 55179 & Rathdrum Power LLC & 122.1 \\
\hline \multirow[t]{2}{*}{ Minidoka } & 54579 & Rupert Cogen Project & 10.4 \\
\hline & & Illinois (37 power plants) & \\
\hline Christian & 876 & Kincaid Generation LLC & 1,319 \\
\hline Cook & 867 & Crawford & 597.4 \\
\hline Cook & 886 & Fisk Street & 374 \\
\hline Cook & 972 & Winnetka & 28.2 \\
\hline Cook & 55174 & Geneva Energy LLC & 22 \\
\hline Crawford & 863 & Hutsonville & 150 \\
\hline De Witt & 204 & Clinton Power Station & $1,138.3$ \\
\hline Douglas & 55245 & Tuscola Station & 12 \\
\hline Fulton & 6016 & Duck Creek & 441 \\
\hline Grundy & 869 & Dresden Generating Station & $2,018.6$ \\
\hline Grundy & 55216 & Morris Cogeneration LLC & 62 \\
\hline Jackson & 862 & Grand Tower & 199.3 \\
\hline Jasper & 6017 & Newton & $1,234.8$ \\
\hline Kendall & 55131 & Kendall County Generation Facility & 536 \\
\hline La Salle & 6026 & LaSalle Generating Station & 2,340 \\
\hline
\end{tabular}


Appendix 1. The 1,284 thermoelectric plants one megawatt nameplate capacity or greater with water-cooling systems in the United States, 2010.-Continued

[EIA, U.S. Department of Energy, Energy Information Administration; MW, megawatt; initials associated with a power plant are part of the plant name, and not spelled out; --, nameplate capacity is not reported for the steam side of the combined-cycle power plant]

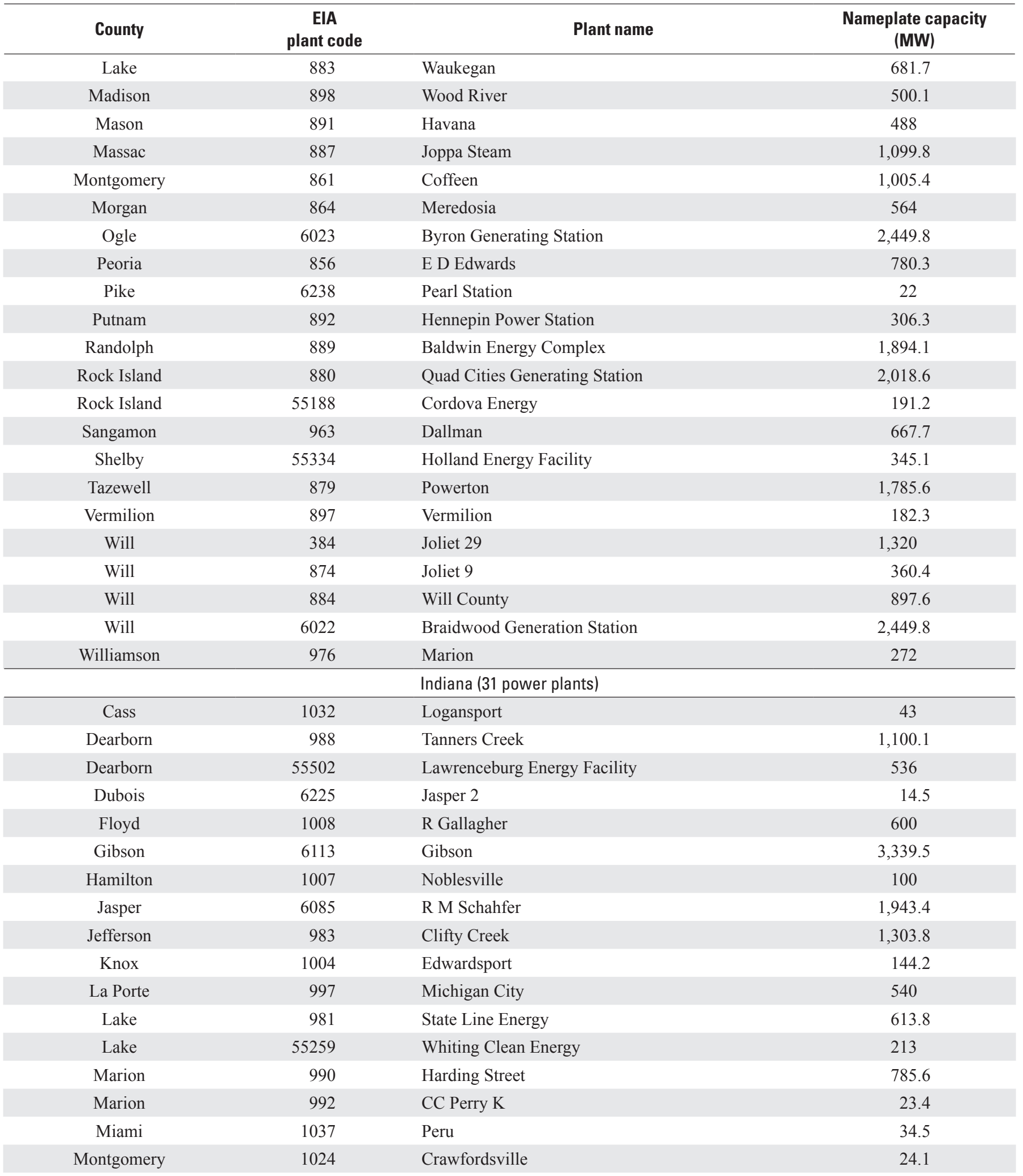


Appendix 1. The 1,284 thermoelectric plants one megawatt nameplate capacity or greater with water-cooling systems in the United States, 2010.-Continued

[EIA, U.S. Department of Energy, Energy Information Administration; MW, megawatt; initials associated with a power plant are part of the plant name, and not spelled out; --, nameplate capacity is not reported for the steam side of the combined-cycle power plant]

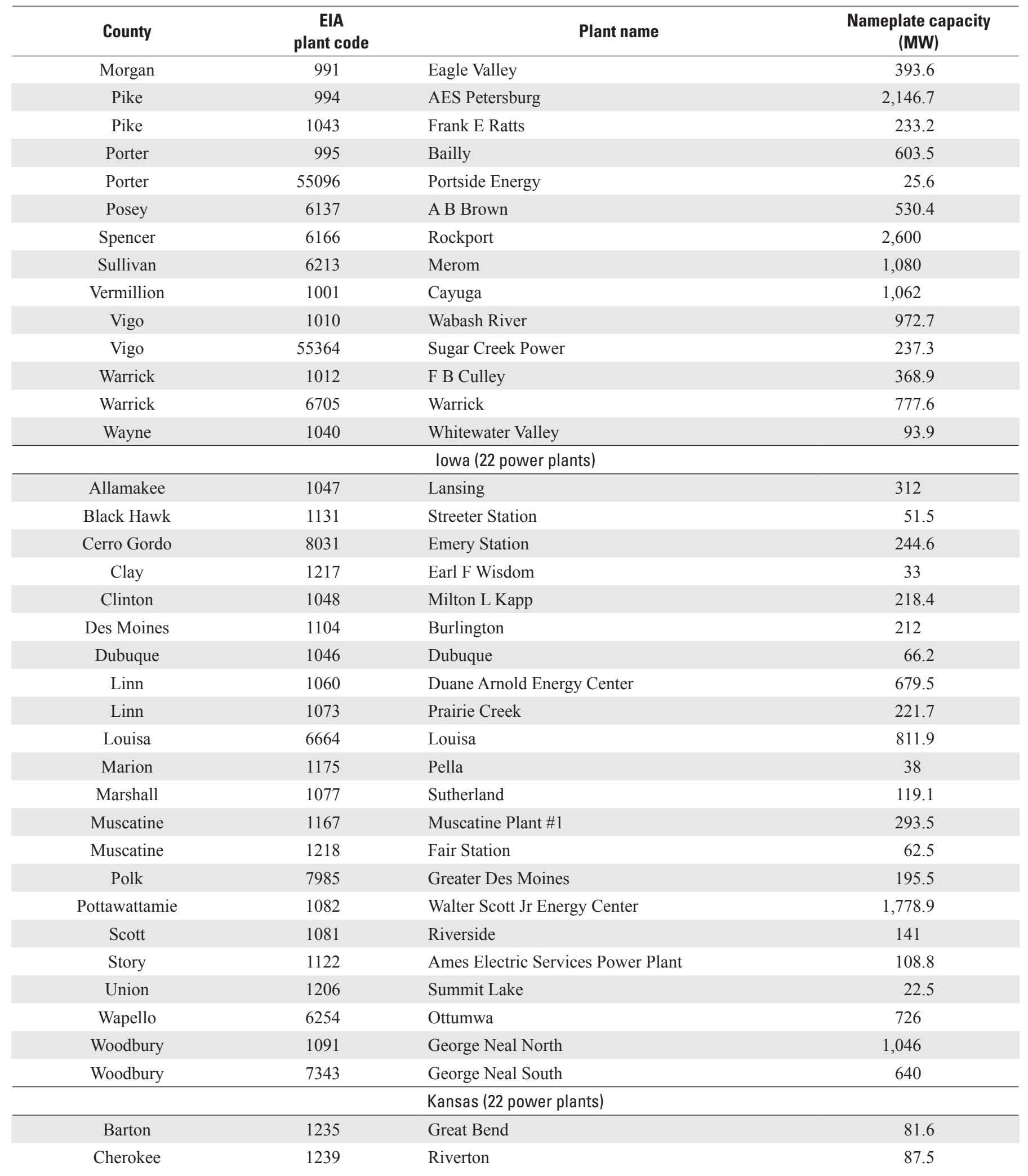


Appendix 1. The 1,284 thermoelectric plants one megawatt nameplate capacity or greater with water-cooling systems in the United States, 2010.-Continued

[EIA, U.S. Department of Energy, Energy Information Administration; MW, megawatt; initials associated with a power plant are part of the plant name, and not spelled out; --, nameplate capacity is not reported for the steam side of the combined-cycle power plant]

\begin{tabular}{|c|c|c|c|}
\hline County & $\begin{array}{c}\text { EIA } \\
\text { plant code }\end{array}$ & Plant name & $\begin{array}{l}\text { Nameplate capacity } \\
\text { (MW) }\end{array}$ \\
\hline Clay & 1270 & Clay Center & 8 \\
\hline Coffey & 210 & Wolf Creek Generating Station & $1,235.7$ \\
\hline Cowley & 7013 & East 12 th Street & 26.5 \\
\hline Douglas & 1250 & Lawrence Energy Center & 566 \\
\hline Ford & 1233 & Fort Dodge & 149 \\
\hline Labette & 1243 & Neosho & 69 \\
\hline Linn & 1241 & La Cygne & 1,578 \\
\hline Montgomery & 1271 & Coffeyville & 58.7 \\
\hline Sedgwick & 1240 & Gordon Evans Energy Center & 526 \\
\hline Sedgwick & 1242 & Murray Gill & 349 \\
\hline Seward & 1230 & Cimarron River & 50 \\
\hline Shawnee & 1252 & Tecumseh Energy Center & 232 \\
\hline Sumner & 1330 & Wellington 1 & 20 \\
\hline Wyandotte & 1295 & Quindaro & 239.1 \\
\hline Wyandotte & 6064 & Nearman Creek & 261 \\
\hline \multicolumn{4}{|c|}{ Kentucky (20 power plants) } \\
\hline Boone & 6018 & East Bend & 669.3 \\
\hline Jefferson & 1364 & Mill Creek & $1,717.2$ \\
\hline Lawrence & 1353 & Big Sandy & $1,096.8$ \\
\hline Mason & 6041 & H L Spurlock & $1,608.5$ \\
\hline McCracken & 1379 & Shawnee & 1,750 \\
\hline Mercer & 1355 & E W Brown & 757.1 \\
\hline Muhlenberg & 1357 & Green River & 188.6 \\
\hline Muhlenberg & 1378 & Paradise & $2,558.2$ \\
\hline Ohio & 6823 & D B Wilson & 566.1 \\
\hline Pulaski & 1384 & Cooper & 344 \\
\hline Trimble & 6071 & Trimble County & 566.1 \\
\hline Webster & 1383 & Robert A Reid & 96 \\
\hline Webster & 6639 & R D Green & 586 \\
\hline Woodford & 1361 & Tyrone & 75 \\
\hline
\end{tabular}


Appendix 1. The 1,284 thermoelectric plants one megawatt nameplate capacity or greater with water-cooling systems in the United States, 2010.-Continued

[EIA, U.S. Department of Energy, Energy Information Administration; MW, megawatt; initials associated with a power plant are part of the plant name, and not spelled out; --, nameplate capacity is not reported for the steam side of the combined-cycle power plant]

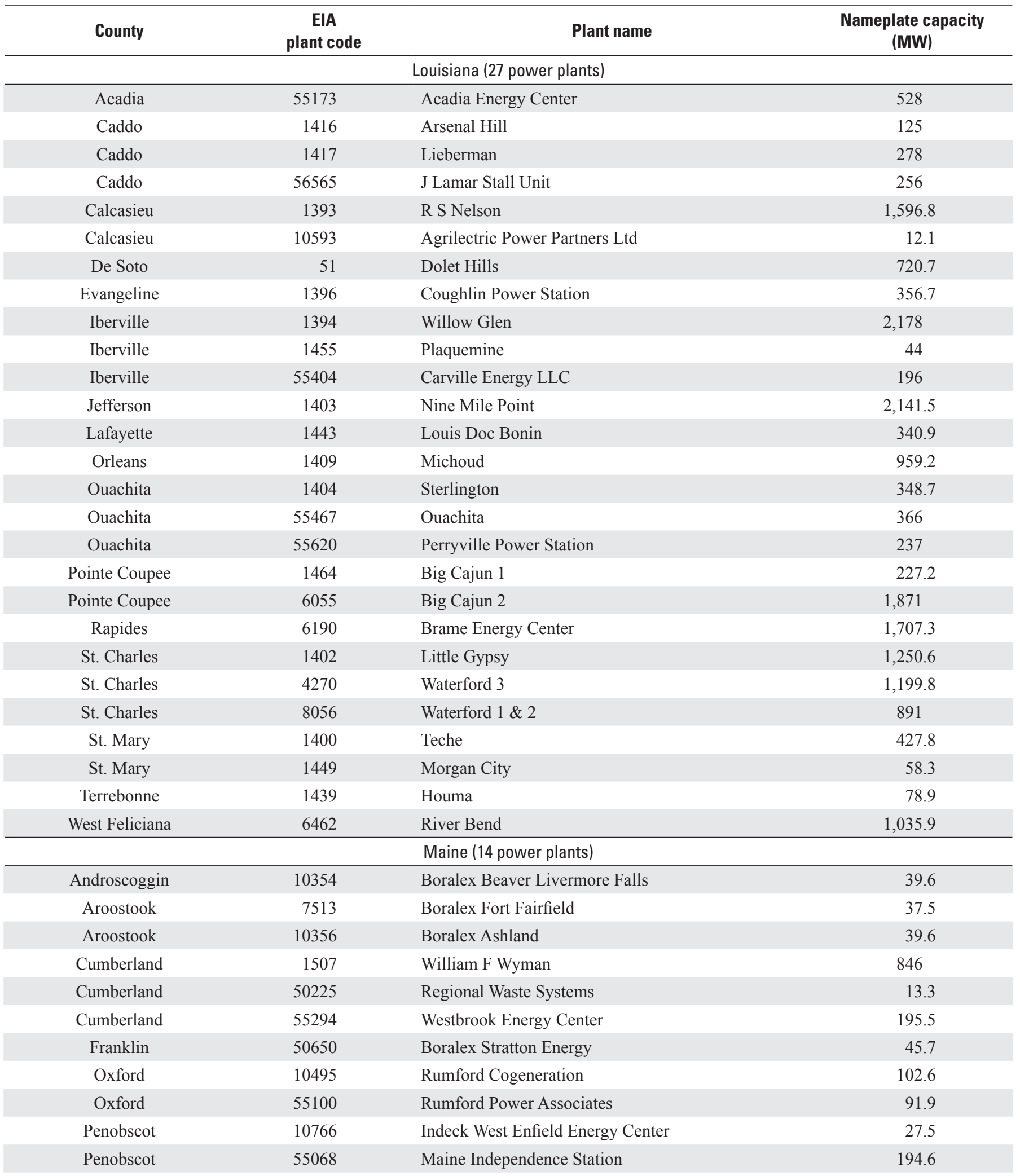


Appendix 1. The 1,284 thermoelectric plants one megawatt nameplate capacity or greater with water-cooling systems in the United States, 2010.-Continued

[EIA, U.S. Department of Energy, Energy Information Administration; MW, megawatt; initials associated with a power plant are part of the plant name, and not spelled out; --, nameplate capacity is not reported for the steam side of the combined-cycle power plant]

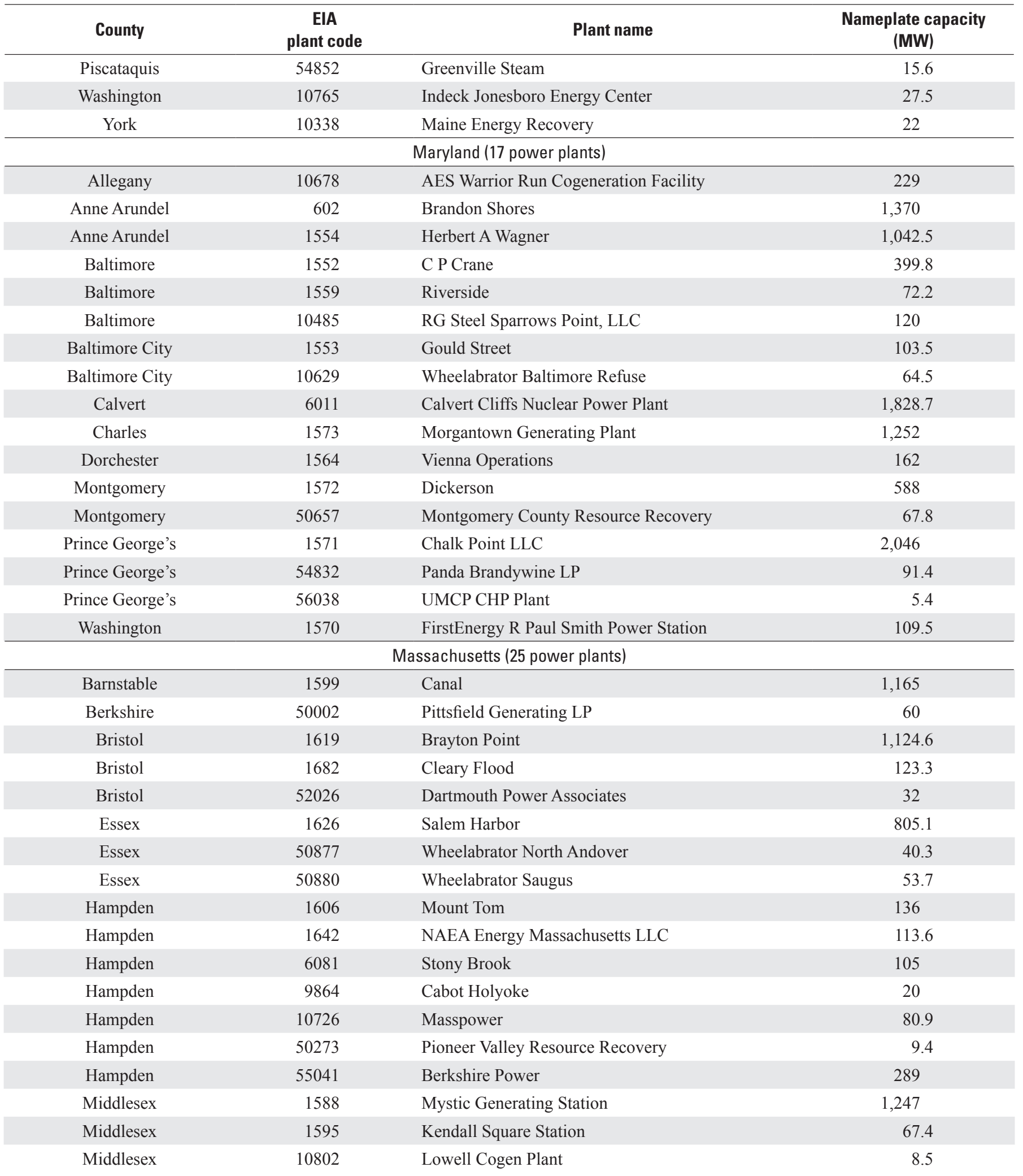


Appendix 1. The 1,284 thermoelectric plants one megawatt nameplate capacity or greater with water-cooling systems in the United States, 2010.-Continued

[EIA, U.S. Department of Energy, Energy Information Administration; MW, megawatt; initials associated with a power plant are part of the plant name, and not spelled out; --, nameplate capacity is not reported for the steam side of the combined-cycle power plant]

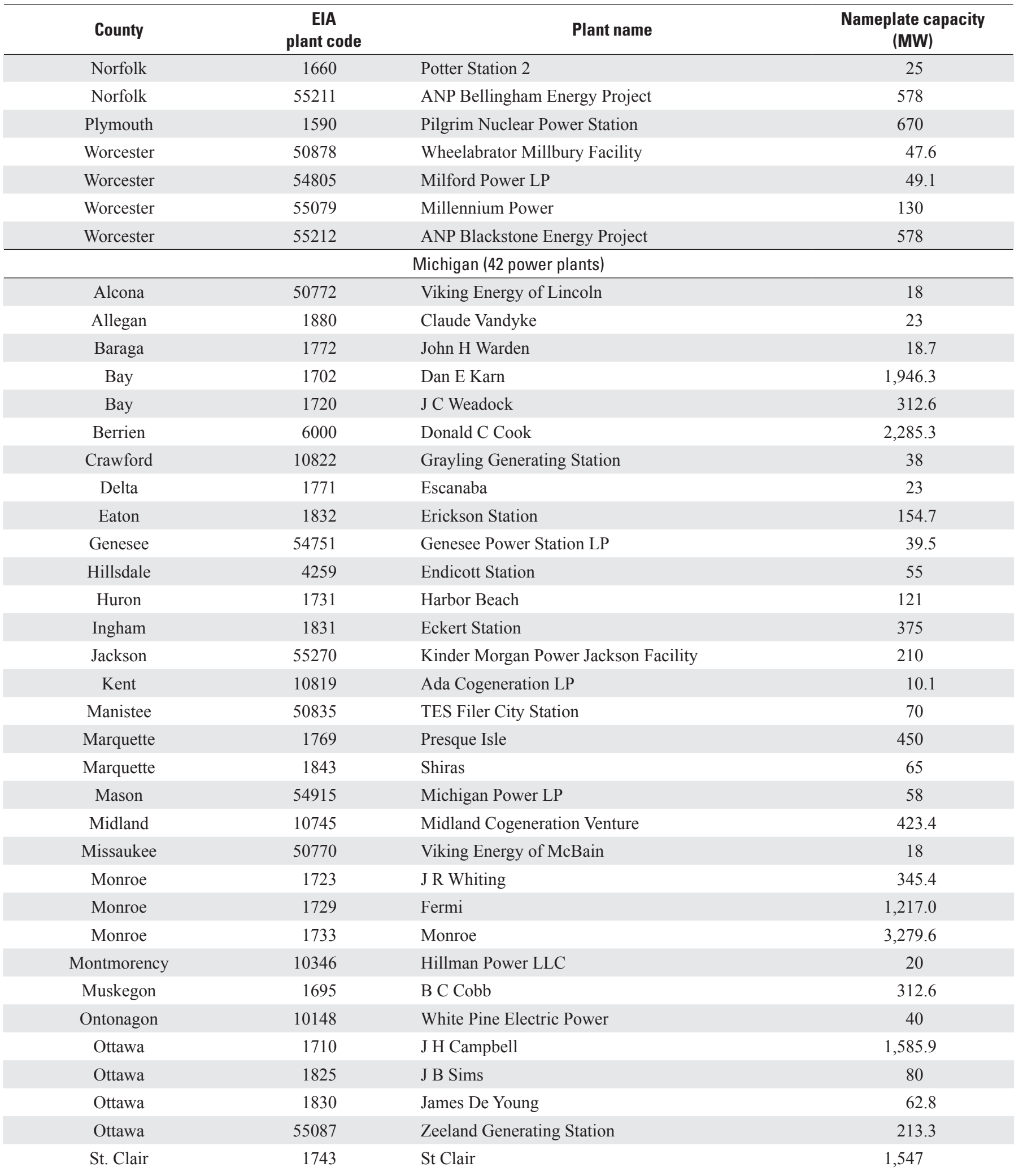


Appendix 1. The 1,284 thermoelectric plants one megawatt nameplate capacity or greater with water-cooling systems in the United States, 2010.-Continued

[EIA, U.S. Department of Energy, Energy Information Administration; MW, megawatt; initials associated with a power plant are part of the plant name, and not spelled out; --, nameplate capacity is not reported for the steam side of the combined-cycle power plant]

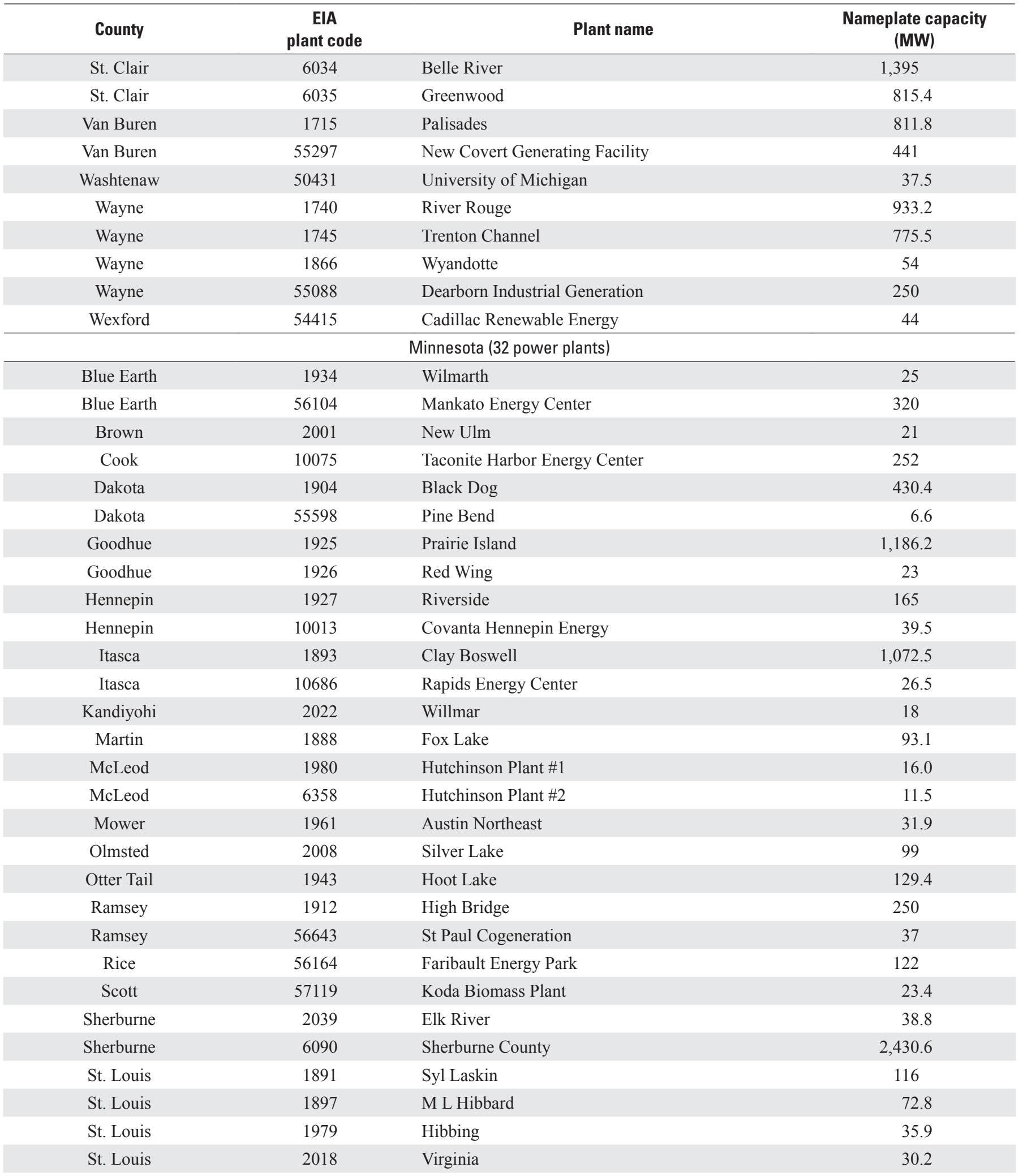


Appendix 1. The 1,284 thermoelectric plants one megawatt nameplate capacity or greater with water-cooling systems in the United States, 2010.-Continued

[EIA, U.S. Department of Energy, Energy Information Administration; MW, megawatt; initials associated with a power plant are part of the plant name, and not spelled out; --, nameplate capacity is not reported for the steam side of the combined-cycle power plant]

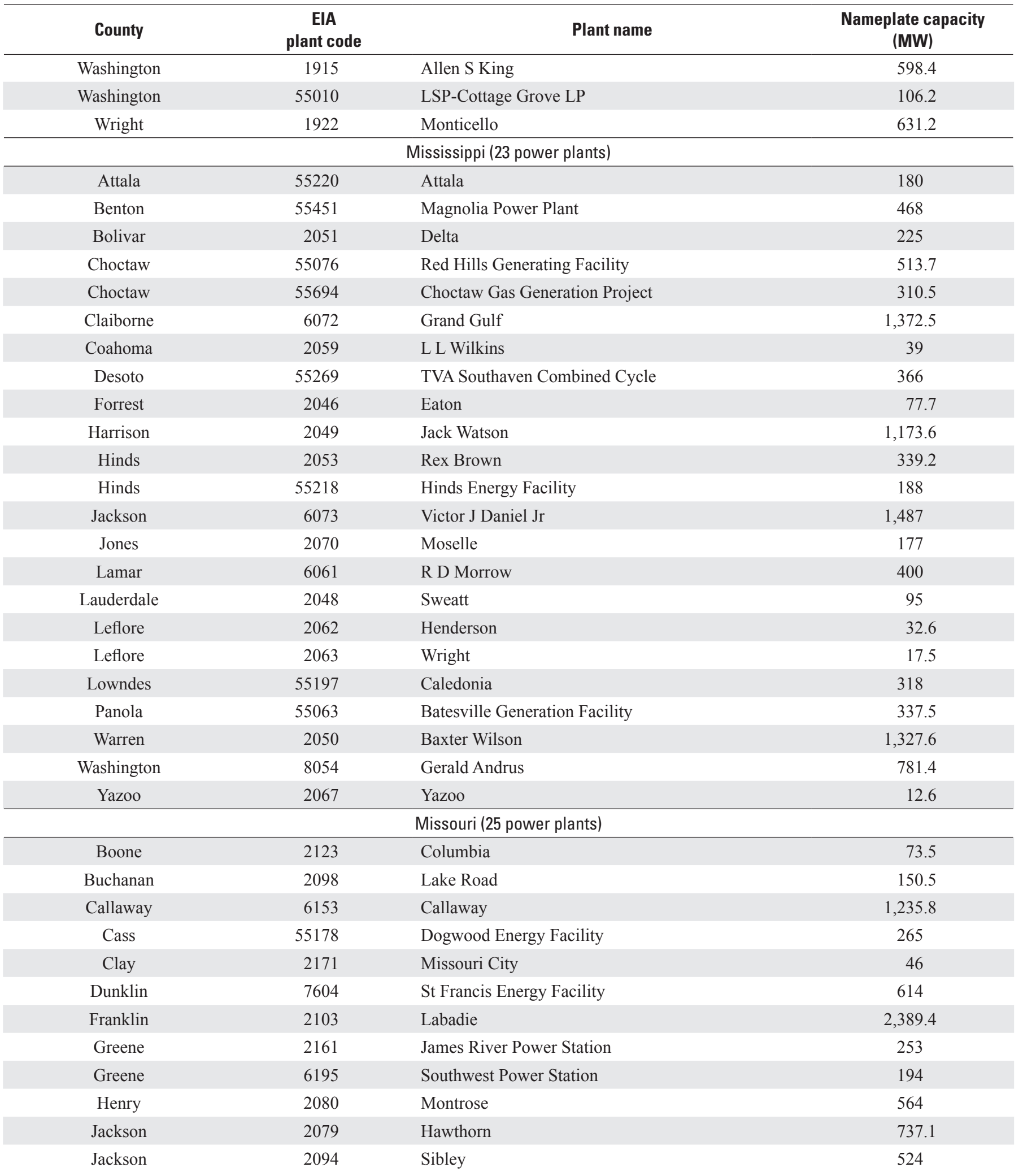


Appendix 1. The 1,284 thermoelectric plants one megawatt nameplate capacity or greater with water-cooling systems in the United States, 2010.-Continued

[EIA, U.S. Department of Energy, Energy Information Administration; MW, megawatt; initials associated with a power plant are part of the plant name, and not spelled out; --, nameplate capacity is not reported for the steam side of the combined-cycle power plant]

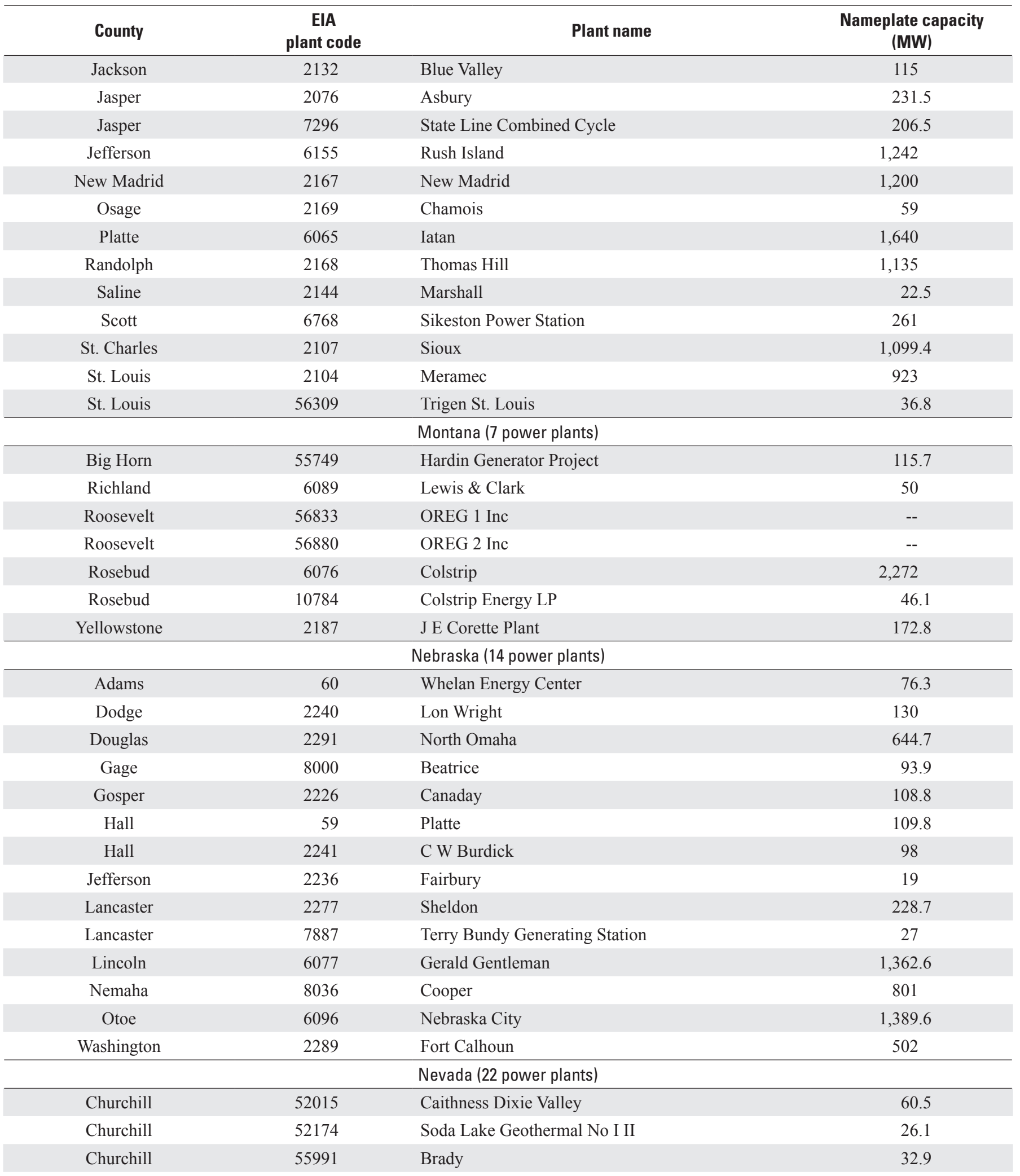


Appendix 1. The 1,284 thermoelectric plants one megawatt nameplate capacity or greater with water-cooling systems in the United States, 2010.-Continued

[EIA, U.S. Department of Energy, Energy Information Administration; MW, megawatt; initials associated with a power plant are part of the plant name, and not spelled out; --, nameplate capacity is not reported for the steam side of the combined-cycle power plant]

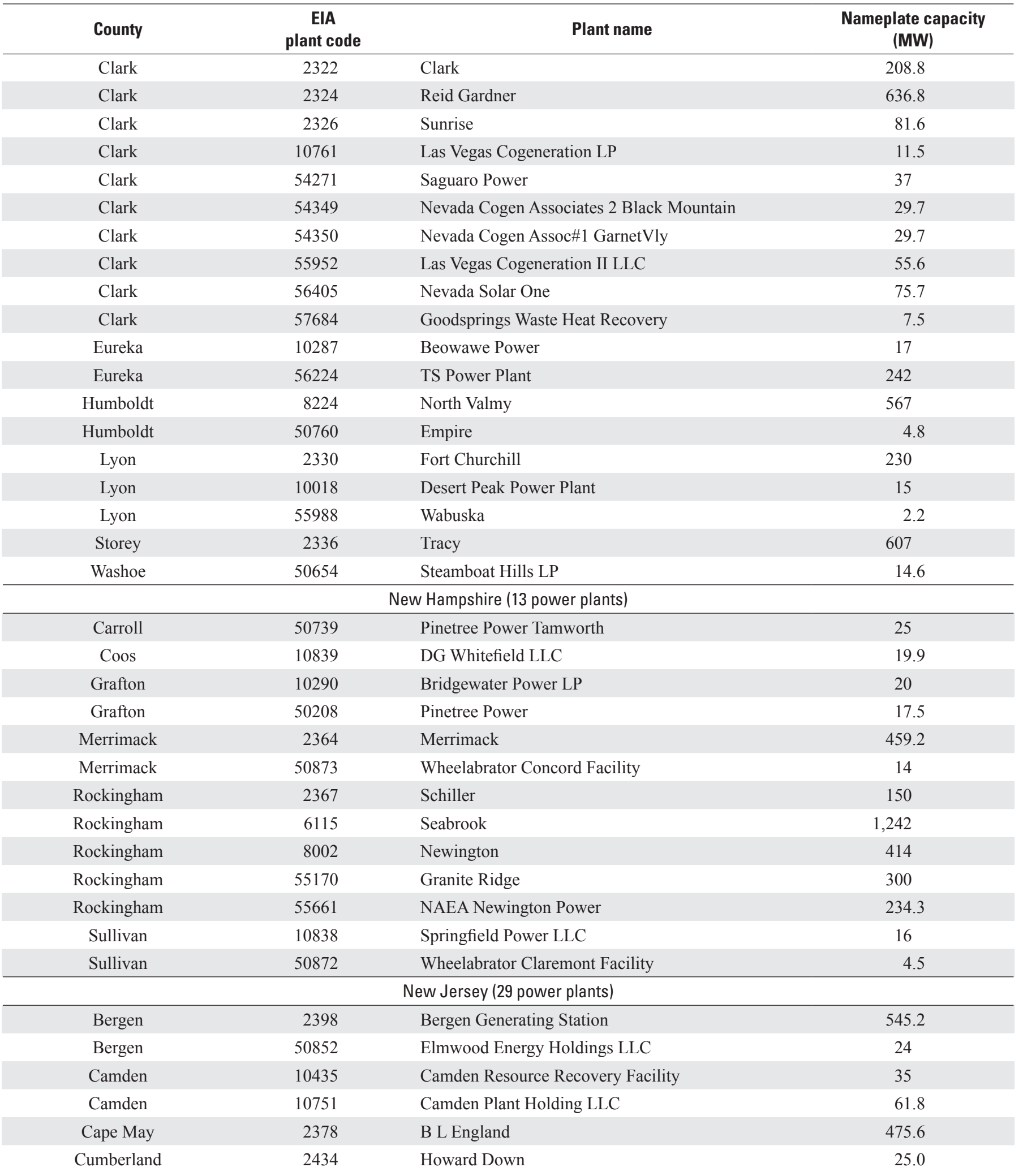


Appendix 1. The 1,284 thermoelectric plants one megawatt nameplate capacity or greater with water-cooling systems in the United States, 2010.-Continued

[EIA, U.S. Department of Energy, Energy Information Administration; MW, megawatt; initials associated with a power plant are part of the plant name, and not spelled out; --, nameplate capacity is not reported for the steam side of the combined-cycle power plant]

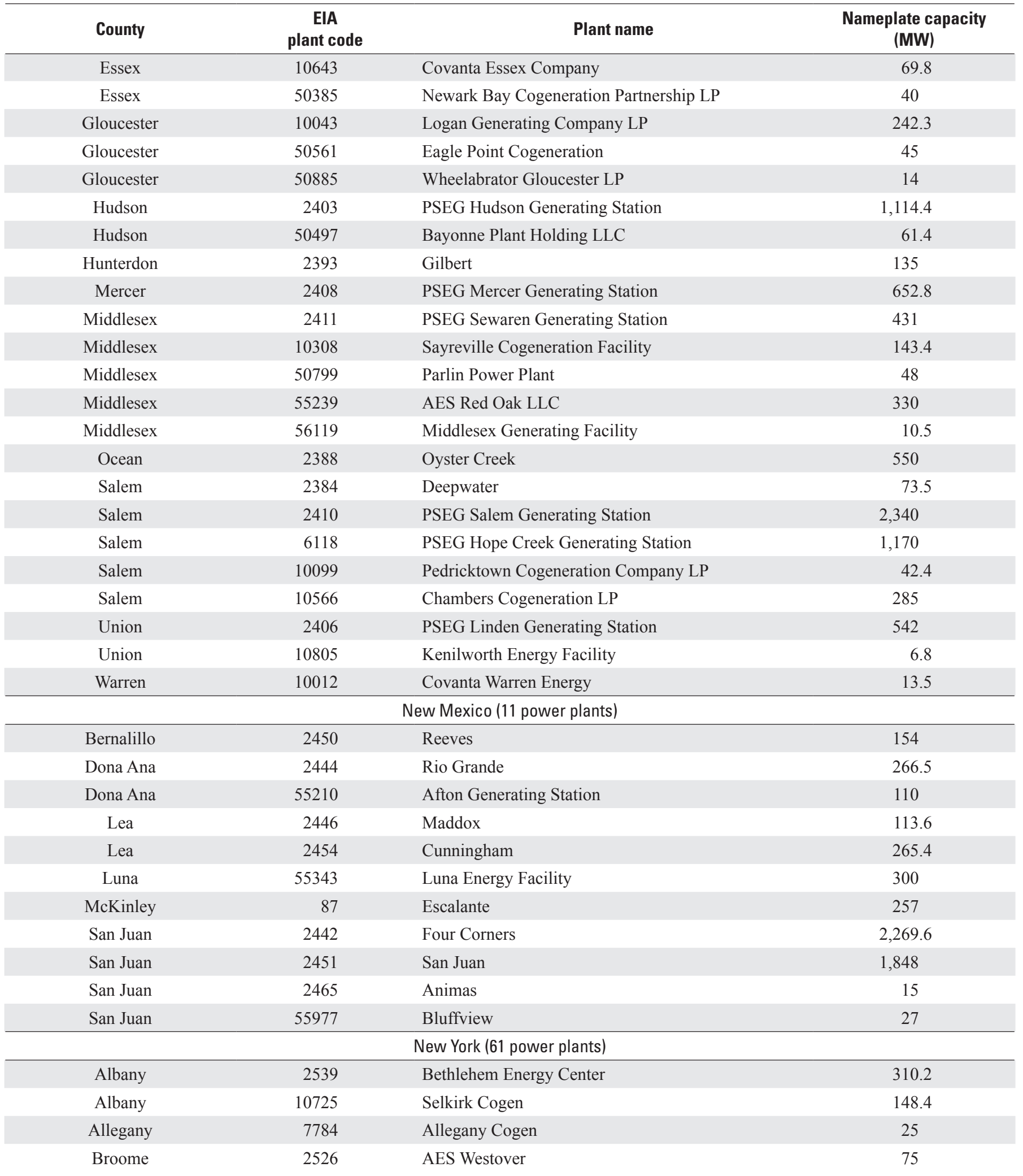


Appendix 1. The 1,284 thermoelectric plants one megawatt nameplate capacity or greater with water-cooling systems in the United States, 2010.-Continued

[EIA, U.S. Department of Energy, Energy Information Administration; MW, megawatt; initials associated with a power plant are part of the plant name, and not spelled out; --, nameplate capacity is not reported for the steam side of the combined-cycle power plant]

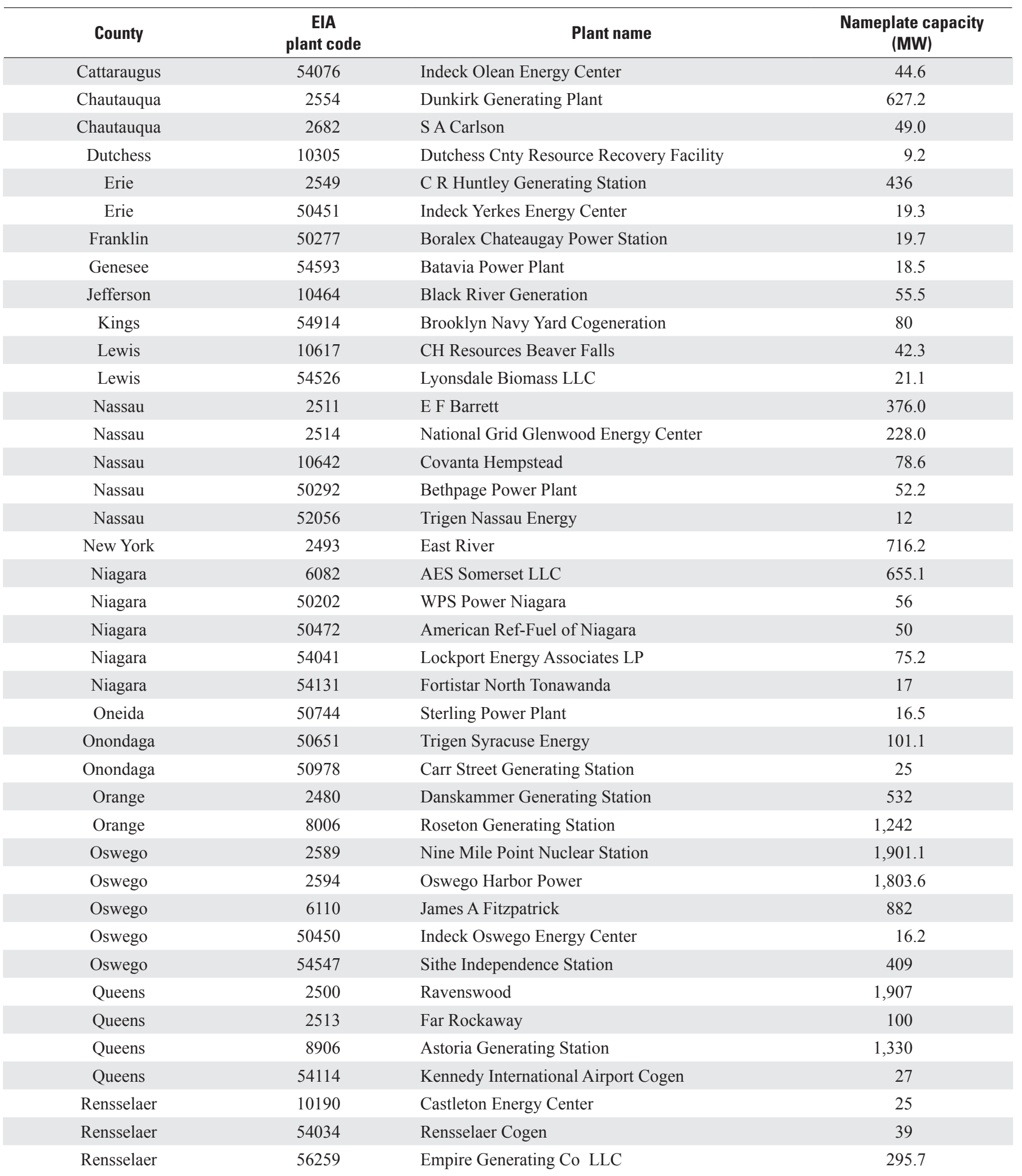


Appendix 1. The 1,284 thermoelectric plants one megawatt nameplate capacity or greater with water-cooling systems in the United States, 2010.-Continued

[EIA, U.S. Department of Energy, Energy Information Administration; MW, megawatt; initials associated with a power plant are part of the plant name, and not spelled out; --, nameplate capacity is not reported for the steam side of the combined-cycle power plant]

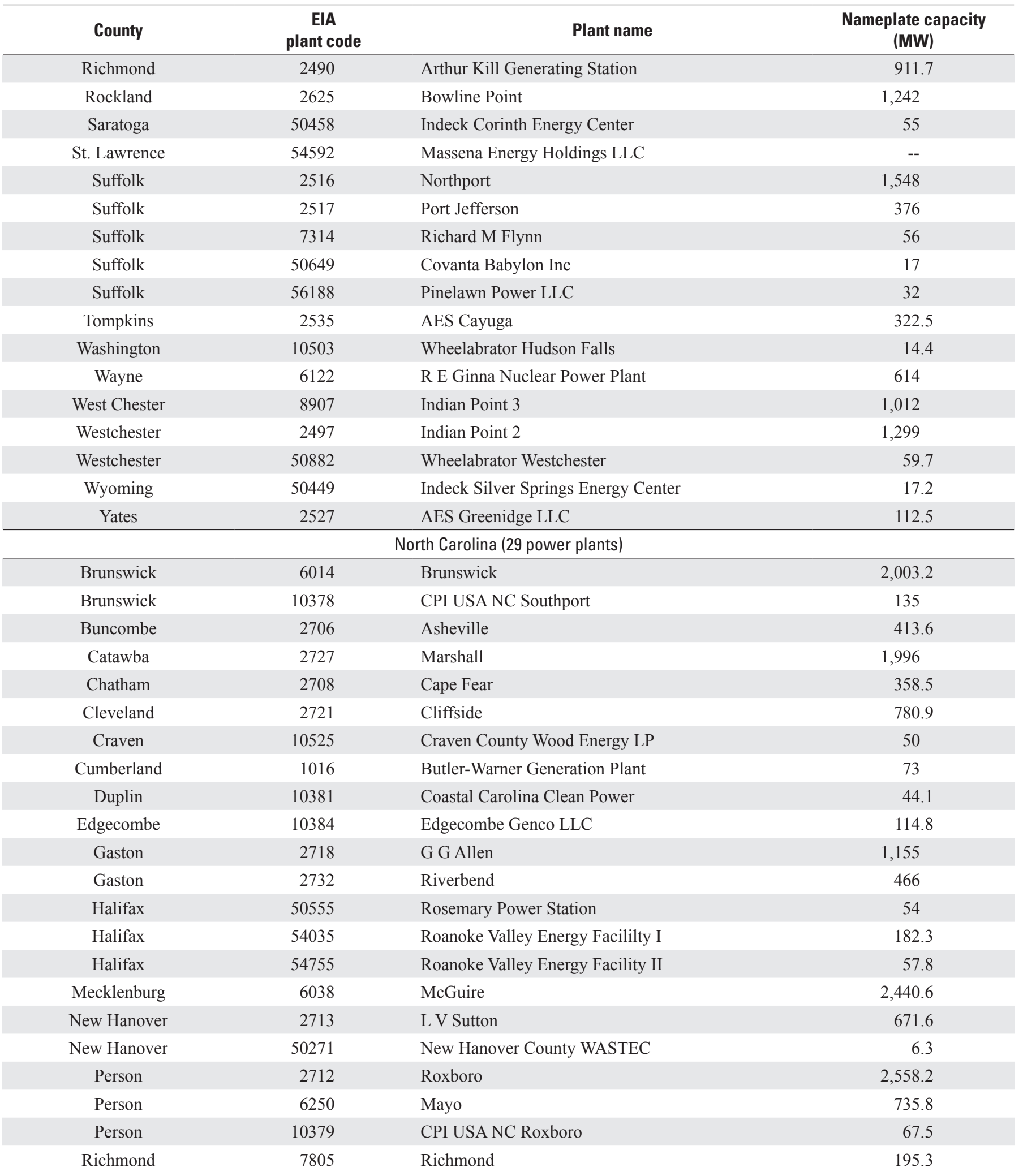


Appendix 1. The 1,284 thermoelectric plants one megawatt nameplate capacity or greater with water-cooling systems in the United States, 2010.-Continued

[EIA, U.S. Department of Energy, Energy Information Administration; MW, megawatt; initials associated with a power plant are part of the plant name, and not spelled out; --, nameplate capacity is not reported for the steam side of the combined-cycle power plant]

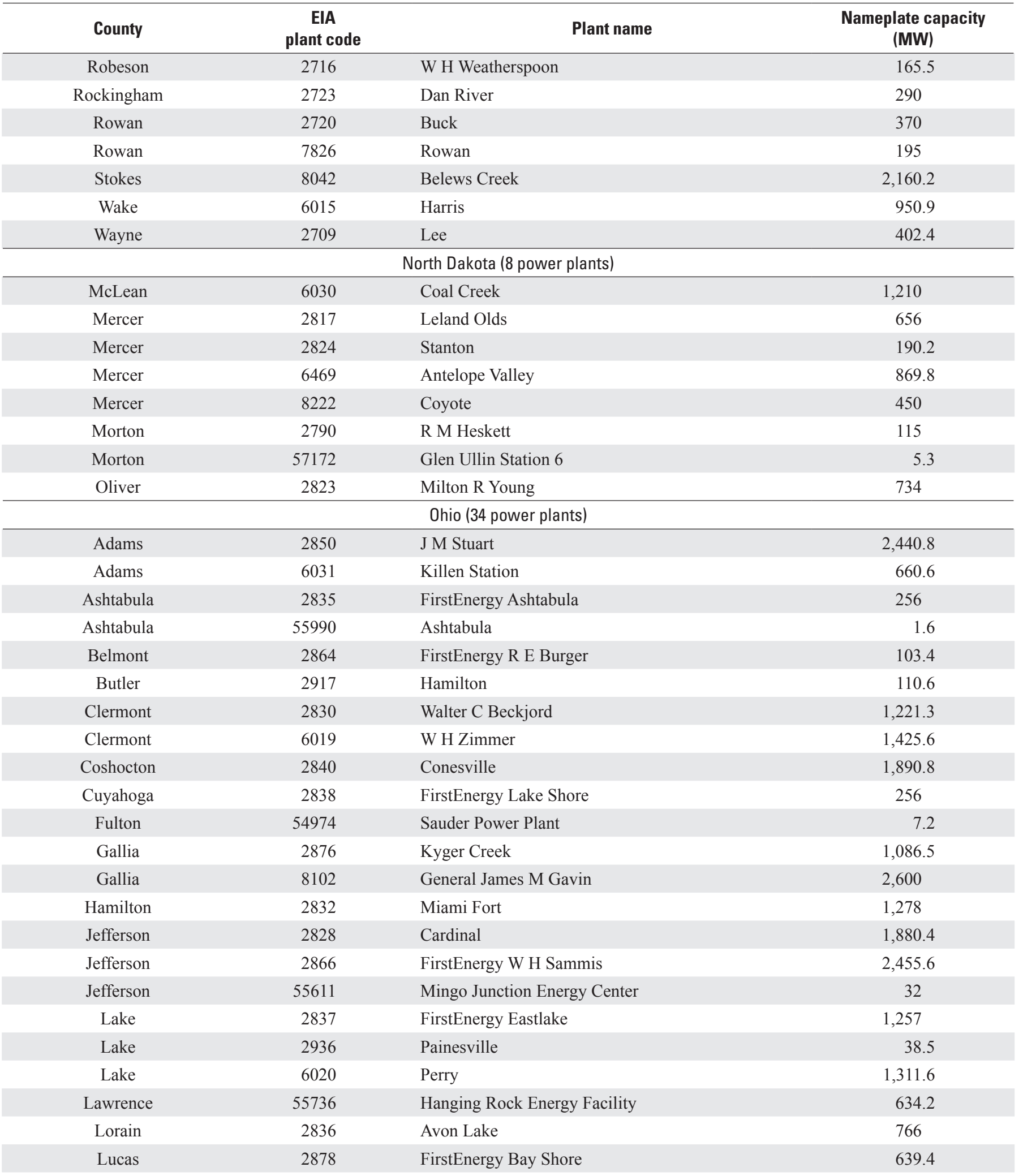


Appendix 1. The 1,284 thermoelectric plants one megawatt nameplate capacity or greater with water-cooling systems in the United States, 2010.-Continued

[EIA, U.S. Department of Energy, Energy Information Administration; MW, megawatt; initials associated with a power plant are part of the plant name, and not spelled out; --, nameplate capacity is not reported for the steam side of the combined-cycle power plant]

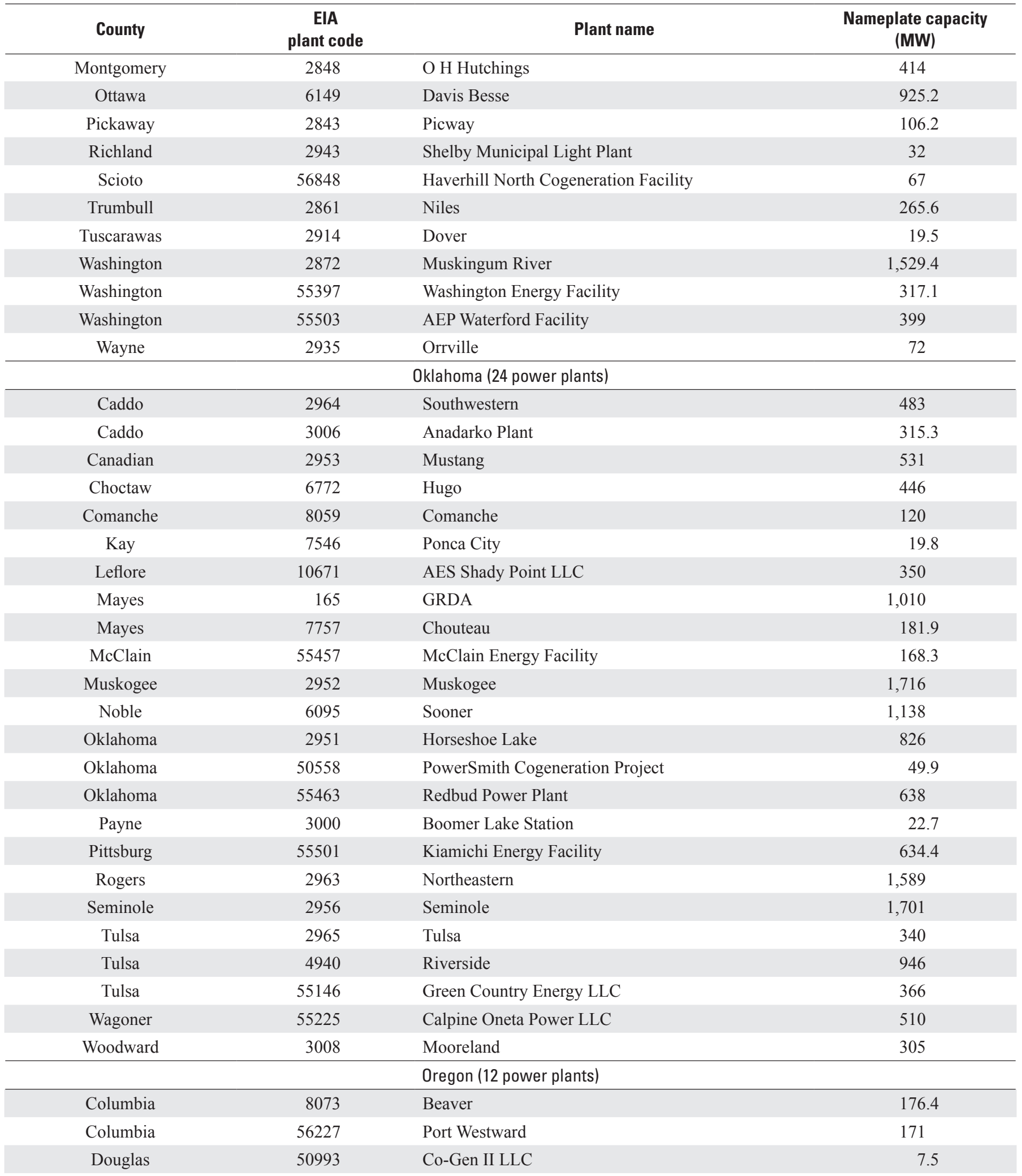


Appendix 1. The 1,284 thermoelectric plants one megawatt nameplate capacity or greater with water-cooling systems in the United States, 2010.-Continued

[EIA, U.S. Department of Energy, Energy Information Administration; MW, megawatt; initials associated with a power plant are part of the plant name, and not spelled out; --, nameplate capacity is not reported for the steam side of the combined-cycle power plant]

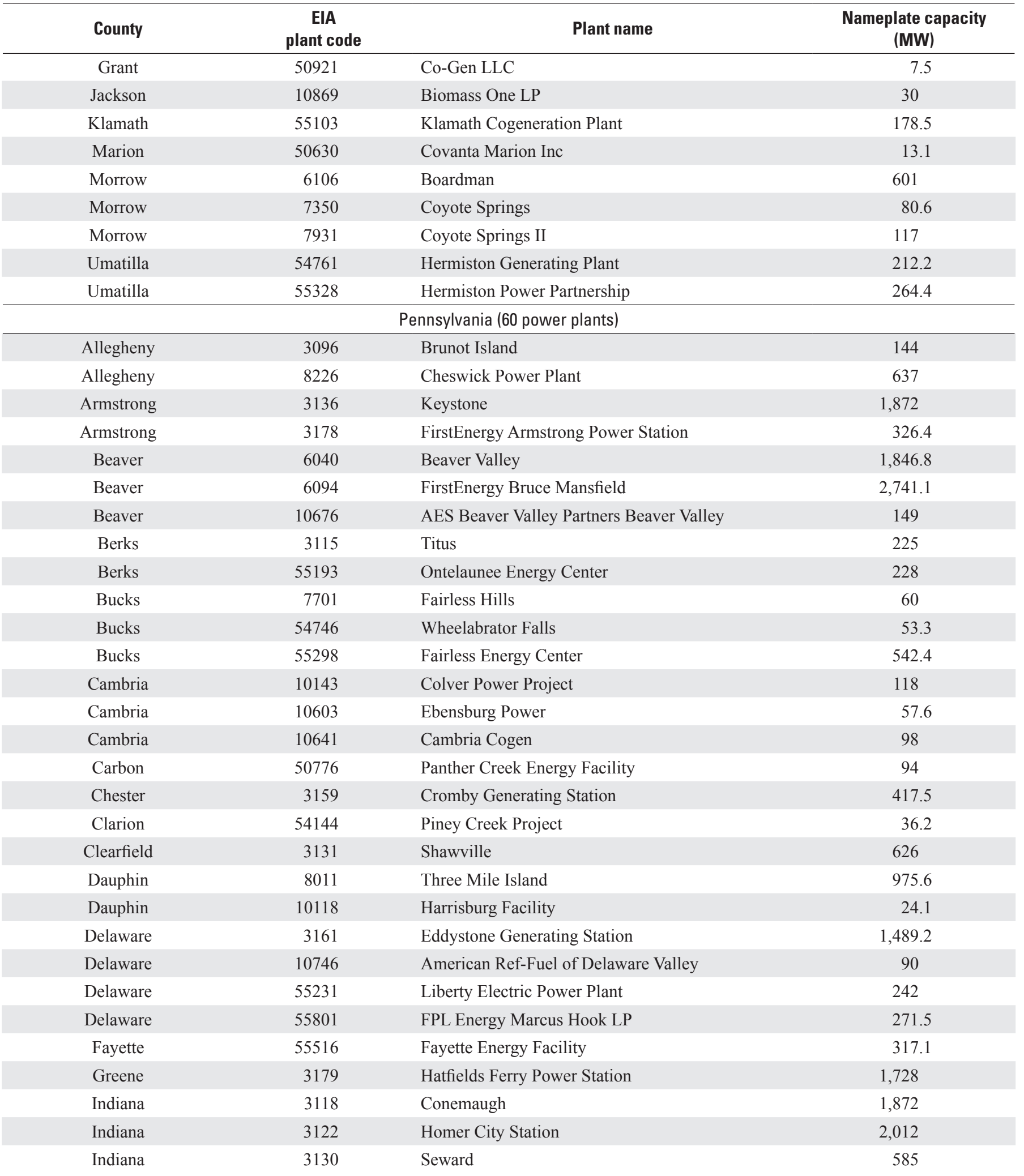


Appendix 1. The 1,284 thermoelectric plants one megawatt nameplate capacity or greater with water-cooling systems in the United States, 2010.-Continued

[EIA, U.S. Department of Energy, Energy Information Administration; MW, megawatt; initials associated with a power plant are part of the plant name, and not spelled out; --, nameplate capacity is not reported for the steam side of the combined-cycle power plant]

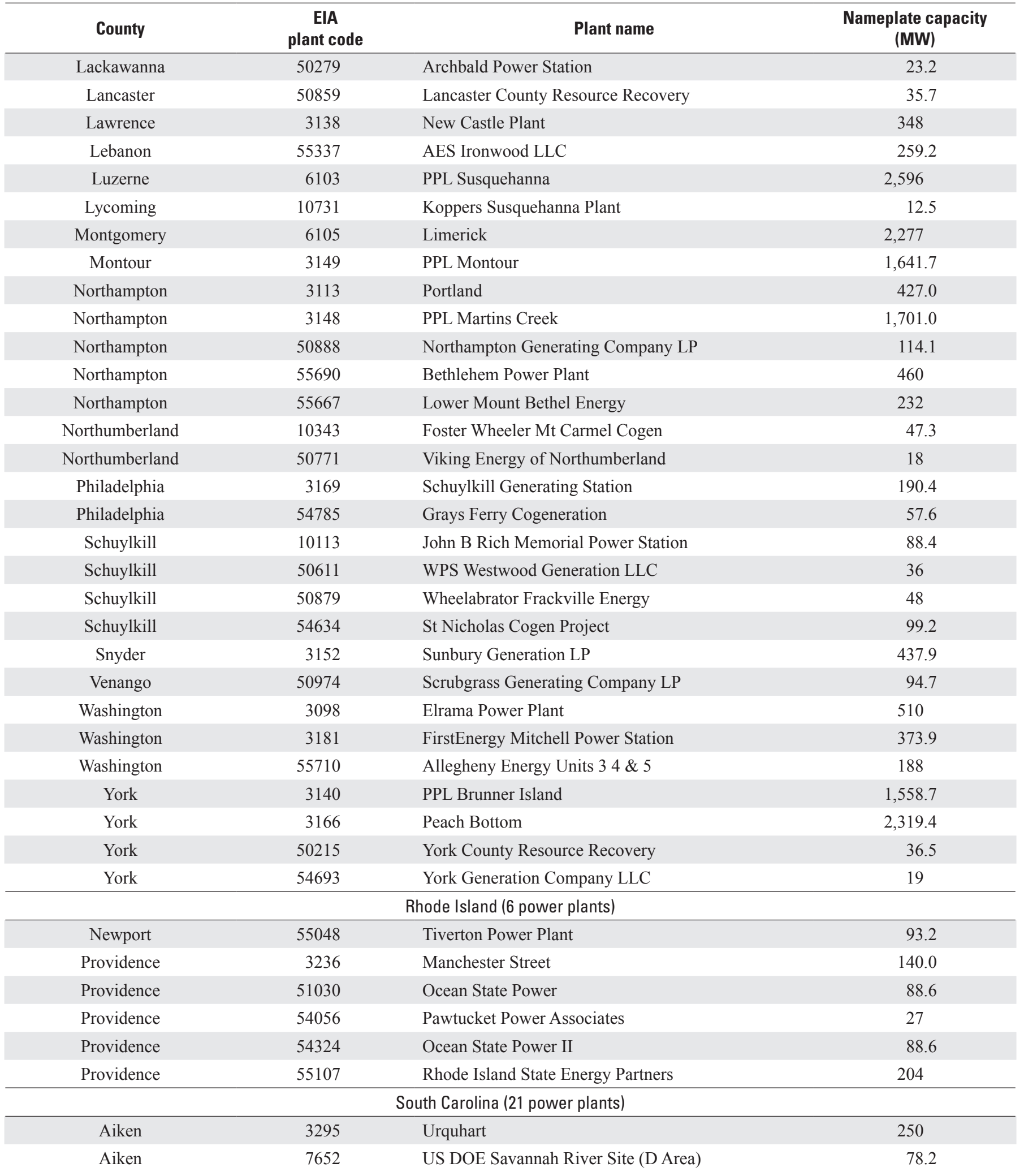


Appendix 1. The 1,284 thermoelectric plants one megawatt nameplate capacity or greater with water-cooling systems in the United States, 2010.-Continued

[EIA, U.S. Department of Energy, Energy Information Administration; MW, megawatt; initials associated with a power plant are part of the plant name, and not spelled out; --, nameplate capacity is not reported for the steam side of the combined-cycle power plant]

\begin{tabular}{|c|c|c|c|}
\hline County & $\begin{array}{c}\text { EIA } \\
\text { plant code }\end{array}$ & Plant name & $\begin{array}{c}\text { Nameplate capacity } \\
\text { (MW) }\end{array}$ \\
\hline Anderson & 3264 & W S Lee & 355 \\
\hline Anderson & 7834 & John S Rainey & 190 \\
\hline Berkeley & 130 & Cross & $2,390.1$ \\
\hline Berkeley & 3298 & Williams & 632.7 \\
\hline Charleston & 7737 & Cogen South & 99.2 \\
\hline Cherokee & 55043 & Cherokee County Cogen & 41.2 \\
\hline Colleton & 3280 & Canadys Steam & 489.6 \\
\hline Darlington & 3251 & H B Robinson & 975.2 \\
\hline Jasper & 55927 & Jasper & 405 \\
\hline Lexington & 3287 & McMeekin & 293.6 \\
\hline Oconee & 3265 & Oconee & $2,666.7$ \\
\hline Orangeburg & 7210 & Cope & 417.3 \\
\hline Richland & 3297 & Wateree & 771.8 \\
\hline York & 6036 & Catawba & $2,410.2$ \\
\hline \multicolumn{4}{|c|}{ South Dakota (2 power plants) } \\
\hline Grant & 6098 & Big Stone & 456 \\
\hline Pennington & 3325 & Ben French & 25 \\
\hline Rhea & 7722 & Watts Bar Nuclear Plant & $1,269.9$ \\
\hline Roane & 3407 & Kingston & 1,700 \\
\hline Shelby & 3393 & Allen Steam Plant & 990 \\
\hline Stewart & 3399 & Cumberland & 2,600 \\
\hline Sumner & 3403 & Gallatin & $1,255.2$ \\
\hline \multicolumn{4}{|c|}{ Texas (111 power plants) } \\
\hline Atascosa & 6183 & San Miguel & 410 \\
\hline Bastrop & 3601 & Sim Gideon & 639 \\
\hline Bastrop & 55154 & Lost Pines 1 Power Project & 204 \\
\hline Bastrop & 55168 & Bastrop Energy Center & 285 \\
\hline Bexar & 3609 & Leon Creek & 188.7 \\
\hline Bexar & 3611 & O W Sommers & 892 \\
\hline
\end{tabular}


Appendix 1. The 1,284 thermoelectric plants one megawatt nameplate capacity or greater with water-cooling systems in the United States, 2010.-Continued

[EIA, U.S. Department of Energy, Energy Information Administration; MW, megawatt; initials associated with a power plant are part of the plant name, and not spelled out; --, nameplate capacity is not reported for the steam side of the combined-cycle power plant]

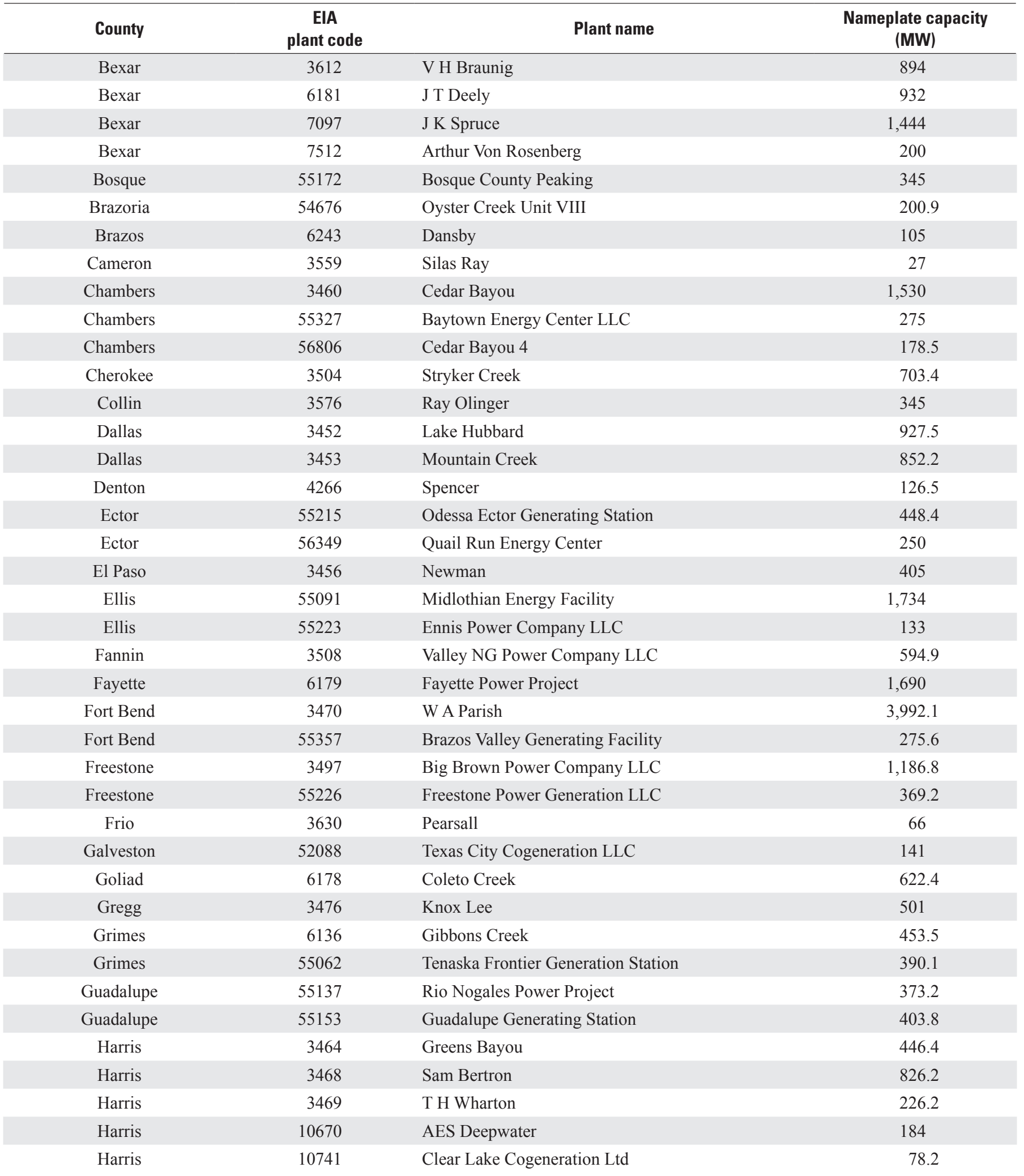


Appendix 1. The 1,284 thermoelectric plants one megawatt nameplate capacity or greater with water-cooling systems in the United States, 2010.-Continued

[EIA, U.S. Department of Energy, Energy Information Administration; MW, megawatt; initials associated with a power plant are part of the plant name, and not spelled out; --, nameplate capacity is not reported for the steam side of the combined-cycle power plant]

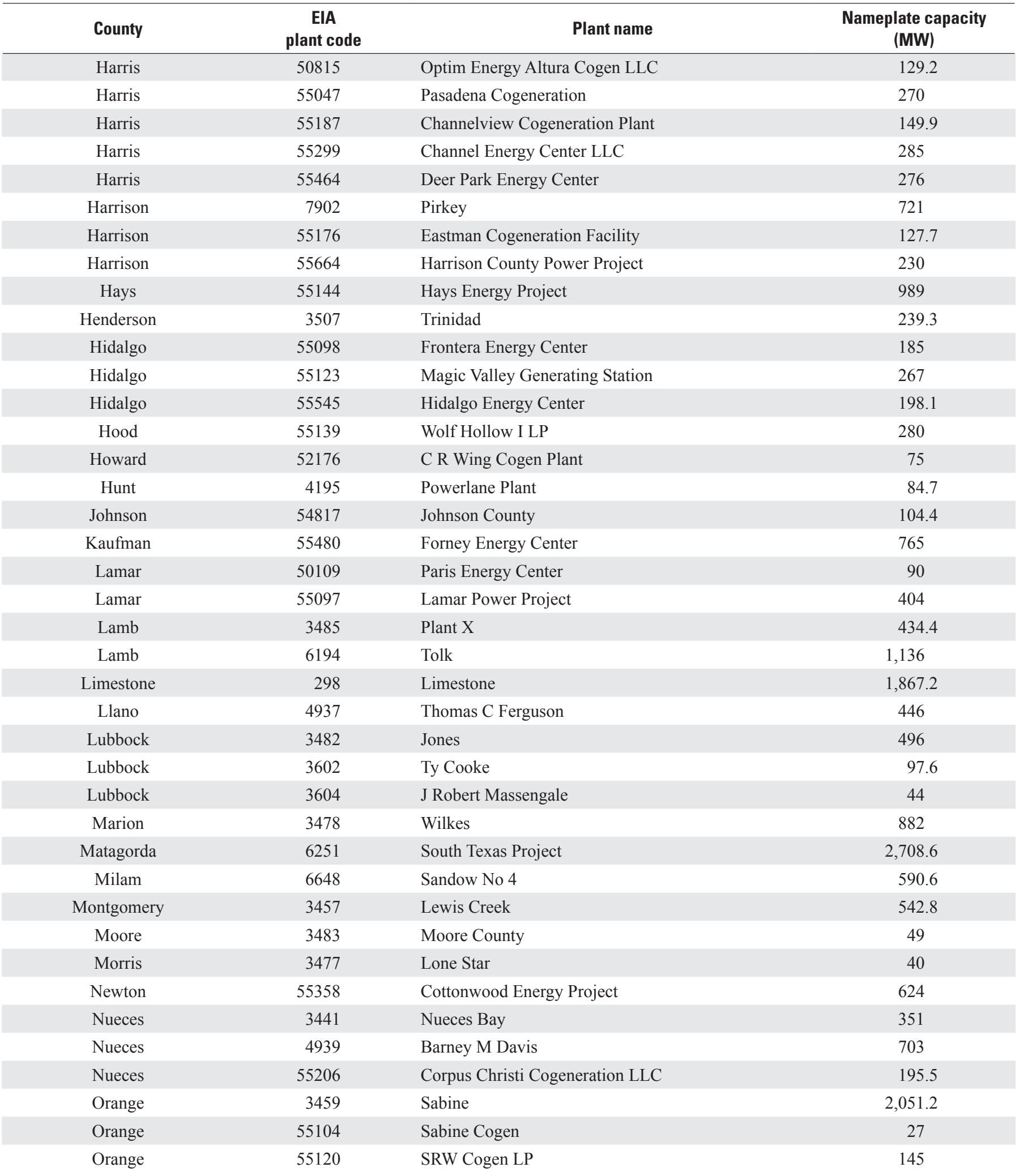


Appendix 1. The 1,284 thermoelectric plants one megawatt nameplate capacity or greater with water-cooling systems in the United States, 2010.-Continued

[EIA, U.S. Department of Energy, Energy Information Administration; MW, megawatt; initials associated with a power plant are part of the plant name, and not spelled out; --, nameplate capacity is not reported for the steam side of the combined-cycle power plant]

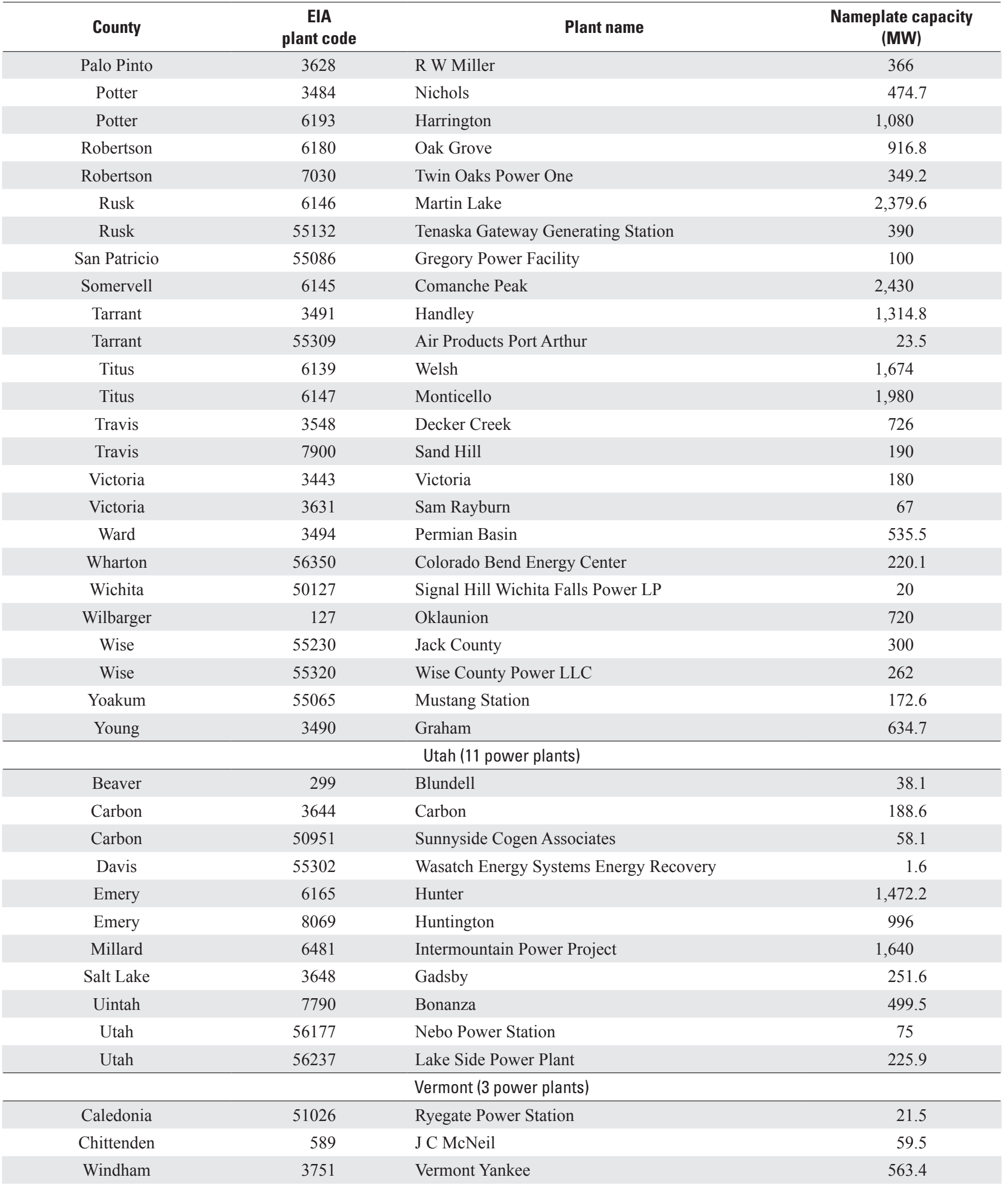


Appendix 1. The 1,284 thermoelectric plants one megawatt nameplate capacity or greater with water-cooling systems in the United States, 2010.-Continued

[EIA, U.S. Department of Energy, Energy Information Administration; MW, megawatt; initials associated with a power plant are part of the plant name, and not spelled out; --, nameplate capacity is not reported for the steam side of the combined-cycle power plant]

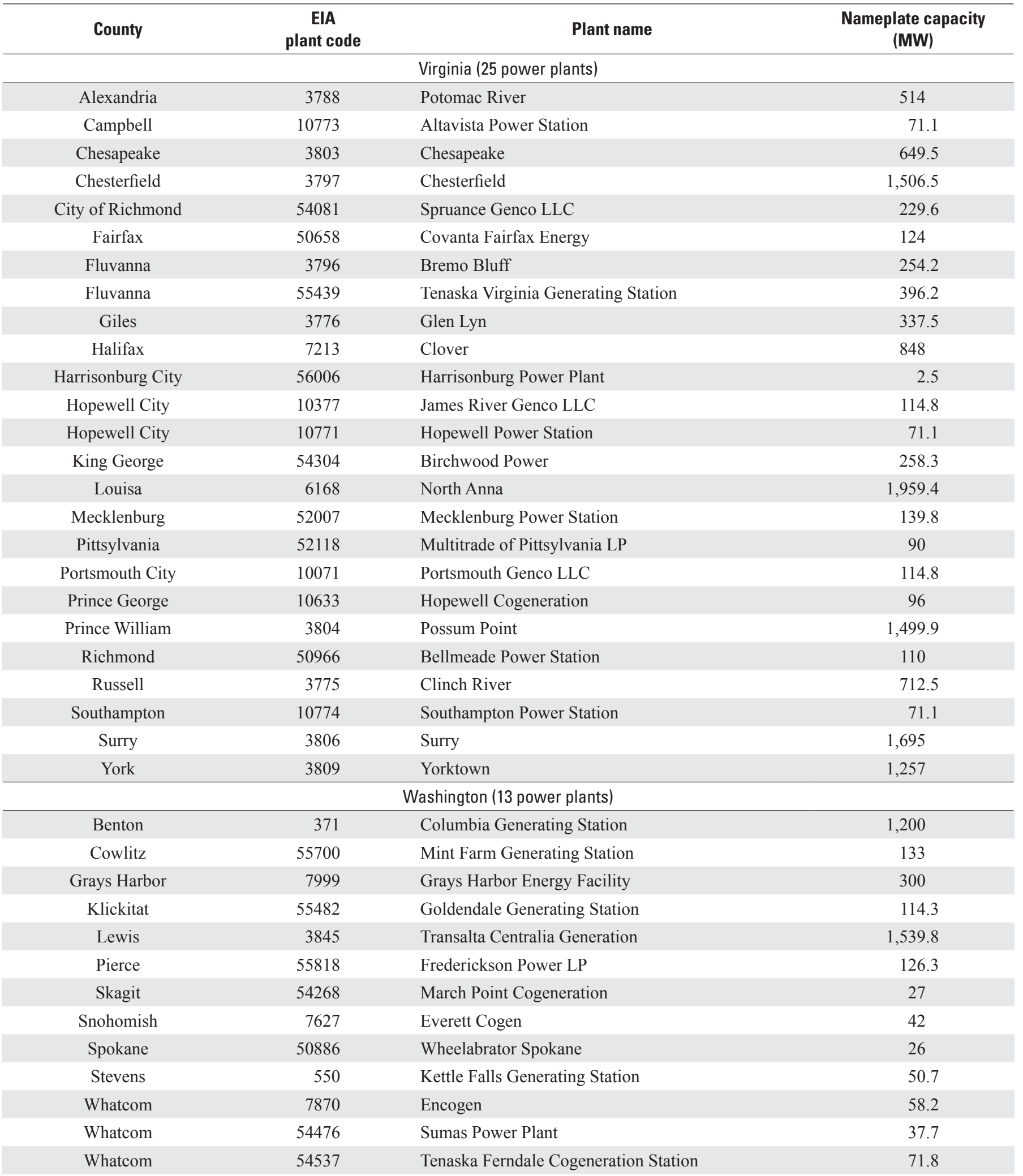


Appendix 1. The 1,284 thermoelectric plants one megawatt nameplate capacity or greater with water-cooling systems in the United States, 2010.-Continued

[EIA, U.S. Department of Energy, Energy Information Administration; MW, megawatt; initials associated with a power plant are part of the plant name, and not spelled out; --, nameplate capacity is not reported for the steam side of the combined-cycle power plant]

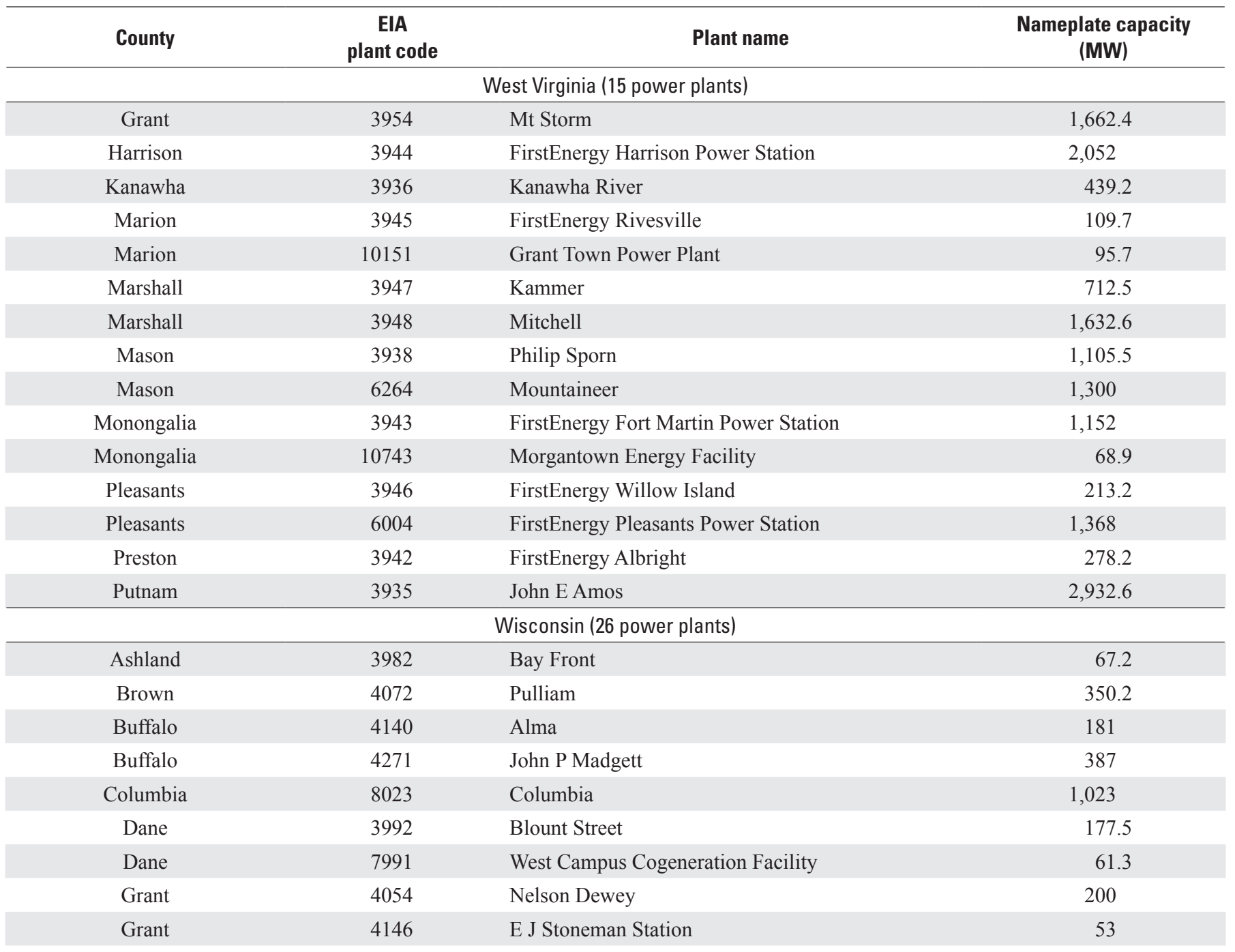


Appendix 1. The 1,284 thermoelectric plants one megawatt nameplate capacity or greater with water-cooling systems in the United States, 2010.-Continued

[EIA, U.S. Department of Energy, Energy Information Administration; MW, megawatt; initials associated with a power plant are part of the plant name, and not spelled out; --, nameplate capacity is not reported for the steam side of the combined-cycle power plant]

\begin{tabular}{|c|c|c|c|}
\hline County & $\begin{array}{c}\text { EIA } \\
\text { plant code }\end{array}$ & Plant name & $\begin{array}{c}\text { Nameplate capacity } \\
\text { (MW) }\end{array}$ \\
\hline Jefferson & 55011 & LSP-Whitewater LP & 106.2 \\
\hline Kewaunee & 8024 & Kewaunee & 560.1 \\
\hline La Crosse & 4005 & French Island & 30.4 \\
\hline Marathon & 4078 & Weston & $1,087.1$ \\
\hline Milwaukee & 4041 & South Oak Creek & $1,191.6$ \\
\hline Milwaukee & 4042 & Valley & 272 \\
\hline Milwaukee & 7549 & Milwaukee County & 11 \\
\hline Rock & 55641 & Riverside Energy Center & 299.7 \\
\hline Sheboygan & 4050 & Edgewater & 770 \\
\hline Vernon & 4143 & Genoa & 345.6 \\
\hline Winnebago & 4127 & Menasha & 28 \\
\hline \multicolumn{4}{|c|}{ Wyoming (8 power plants) } \\
\hline Albany & 6204 & Laramie River Station & 1,710 \\
\hline Campbell & 4150 & Neil Simpson & 21.7 \\
\hline Campbell & 7504 & Neil Simpson II & 80 \\
\hline Campbell & 56319 & Wygen 2 & 95 \\
\hline
\end{tabular}


Appendix 2. Guide to data contained in the U.S. Department of Energy, Energy Information Administration (EIA) 2010 Annual Electric Generator Data, Form-860, and the 2010 Power Plant Operations Report, Form ElA-923, used for the classification of thermoelectric plants and consumption estimation model input.

Evaporation at thermoelectric plants depends on the method by which electricity is generated (generation type) and the method by which waste heat is transferred to the atmosphere (cooling-system type). Because generation type and cooling-system type vary independently of one another and represent two distinct stages in the overall process of thermoelectric water consumption, it is useful to consider them separately. Such consideration leads to a two-tiered classification of thermoelectric plants that provides the analytical framework for the estimation methods presented in this report.

Appendix 2, table 1 shows the data fields used in the classification scheme and consumption estimation model from the 2010 Annual Electric Generator Data database, which is the repository for data from Form EIA-860, and the 2010 Power Plant Operations Report, which is the repository for data from Form EIA-923. The Description column describes the corresponding field name in Field Name; Form, data field source, either Form EIA-860 or Form EIA-923; File, database spreadsheet name, see file names below; Tab, spreadsheet tab associated with a corresponding spreadsheet file; Field Name, field name descriptor. Accessed on August 7, 2013 at http://www.eia.gov/electricity/data/eia860/index.html and http://www.eia.gov/electricity/data/ eia923/.

Survey Form EIA-860 collects generator-level specific information about existing and planned generators and associated environmental equipment at electric power plants with one megawatt or greater of combined nameplate capacity. Survey Form EIA-923 collects detailed electric power data - monthly and annually — on electricity generation, fuel consumption, fossil fuel stocks, and receipts at the power plant and prime mover level. Data fields shown in Appendix 2, table 1 are grouped by power plant technology type — generator, boiler, flue gas desulfurization, and cooling system — and by plant characteristics and boilerunit associations.

Selected Form EIA-860 survey files and tabs:

- LayoutY2010 - Provides a directory of all (published) data elements collected on the Form EIA-860 together with the related description, specific file location(s), and, where appropriate, an explanation of codes (Appendix 2, tables 1-4).

- GeneratorY2010 - Contains generator-level data for the surveyed generators, split into three tabs. The Exist tab includes those generators that are currently operating, out of service, or on standby.

- PlantY2010 - Contains plant-level data for the generators surveyed in all available years.

- EnviroAssocY2010 - Contains boiler association data for the environmental equipment data collected on the Form EIA-860. The Boiler_Gen identifies which boilers are associated with each generator; the Boiler_Cool tab shows which cooling systems are associated with each boiler.

- EnviroEquipY2010 - Contains environmental equipment data for the surveyed generators. The Boiler tab collects boiler data as collected on Schedule 6, Parts B, and C of the Form EIA-860; the Cooling tab collects cooling system data as collected on Schedule 6, Part F; the FGD tab collects FGD data as collected on Schedule 6, Part H.

Specific Form EIA-923 survey files and tabs:

- EIA923 SCHEDULES 2_3_4_5 Final 2010 — contains monthly and annual operational data as collected on Schedules 2, 3, 4, and 5. Tab Page 1 Generation and Fuel Data contains the quantity of fuel consumed, the heat content of fuels, and the net generation of electricity data as collected on Schedules 3 and 5, parts A. Tab Page 3 Boiler Fuel Data contains the quantity of fuel consumed in the boiler and the heat, sulfur, and ash content of the fuels for steam-electric, organic-fueled electric power plants as collected on Schedule 3, Part A.

- EIA923 SCHEDULE 3A 5A 8A 8B 8C 8D 8E 8F 2010 on NOV 302011 -contains monthly and annual operational data as collected on Schedules 3, 5, and 8. Tab Cooling Operations contains monthly cooling water data that includes diversion, withdrawal, discharge, and consumption rates as well as water temperature data as collected on Schedule 8, Part D. Tab FGD Operations contains annual FGD data as collected on Schedule 8, Part F.

Appendix 2, tables 2, 3, and 4 detail the codes and descriptions of the specific prime mover technologies and energy sources by generator type, and the cooling-system types contained in the files and tabs outlined in Appendix 2, table 1. 
Appendix 2. Table 1. Data used in the two-tiered classification system for thermoelectric plants and heat and water budget models to estimate water consumption from the 2010 Annual Electric Generator Data, EIA Form-860 and 2010 Power Plant Operations Report, Form EIA-923.

[EIA, U.S. Department of Energy, Energy Information Administration; FERC, Federal Energy Regulatory Commission; Btu, British thermal unit; blue highlighted field name detailed in Appendix 2, tables 2, 3, and 4]

\begin{tabular}{|c|c|c|c|c|}
\hline Description & Form & File & Tab & Field name \\
\hline \multicolumn{5}{|c|}{ Plant descriptors } \\
\hline EIA-assigned plant code & 860 and 923 & All files & All tabs & PLANT_CODE \\
\hline Name of plant & 860 and 923 & All files & All tabs & PLANT_NAME \\
\hline State location of plant & 860 and 923 & All files & All tabs & STATE \\
\hline $\begin{array}{l}\text { Combined heat and power system status of } \\
\text { the generator }\end{array}$ & 860 & GeneratorY2010 & Exist & COGENERATOR \\
\hline $\begin{array}{l}\text { FERC-qualifying cogenerator status of the } \\
\text { plant }\end{array}$ & 860 & PlantY2010 & & FERC_COGEN \\
\hline $\begin{array}{l}\text { North American Industry Classification } \\
\text { System (NAICS) code indicating the } \\
\text { primary purpose of the reporting plant }\end{array}$ & 860 & PlantY2010 & & PRIMARY_PURPOSE \\
\hline $\begin{array}{l}\text { Plant-level sector name and number, } \\
\text { designated by the plant's NAICS code, } \\
\text { regulatory status and FERC-cogen status }\end{array}$ & 860 & PlantY2010 & & $\begin{array}{l}\text { SECTOR_NAME and SEC- } \\
\text { TOR_NUMBER }\end{array}$ \\
\hline \multicolumn{5}{|c|}{ Generator technology } \\
\hline Generator identification code & 860 & GeneratorY2010 & Exist & GENERATOR_ID \\
\hline Operating status of the generator & 860 & GeneratorY2010 & Exist & STATUS \\
\hline $\begin{array}{l}\text { Prime mover code (turbine that converts } \\
\text { the energy in heated gases to mechanical } \\
\text { energy) }\end{array}$ & 860 & GeneratorY2010 & Exist & PRIME_MOVER \\
\hline $\begin{array}{l}\text { The generator nameplate capacity in } \\
\text { megawatts }\end{array}$ & 860 & GeneratorY2010 & Exist & NAMEPLATE \\
\hline Fuels used to power the generator & 860 & GeneratorY2010 & Exist & ENERGY_SOURCE \\
\hline $\begin{array}{l}\text { Net generation of electricity in megawatt } \\
\text { hours (MWh) per month and for the } \\
\text { year. Note: This is total electrical output } \\
\text { net of station service. In the case of com- } \\
\text { bined heat and power plants, this value } \\
\text { is intended to include internal consump- } \\
\text { tion of electricity for the purposes of a } \\
\text { production process, as well as power put } \\
\text { on the grid. }\end{array}$ & 923 & $\begin{array}{l}\text { EIA923 SCHEDULES } \\
\text { 2_3_4_5 Final } 2010\end{array}$ & $\begin{array}{l}\text { Page } 1 \text { Generation } \\
\text { and Fuel Data }\end{array}$ & Electricity Net Generation \\
\hline \multicolumn{5}{|c|}{ Boiler Technology } \\
\hline Boiler identification code & 860 & EnviroEquipY2010 & Boiler & BOILER_ID \\
\hline Operating status of the boiler & 860 & EnviroEquipY2010 & Boiler & BOILER_STATUS \\
\hline Fuels used to power the boiler & 860 & EnviroEquipY2010 & Boiler & PRIMARY_FUEL \\
\hline $\begin{array}{l}\text { Boiler efficiency when burning at } 100 \\
\text { percent load (nearest } 0.1 \text { percent) }\end{array}$ & 860 & EnviroEquipY2010 & Boiler & $\begin{array}{l}\text { EFFICIENCY_100_PCT } \\
\quad \text { LOAD }\end{array}$ \\
\hline $\begin{array}{l}\text { Boiler efficiency when burning at } 50 \\
\text { percent load (nearest } 0.1 \text { percent) }\end{array}$ & 860 & EnviroEquipY2010 & Boiler & $\begin{array}{l}\text { EFFICIENCY_50_PCT } \\
\text { LOAD }\end{array}$ \\
\hline
\end{tabular}


Appendix 2. Table 1. Data used in the two-tiered classification system for thermoelectric plants and heat and water budget models to estimate water consumption from the 2010 Annual Electric Generator Data, EIA Form-860 and 2010 Power Plant Operations Report, Form EIA-923.-Continued

[EIA, U.S. Department of Energy, Energy Information Administration; FERC, Federal Energy Regulatory Commission; Btu, British thermal unit; blue highlighted field name detailed in Appendix 2, tables 2, 3, and 4]

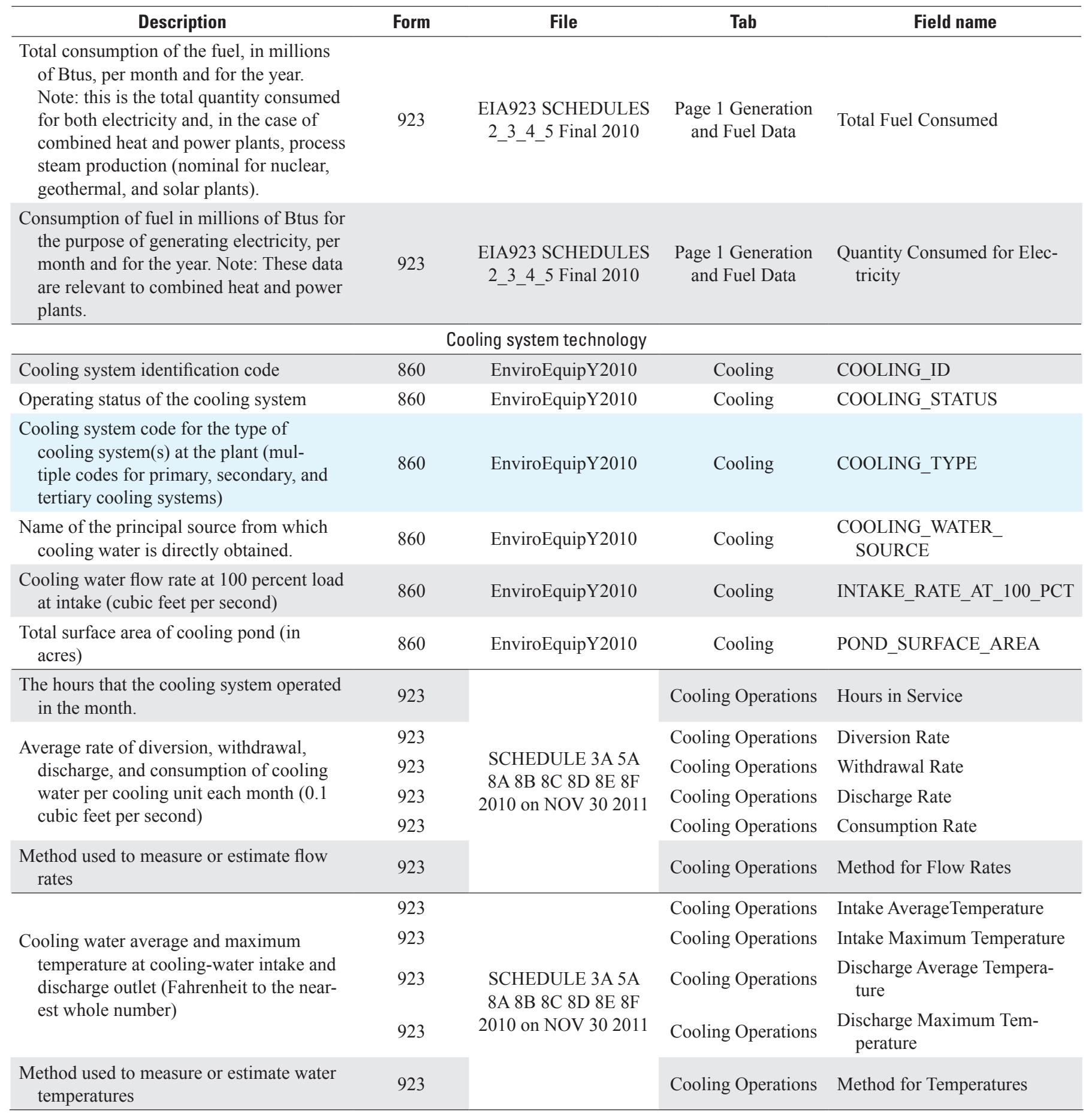


Appendix 2. Table 1. Data used in the two-tiered classification system for thermoelectric plants and heat and water budget models to estimate water consumption from the 2010 Annual Electric Generator Data, ElA Form-860 and 2010 Power Plant Operations Report, Form EIA-923.-Continued

[EIA, U.S. Department of Energy, Energy Information Administration; FERC, Federal Energy Regulatory Commission; Btu, British thermal unit; blue highlighted field name detailed in Appendix 2, tables 2, 3, and 4]

\begin{tabular}{|c|c|c|c|c|}
\hline Description & Form & File & Tab & Field name \\
\hline \multicolumn{5}{|c|}{ Flue gas desulfurization (FGD) technology } \\
\hline $\begin{array}{l}\text { Flue gas desulfurization (FGD) unit } \\
\text { identification code }\end{array}$ & 923 & $\begin{array}{l}\text { SCHEDULE 3A 5A } \\
\text { 8A 8B 8C 8D 8E } 8 \mathrm{~F}\end{array}$ & FGD Operations & FGD ID \\
\hline Operating status of the FGD unit & 923 & 2010 on NOV 302011 & FGD Operations & FGD Unit Status \\
\hline $\begin{array}{l}\text { FGD unit code for the type of FGD unit } \\
\text { used }\end{array}$ & 860 & EnviroEquipY2010 & FGD & FGD_TYPE \\
\hline $\begin{array}{l}\text { Type of fuel used for generation. Only } \\
\text { certain fuels are associated with FGD } \\
\text { systems. }\end{array}$ & 923 & $\begin{array}{l}\text { EIA923 SCHEDULES } \\
\text { 2_3_4_5 Final } 2010\end{array}$ & $\begin{array}{c}\text { Page } 3 \text { Boiler Fuel } \\
\text { Data }\end{array}$ & Reported Fuel Type Code \\
\hline \multicolumn{5}{|c|}{ Boiler unit associations } \\
\hline EIA-assigned plant code & 860 & EnviroAssocY2010 & $\begin{array}{l}\text { Boiler_Gen; and, } \\
\text { Boiler_Cool }\end{array}$ & PLANT_CODE \\
\hline $\begin{array}{l}\text { Boiler identification code; this database } \\
\text { provides tables that associate plant boiler } \\
\text { units with their paired generator and } \\
\text { cooling system units. }\end{array}$ & 860 & EnviroAssocY2010 & $\begin{array}{l}\text { Boiler_Gen; and, } \\
\text { Boiler_Cool }\end{array}$ & BOILER_ID \\
\hline Generator identification code & 860 & EnviroAssocY2010 & Boiler_Gen & GENERATOR_ID \\
\hline $\begin{array}{l}\text { Code indicating whether the boiler and } \\
\text { generator associations during the year } \\
\text { were actual }(\mathrm{A}) \text { or theoretical }(\mathrm{T}) \text {. }\end{array}$ & 860 & EnviroAssocY2010 & Boiler_Gen & $\begin{array}{l}\text { GENERATOR_ASSOCIA- } \\
\text { TION }\end{array}$ \\
\hline Cooling system identification code & 860 & EnviroAssocY2010 & Boiler_Cool & COOLING_ID \\
\hline
\end{tabular}

Appendix 2. Table 2. Prime mover types used to classify plants according to generation type [U.S. Department of Energy, Energy Information Administration (EIA), 2010 Annual Electric Generator Report, LayoutY2010. See Appendix 2, table 1, Generator Technology, PRIME_MOVER].

[Prime mover is the turbine that converts the energy in heated gases to mechanical energy.]

\begin{tabular}{|c|c|}
\hline \multirow{2}{*}{ ElA prime mover code } & Generation type \\
\hline & Prime mover description \\
\hline \multicolumn{2}{|r|}{ Combustion steam, nuclear, geothermal, solar thermal } \\
\hline \multicolumn{2}{|r|}{ Combined cycle } \\
\hline $\mathrm{CA}$ & Combined cycle steam part \\
\hline $\mathrm{CT}$ & Combined cycle combustion turbine part \\
\hline \multicolumn{2}{|r|}{ Geothermal } \\
\hline BT & Turbines used in a binary cycle \\
\hline
\end{tabular}


Appendix 2. Table 3. Energy sources used to classify plants by generation type [U.S. Department of Energy, Energy Information Administration (EIA), 2010 Annual Electric Generator Report, LayoutY2010. See Appendix 2, table 1, Generator Technology, ENERGY_ SOURCE].

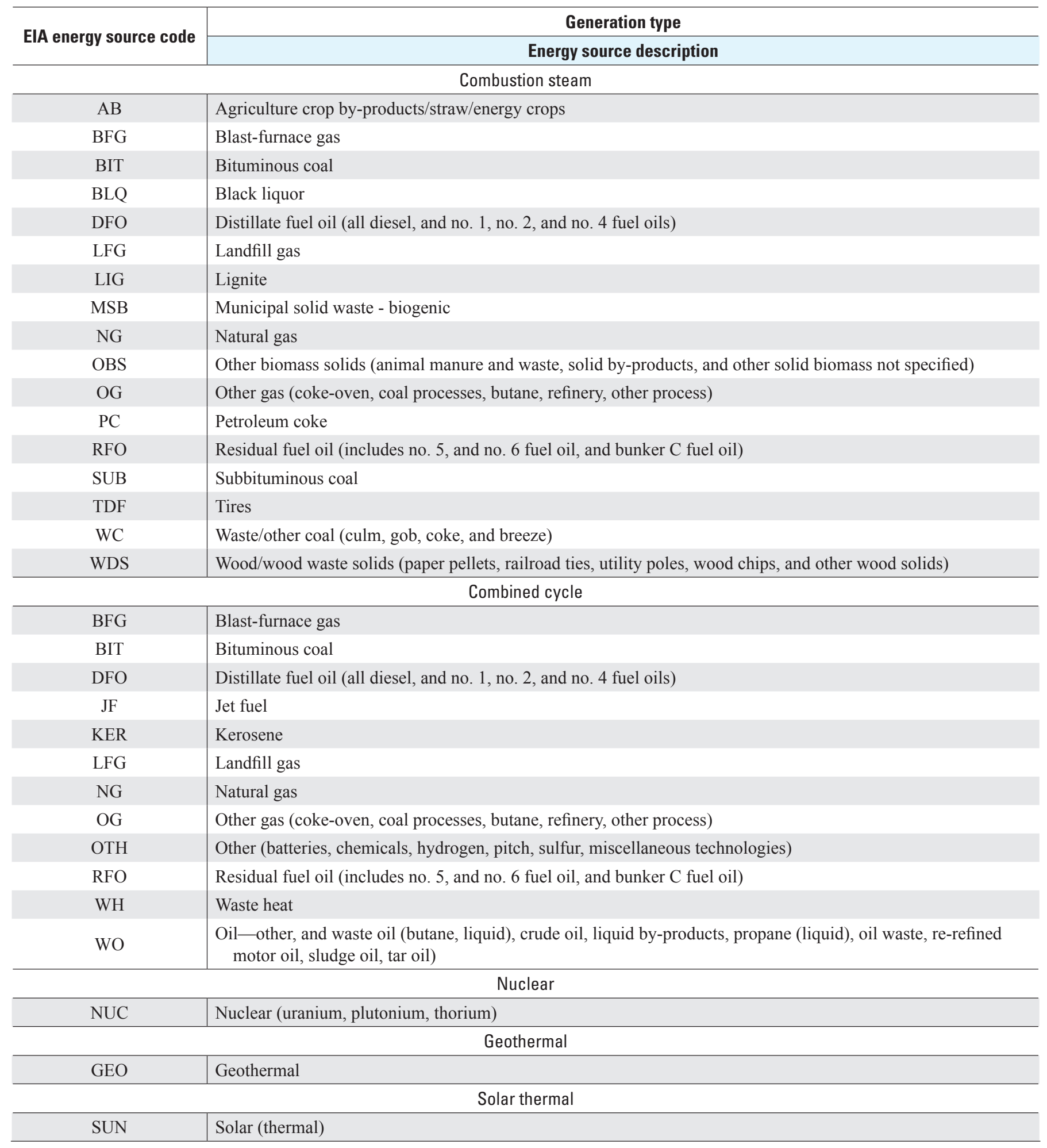


Appendix 2. Table 4. Cooling-sytem types used to classify plants by cooling system technology [U.S. Department of Energy, Energy Information Administration (EIA), 2010 Annual Electric Generator Report, LayoutY2010. See Appendix 2, table 1, Cooling System Technology, COOLING_TYPE].

\begin{tabular}{|c|c|}
\hline \multirow{2}{*}{ EIA cooling type code } & \multirow{2}{*}{ Cooling-system type } \\
\hline & \\
\hline \multicolumn{2}{|r|}{ Dry (air) cooling system } \\
\hline $\mathrm{DC}$ & Air cooling systems \\
\hline \multicolumn{2}{|r|}{ Hybrid cooling systems } \\
\hline $\mathrm{HRC}$ & Hybrid: recirculating cooling pond(s) or canal(s) with dry cooling \\
\hline HRF & Hybrid: recirculating with forced draft cooling tower(s) with dry cooling \\
\hline HRI & Hybrid: recirculating with induced draft cooling tower(s) with dry cooling \\
\hline \multicolumn{2}{|r|}{ Once-through cooling systems } \\
\hline $\mathrm{OC}$ & Once through with cooling pond(s) or canal(s) \\
\hline OF & Once through, freshwater \\
\hline OS & Once through, saline water \\
\hline \multicolumn{2}{|r|}{ Recirculating cooling systems } \\
\hline $\mathrm{RC}$ & Recirculating with cooling pond(s) or canal(s) \\
\hline $\mathrm{RF}$ & Recirculating with forced draft cooling tower(s) \\
\hline RI & Recirculating with induced draft cooling tower(s) \\
\hline $\mathrm{RN}$ & Recirculating with natural draft cooling tower(s) \\
\hline \multicolumn{2}{|r|}{ Other cooling system } \\
\hline OT & Other \\
\hline
\end{tabular}


Appendix 3. Databases accessed for thermoelectric plant classification and modeling data.

ECHO is the U.S. Environmental Protection Agency’s Enforcement \& Compliance History Online database. ECHO contains location latitude/longitude coordinates in decimal degrees for power plants with regulated water discharge data. ECHO database water data come from two data sets: the Permit Compliance System (PCS) for Clean Water Act permitted dischargers (under the National Pollutant Discharge Elimination System, or NPDES), and the Integrated Compliance Information System (ICIS) for Clean Water Act permitted dischargers (under the NPDES). Accessed January 22, 2013 at http://www.epa-echo.gov/echo.

eGRID is the U.S. Environmental Protection Agency's Emissions \& Generation Resource Integrated Database. The eGRID database provides data on electric generation and air emissions of U.S. power plants and includes plant locations in latitude/ longitude decimal degrees. Accessed January 22, 2013 at http://www.epa.gov/cleanenergy/energy-resources/egrid/index. html\#download.

Form EIA-860 is the Department of Energy's Energy Information Administration electricity database for the Annual Electric Generator Report. The database provides generator-level information on existing and proposed generators and includes design parameter data on associated environmental equipment. Accessed January 29, 2013 at http://www.eia.gov/electricity/data/ eia860/index.html.

Form EIA-923 is the Department of Energy's Energy Information Administration electricity database for the Power Plant Operations Report. The database provides monthly and annual operational data on electricity generation, fuel consumption, and environmental equipment. Accessed January 29, 2013 at http://www.eia.gov/electricity/data/eia923/.

GLSEA2 is the National Oceanic and Atmospheric Administration's Great Lakes Surface Environmental Analysis, which is a daily digitial map of lake surface temperatures and ice cover that is produced by the Great Lakes Environmental Research Laboratory. Accessed March 8, 2013, at http://coastwatch.glerl.noaa.gov/glsea/doc/.

HSIP Gold is the Department of Homeland Security's Homeland Security Infrastructure Program database. The HSIP provides power plant information from several databases including latitude and longitude coordinates. Accessed January 24, 2013 at https://www.hifldwg.org/public/HSIP\%20Gold\%20Freedom\%20One\%20Pager_July\%202012.pdf.

NEEDS is the National Electric Energy Data System database, and it contains the generation unit records used to construct the "model" plants that represent existing and planned/committed units in USEPA modeling applications of the Integrated Planning Model (IPM). NEEDS includes basic geographic, operating, air emissions, and other data on these generating units. NEEDS was completely updated for Base Case v.4.10. For a description of the sources used in preparing NEEDS v.4.10, see Base Case v.4.10 Documentation, Chapter 4: Generating Resources. Accessed August 1, 2013 at http://www.epa.gov/airmarkt/progsregs/ epa-ipm/BaseCasev410.html\#needs.

NETL-CPPDB is the Department of Energy's National Energy Technology Laboratory, Coal Power Plant Database. NETL's CPPDB provides electric generation and emissions information for all coal power plants in the U.S. and includes locations in latitude/longitude decimal degrees. Accessed January 13, 2013 at http://www.netl.doe.gov/energy-analyses/hold/technology.html.

NHDPlus is an integrated suite of application-ready geospatial data products, incorporating many of the best features of the National Hydrography Dataset (NHD), the National Elevation Dataset (NED), and the National Watershed Boundary Dataset (WBD). NHDPlus includes a stream network based on the medium resolution NHD (1:100,000 scale), improved networking, feature naming, and "value-added attributes" (VAA). NHDPlus also includes elevation-derived catchments produced using a drainage enforcement technique. This technique involves enforcing the 1:100,000-scale NHD drainage network by modifying the NED elevations to fit with the network via trenching and using the WBD, where certified WBD is available, to enforce hydrologic divides. The resulting modified digital elevation model (DEM) was used to produce hydrologic derivatives that closely agree with the NHD and WBD. An interdisciplinary team from the U.S. Geological Survey (USGS) and the U.S. Environmental Protection Agency (USEPA) found this method to produce the best-quality agreement among the ingredient datasets among the various methods tested. Accessed January 29, 2013 at http://www.horizon-systems.com/NHDPlus/NHDPlusV2_home. php.

NWIS is the U.S. Geological Survey's National Water Information System database. NWIS provides surface-water and groundwater resource data collected at streamgaging stations throughout the United States. It includes current and historical daily mean surface water temperature data. Accessed March 8, 2013, at http://waterdata.usgs.gov/nwis/sw.

QCLCD is the National Oceanic and Atmospheric Administration National Climatic Data Center, Quality Controlled Local Climatological Data database, and it consists of hourly, daily, and monthly summaries of meteorological observations. Accessed March 8, 2013, at http://www.ncdc.noaa.gov/land-based-station-data/quality-controlled-local-climatological-data-qclcd. QCLCD documentation accessed March 8, 2013, at http://cdo.ncdc.noaa.gov/qclcd/qclcddocumentation.pdf. 
Prepared by USGS West Trenton Publishing Service Center. Edited by Valerie M. Gaine.

Graphics and layout by Timothy W. Auer.

Sankey diagrams by Timothy H. Diehl.

For additional information, contact:

Eric J. Evenson

Coordinator-National Water Census

U.S. Geological Survey

3450 Princeton Pike, Suite 110

Lawrenceville, NJ 08648

or visit the National Water Census Web site at: http://water.usgs.gov/watercensus 


\section{$\frac{1}{80}$}

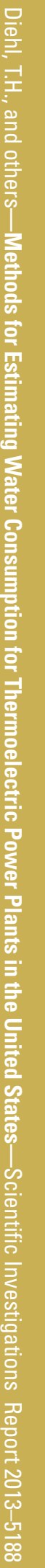

